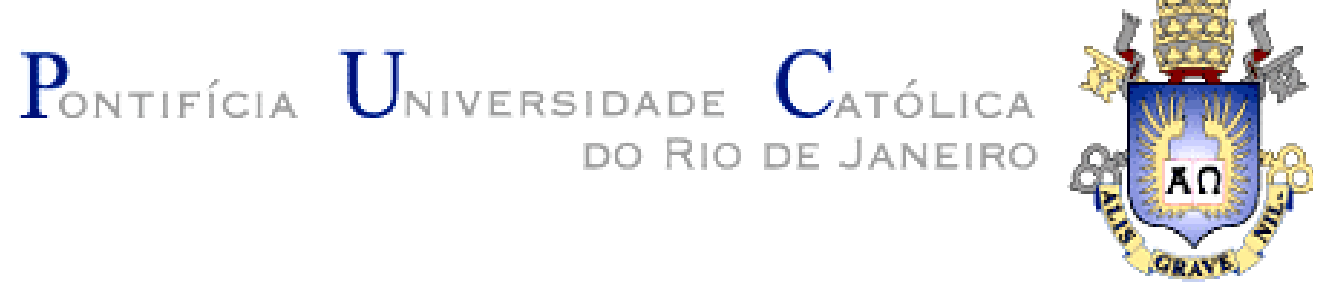

Dalila de Sousa Gomes

Simulador de escoamento em poços de produção de petróleo

Dissertação de Mestrado

Dissertação apresentada como requisito parcial para obtenção do título de Mestre pelo Programa de PósGraduação em Engenharia Mecânica da PUC-Rio.

Orientadora: Prof. a Monica Feijó Naccache. Co-Orientador: Prof. Wellington Campos

Rio de Janeiro

Agosto de 2015 


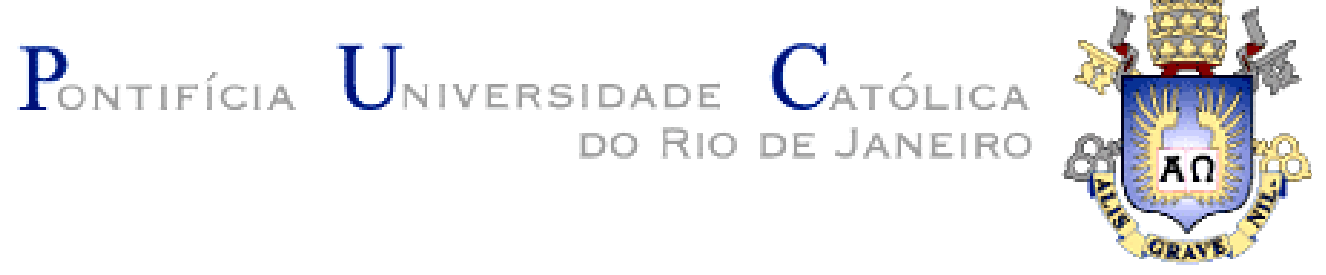

Dalila de Sousa Gomes

\title{
Simulador de escoamento em poços de produção de petróleo
}

\begin{abstract}
Dissertação apresentada como requisito parcial para obtenção do grau de Mestre pelo Programa de PósGraduação em Petróleo e Energia do Departamento de Engenharia Mecânica do Centro Técnico Científico da PUC-Rio. Aprovada pela Comissão Examinadora abaixo assinada.
\end{abstract}

Prof. Monica Feijó Naccache

Orientador

Departamento de Engenharia Mecânica - PUC-Rio

Prof. Wellington Campos

Co-Orientador

PETROBRAS

Prof. Eduardo dos Santos Radespiel

PETROBRAS

Prof. Paulo Roberto de Sousa Mendes

Departamento de Engenharia Mecânica - PUC-Rio

Prof. José Eugênio Leal

Coordenador Setorial do Centro

Técnico Cientifico - PUC-Rio

Rio de Janeiro, 13 de Agosto de 2015 
Todos os direitos reservados. É proibida a reprodução total ou parcial do trabalho sem autorização da universidade, do autor e do orientador.

\section{Dalila de Sousa Gomes}

Graduou-se em Engenharia Química na Pontifícia Universidade Católica do Rio de Janeiro (PUC-Rio), no Rio de Janeiro - RJ - Brasil, em 2012.

Ficha Catalográfica

Gomes, Dalila de Sousa

Simulador de escoamento em poços de produção de petróleo / Dalila de Sousa Gomes ; orientador: Monica Feijó Naccache ; co-orientador: Wellington Campos. 2015.

93 f. : il. (color.) ; $30 \mathrm{~cm}$

Dissertação (mestrado)-Pontifícia Universidade Católica do Rio de Janeiro, Departamento de Engenharia Mecânica, 2015.

Inclui bibliografia

1. Engenharia mecânica - Teses. 2. Escoamento multifásico. 3. Poços de petróleo. 4. Simulação numérica. 5. Programação. I. Naccache, Monica Feijó. II. Campos, Wellington. III. Pontifícia Universidade Católica do Rio de Janeiro. Departamento de Engenharia Mecânica. IV. Título. 


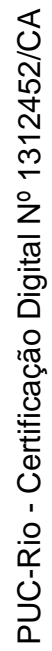

Ao meu filho, Matheus Gomes. 


\section{Agradecimentos}

Agradeço ao CNPq.

Agradeço à minha orientadora Prof ${ }^{\mathrm{a}}$. Mônica Feijó Naccache que foi sempre muito atenciosa e prestativa. Sou muito grata pelo apoio, orientação e por contribuir de maneira tão construtiva a esta obra acadêmica.

Agradeço ao meu orientador Wellington Campos, pela generosa orientação, pela paciência, pela dedicação e por me proporcionar enorme aprendizado, compartilhando comigo seu extenso conhecimento na área.

Agradeço aos meus familiares, em especial à minha tia Virgínia Prioste (em memória) pela valiosa ajuda ao longo de toda a minha vida, à minha mãe Joseline Ferreira pelo exemplo e incentivo e a meu querido pai, Hildebrando Gomes, que mesmo não estando mais entre nós ainda me inspira e me dá forças. Agradeço também aos meus primos Marcello Prioste pelo apoio, e Monica Prioste.

Um agradecimento especial ao meu amado companheiro Stanley Zvaig, que sempre me apoiou e contribuiu não só para este, mas para cada um dos meus projetos ao longo da última década. 
Por fim agradeço a todos os colegas e amigos que estiveram presentes no decorrer de todo o mestrado. Alguns antigos, outros novos, mas cada um contribuiu de forma especial para a realização desse projeto. Obrigada Felipe Lopes, Tania Metzger, Gisele Barbosa, Henrique Meira e Oliver Everett pelo apoio, amizade e companheirismo durante todos esses anos de PUC-Rio. Obrigada Rafael Feital e Rodrigo Pizarro pela enorme parceria e amizade. Obrigada Mario Pareto, Pedro Campos, Guilherme Bessa, Ester Girão, Maria Luiza Nerys, Izabel Souto, Lívia Tardelli, Nathália Passos e José Firmino, por terem tornado os dias de estudo no LCA mais leves e agradáveis, mesmo nos finais de semana em que ficávamos confinados estudando e vendo como o dia estava lindo lá fora. Um agradecimento especial às amigas Mariana Gonçalves, Mariana Heringer, Samara Amorim e Thayná Carneiro: amizade que começa na PUC não fica só na PUC mas se estende pra sempre. Aos amigos de longa data Clarice Ausquia, Pedro Henrique Malafaia e Emerson dos Santos que mesmo distante geograficamente sempre me deram muita força: vocês são incríveis. 


\section{Resumo}

Gomes, Dalila de Sousa; Naccache, Mônica Feijó; Campos, Wellington. Simulador de escoamento em poços de produção de petróleo. Rio de Janeiro, 2015. 93p. Dissertação de Mestrado - Departamento de Engenharia Mecânica, Pontifícia Universidade Católica do Rio de Janeiro.

Sistemas de escoamento multifásico se formam ao longo de um poço de produção de petróleo. A análise do comportamento do escoamento através da coluna de produção é realizada com o apoio de ferramentas computacionais e é essencial para o projeto e operação de um sistema de produção de petróleo. Os simuladores comerciais disponíveis para esse tipo de análise exigem aquisição de licença, cujo custo é elevado, restringindo seu uso às grandes companhias petrolíferas e aos renomados institutos de pesquisa. Além disso, esses programas não permitem a visualização da metodologia utilizada para o tratamento do problema físico e para a solução numérica empregada, e nem a alteração de parâmetros internos, tornando seu uso restrito a certas classes de problemas. Apesar da grande demanda e utilidade desse tipo de software ainda há poucos trabalhos desenvolvidos nessa área. Esta pesquisa tem como objetivo apresentar o desenvolvimento de um simulador de escoamento multifásico simplificado e aberto, com aplicação na otimização da produção de óleo e gás. Dentre as aplicações do programa podemos citar a obtenção das curvas de gradiente de pressão e a otimização de gás-lift. Um estudo paramétrico foi conduzido, mostrando a influência de parâmetros como, por exemplo, o diâmetro da tubulação. Os resultados obtidos foram comparados com a literatura e são fisicamente coerentes. Sendo assim, o programa desenvolvido mostra-se promissor.

\section{Palavras chave}

Escoamento multifásico; Poços de petróleo; simulação numérica; programação. 


\section{Abstract}

Gomes, Dalila de Sousa; Naccache, Mônica Feijó (Advisor); Campos, Wellington (Advisor). Multiphase flow simulator for oil production wells. Rio de Janeiro, 2015. 93p. M.Sc Thesis - Departamento de Engenharia Mecânica, Pontifícia Universidade Católica do Rio de Janeiro.

Multiphase flow systems are formed along an oil production well. The analysis of the flow behavior through the production column is performed with the aid of computational tools, and is very important to the design and optimization of the oil well production operation. In general, the commercial softwares available to analyze this process are very expensive, which restrict its use to some particular companies. In addition, the methodology used to analyze the physical problem, and the numerical solution are fixed and closed, which restrict its use to certain classes of problems, since it is not possible to change or improve the numerical solution. Despite the great demand and use of this kind of software, there are few researches in this area. This research aims to present the development of a simplified multiphase flow simulator open to public, with application to the optimization of oil and gas production wells. Among the applications are the plot of pressure-distribution curves and the optimization of gas-lift. A parametric study is performed, showing the influence of some governing parameters, such as tubing diameter, in the production flow rate. The results obtained were compared with pertinent literature and are physically reasonable, showing that the software developed is promising.

\section{Keywords}

Multiphase flow; Oil well; Numerical simulation; programming. 


\section{Sumário}

1 Introdução 16

1.1. Motivação 16

1.2. Objetivo 16

$\begin{array}{ll}\text { 1.3. Considerações gerais } & 17\end{array}$

1.4. Revisão bibliográfica 19

2 Conceitos fundamentais $\quad 22$

2.1. Padrões de escoamento 22

2.2. O Enfoque correlacional 24

2.3. Curvas de IPR e TPR 27

2.4. Curvas de gradientes de pressão 28

2.5. Gás lift 31

2.6. Modelo Black Oil 33

3 Modelagem $\quad 35$

3.1. Metodologia 35

3.2. Modelo matemático 39

3.2.1. Considerações gerais 39

3.2.2. Cálculo das propriedades 40

3.3. Modelo Computacional 58

$\begin{array}{ll}\text { 3.4. Validação do programa } & 60\end{array}$

4 Análise dos resultados $\quad 64$

4.1. Curvas de gradiente de pressão 64

4.2. Determinação da pressão no fundo do poço $\left(p_{w f}\right) 66$

4.3. Obtenção das curvas de IPR, TPR e vazão de produção do poço 66

4.4. Influência da pressão do reservatório na vazão de produção 67

4.5. Determinação da RGL ótima e vazão de injeção de gás 68

4.6. Influência do diâmetro da coluna na vazão de produção 71

4.7. Determinação da pressão na cabeça do poço 72 
5 Conclusão

6 Referências Bibliográficas 


\section{Lista de figuras}

Figura 1 - Esquema de produção....................................................................... 19

Figura 2 - Exemplo de mapa de regime de escoamento de uma mistura...............22

Figura 3 - Evolução do escoamento de uma corrente de líquido em uma tubulação (Brennen, 2005).

Figura 4 - Determinação da $p_{\mathrm{wf}}$ a partir de uma curva de distribuição

de pressão para um escoamento bifásico.

Figura 5-Validação experimental da curvatura reversa em curvas de

distribuição de pressão, à baixas pressões (Baxendell e Thomas, 1961). .............. 30

Figura 6- Ilustração simplificada de um Sistema de gás lift .................................. 33

Figura 7 - Esquema de poço utilizado para desenvolver o simulador.

$\mathrm{Pt}=$ pressão na cabeça do poço; $\mathrm{p}_{\mathrm{wf}}=$ pressão no fundo do poço;

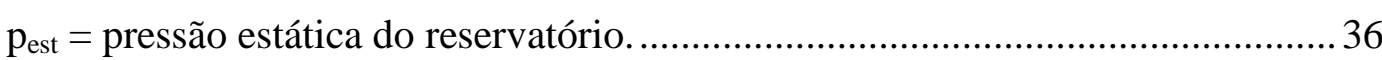

Figura 8- Representação da discretização da coluna de produção ......................... 37

Figura 9-Gráfico para obtenção do adimensional $\mathrm{C}_{\mathrm{NL}}$

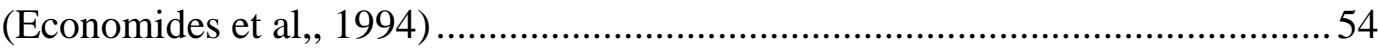

Figura 10 - Gráfico para obtenção de $H L \Psi$ (Economides et al., 1994) ................ 55

Figura 11- Gráfico para obtenção de $\Psi$ (Economides et al,, 1994) .......................56

Figura 12 - Interface com o simulador: dados de entrada...................................59

Figura 13 - Interface com o programa: botão de start e resultados........................60

Figura 14- (a) Curvas de gradiente de pressão obtidas pelo simulador

desenvolvido (b) Curvas de Gilbert para comparação reproduzido de

Gilbert (1954)

Figura 15- Curvas de gradiente de pressão obtidas pela simulação nas

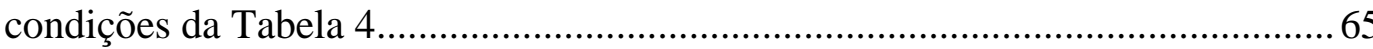

Figura 16- Curvas de IPR e TPR para as condições da Tabela 4......................... 67

Figura 17- Curvas de IPR e TPR para as condições da Tabela 5 ........................ 68

Figura 18-Curva de IPR e TPR para diversas RGLs .......................................... 70

Figura 19 - Detalhe da Figura 18, onde é possível visualizar que as

curvas se cruzam. A curva correspondente à RGL=1100 scf/STBO

intercepta a curva e IPR de forma a produzir com a maior vazão. 
Figura 20 - Curva de IPR e TPR para RGL = 1100 scf/STBO. ......................... 71

Figura 21- Influência do diâmetro da coluna na vazão de produção...................... 72

Figura 22 - Curvas obtidas para as condições da Tabela 6, com a

versão 2

\section{Lista de tabelas}

Tabela 1 - Informações sobre variáveis que são dados de entrada

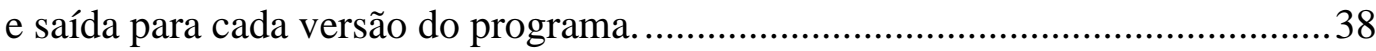

Tabela 2 - Dados de entrada para a simulação para comparação com as ..............61

Tabela 3- Comparação entre as pressões encontradas pelo simulador ..................62

Tabela 4 - Dados de entrada da simulação.............................................................64

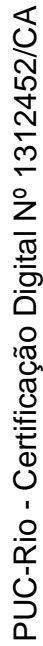

Tabela 5- Dados de entrada para a simulação, com alteração ..............................67

Tabela 6 - Condições da simulação com a versão 2 do programa. .........................72 


\title{
Abreviações
}

bbl - Barrel (barril de óleo)

IPR - Inflow Performance Relationship

RGO - Razão gás-óleo, scf/STBO

RGL - Razão gás-líquido, scf/STBO

STBO - Stock tank barrel oil

scf - standard cubic foot

TPR - Tubing Performance Relationship

VBA - visual basic for applications

\section{Nomenclaturas}

\author{
A - Área transversal do escoamento \\ $\mathrm{B}_{\mathrm{g}}-$ Fator volume de formação do gás, $\mathrm{ft}^{3} / \mathrm{STBO}$ \\ $\mathrm{B}_{\mathrm{o}}$ - Fator volume de formação do óleo, bbl/STBO \\ $\mathrm{d}$ - diâmetro interno da coluna, in \\ dp - passo de pressão, psia \\ e - rugosidade \\ $\mathrm{f}$ - fator de fricção \\ $\mathrm{f}_{\mathrm{w}}-$ fração de água \\ $\mathrm{g}$ - aceleração da gravidade, $32,2 \mathrm{ft} / \mathrm{s}^{2}$ \\ gc - constante gravitacional de transformação de unidades, 32,17 lbm.ft/(lbf.s ${ }^{2}$ ) \\ gn - gradiente de pressão, psi/ft \\ $\mathrm{H}_{\text {colu }}$ - altura da coluna de produção, $\mathrm{ft}$ \\ $\mathrm{H}_{\mathrm{L}}$ - Holdup de líquido com escorregamento (fração de líquido) \\ $\mathrm{J}$ - índice de produtividade do poço, bbl/dia/psia \\ $\mathrm{K}$ - rugosidade relativa \\ $\mathrm{M}_{\mathrm{g}}$ - massa molar do gás
}


$\mathrm{M}_{\mathrm{o}}$ - massa molar do óleo

$\mathrm{N}_{\mathrm{vl}}$ - liquid velocity number

$\mathrm{N}_{\mathrm{vg}}-$ gas velocity number

$\mathrm{N}_{\mathrm{D}}$ - pipe diameter number

$\mathrm{N}_{\mathrm{L}}$ - liquid viscosity number

p - pressão, psia

$\mathrm{p}_{\mathrm{b}}$ - pressão de bolha, psia

$\mathrm{p}_{\mathrm{pc}}-$ pressão pseudo crítica

$\mathrm{p}_{\mathrm{pr}}-$ pressão pseudo reduzida

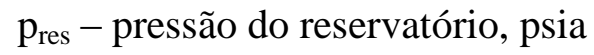

$\mathrm{p}_{\mathrm{t}}$ - pressão na cabeça do poço, psia

$\mathrm{p}_{\mathrm{wf}}$ - pressão de fundo em fluxo (pressão no fundo do poço)

Q - Vazão total de líquido (óleo e água), scf/dia

$\mathrm{Q}_{\mathrm{g}}$ - Vazão de gás, scf/dia

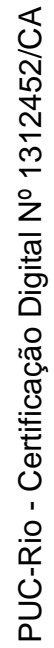

$\mathrm{Q}_{\mathrm{gst}}$ - vazão de gás na superfície, scf/dia

$\mathrm{Q}_{1}$ - Vazão de líquido, scf/dia

$Q_{\text {ost }}$ - vazão de óleo na superfície, scf/dia

$\mathrm{R}_{\mathrm{e}}$ - Número de Reynolds

$\mathrm{R}_{\mathrm{sb}}$ - Razão de solubilidade do gás no ponto de bolha, scf/STBO

$\mathrm{R}_{\mathrm{so}}$ - Razão de solubilidade do gás no óleo, scf/STBO

$\mathrm{T}$ - temperatura, ${ }^{\circ} \mathrm{F}$

$\mathrm{T}_{\mathrm{ini}}$ - temperatura nas condições iniciais da simulação

$\mathrm{T}_{\mathrm{pc}}$ - temperatura pseudo crítica

$\mathrm{T}_{\mathrm{pr}}$ - temperatura pseudo reduzida

$\mathrm{T}_{\text {res }}-$ Temperatura do reservatório, ${ }^{\circ} \mathrm{F}$

$\mathrm{v}$ - velocidade $\mathrm{ft} / \mathrm{s}$

$\mathrm{v}_{\mathrm{sl}}$ - velocidade superficial do líquido, $\mathrm{ft} / \mathrm{s}$

$\mathrm{v}_{\mathrm{sg}}$ - velocidade superficial do gás, $\mathrm{ft} / \mathrm{s}$

$\mathrm{v}_{\mathrm{sm}}$ - velocidade superficial da mistura, $\mathrm{ft} / \mathrm{s}$

$\mathrm{v}_{\mathrm{m}}$ - velocidade da mistura, $\mathrm{ft} / \mathrm{s}$

$\mathrm{Z}$ - fator de compressibilidade do gás

$\gamma_{\mathrm{g}}$ - densidade relativa do gás

$\gamma_{0}$ - densidade relativa do óleo

$\rho_{\mathrm{g}}-$ massa específica do gás 
$\rho_{\mathrm{o}}-$ massa específica do óleo

$\rho_{\mathrm{ar}}-$ massa específica do ar

$\rho_{\mathrm{m}}-$ massa específica da mistura

$\mu_{\mathrm{do}}-$ viscosidade do óleo morto

$\mu_{\mathrm{o}}$ - viscosidade do óleo vivo

$\mu_{\mathrm{g}}$ - viscosidade do gás

$\sigma$ - tensão superficial

$\lambda_{\mathrm{L}}$ - holdup de líquido sem escorregamento

$\lambda_{\mathrm{g}}$ - holdup de gás sem escorregamento 


\section{Introdução}

\section{1. Motivação}

Sistemas de escoamento multifásico se formam ao longo de uma coluna de produção de petróleo. Esses sistemas são bastante complexos e uma boa estimativa (confiável) de seu comportamento é essencial para o projeto e operação de sistemas de produção offshore (Danielson et. al, 2000).

Simuladores numéricos são ferramentas essenciais para a produção de óleo e gás, pois fornecem uma boa estimativa do comportamento do escoamento ao longo da coluna, permitindo assim, um melhor planejamento do projeto e dos equipamentos envolvidos na atividade de produção, bem como a otimização da vazão de produção.

Atualmente, existem alguns simuladores comerciais, mas esses simuladores não são abertos ao público, exigindo aquisição de licença, cujo custo é elevado. Logo, seu uso é bastante restrito as grandes companhias petrolíferas e aos renomados institutos de pesquisa. Além disso, esses programas não permitem a visualização da metodologia utilizada para o tratamento do problema físico e para a solução numérica empregada, e nem a alteração de parâmetros internos, tornando seu uso restrito a certas classes de problemas. Apesar da grande demanda e utilidade desse tipo de software ainda há poucos trabalhos desenvolvidos nessa área.

\section{2.}

Objetivo

Apresentar o desenvolvimento do simulador de escoamento multifásico em poços de petróleo simplificado e aberto. Fazer um estudo paramétrico, analisando as aplicações e resultados. 


\section{3.}

\section{Considerações gerais}

O escoamento multifásico ocorre em várias etapas da produção de hidrocarbonetos. O escoamento multifásico consiste no escoamento simultâneo de duas ou mais fases. As fases podem ser líquidas (água, óleo), sólidas (areia, pedras) ou gasosas (gás natural, ar). A presença dessas diferentes fases coexistindo no poço e nos dutos em geral, pode causar instabilidades no escoamento que podem afetar a vazão de produção ou danificar equipamentos (Gryzlov, 2011).

Os principais dados para o estudo de sistemas multifásicos são: (a) as propriedades físicas de cada fase; (b) a geometria do sistema de escoamento; (c) as condições de contorno. O objetivo é calcular a distribuição de pressão ao longo do duto. Na literatura é possível encontrar diversas abordagens para a determinação da perda de carga e do regime de escoamento como, por exemplo, por meio de abordagem analítica ou por abordagem com correlações empíricas, considerando ou não o escorregamento entre fases, em regime permanente ou transiente (Gould and Tek, 1970).

Escoamentos multifásicos podem ser classificados de acordo com a distribuição geométrica das fases no duto, o que dá origem aos regimes ou padrões de escoamento. Os regimes de escoamento normalmente são determinados visualmente, porém, quando a visualização não é possível, o regime pode ser determinado através da análise das pressões e do volume de vazios. O volume de vazios influencia no perfil de pressões ao longo da coluna e pode ser obtido a partir da fração local de líquido, parâmetro conhecido como holdup de líquido $\left(\mathrm{H}_{\mathrm{L}}\right)$.

Segundo Danielson et al. (2000), há três tipos de modelagem de escoamento multifásico, a saber, correlacional estacionária, mecanicista estacionária e mecanicista transiente. A primeira é baseada em equações exclusivamente empíricas e possui a vantagem de ser baseada em parâmetros que são fáceis de determinar, como por exemplo, as velocidades superficiais do líquido e do gás. A segunda e a terceira têm como base equações aproximadas deduzidas a partir da física do fenômeno, ajustadas empiricamente ao problema. Estas últimas são 
consideradas mais confiáveis, caso seja necessário fazer uma extrapolação para condições fora da faixa para a qual foram desenvolvidas, uma vez que derivam mais diretamente dos princípios das equações de balanço de massa, quantidade de movimento e energia.

Para descrever a transferência de massa entre as fases liquida e gasosa, há dois modelos clássicos: o modelo black oil, também conhecido como modelo de composição constante, e o modelo composicional. Nesse estudo foi adotado o modelo black oil, que é um modelo prático e simples que permite a caracterização macroscópica do escoamento de maneira satisfatoriamente precisa.

A simulação do escoamento, permite a determinação de características e parâmetros do escoamento, o dimensionamento de equipamentos e tubulações, a otimização da produção e o estudo do perfil de pressões ao longo da tubulação.

A simulação numérica pode ser implementada considerando-se regime permanente ou transiente. Embora mais simples (menos robusta), a simulação em regime permanente pode ser adequada (ou uma boa aproximação) em diversas aplicações (Danielson et. al, 2000) e tem a vantagem de consumir menor tempo computacional. Por outro lado, algumas operações como, por exemplo, a inicialização de escoamento no poço requer a utilização do modelo transiente.

Nesta dissertação, será apresentado o desenvolvimento de um simulador de escoamento em poços verticais que contenham água, óleo e gás. O sistema estudado está representado na Figura 1. O presente capítulo descreve a motivação, o objetivo do trabalho, situa o leitor no contexto geral do problema e cita alguns trabalhos realizados na área. No capítulo 2, são apresentados conceitos fundamentais à compreensão do problema. No capítulo 3, são apresentados o método matemático e o modelo computacional empregados, além da validação do simulador contra as curvas de Gilbert. No capítulo 4, são mostradas as aplicações do simulador e os resultados dos estudos paramétricos. Por fim, nos capítulos 5 e 6, respectivamente, encontram-se a conclusão e as referências bibliográficas, 


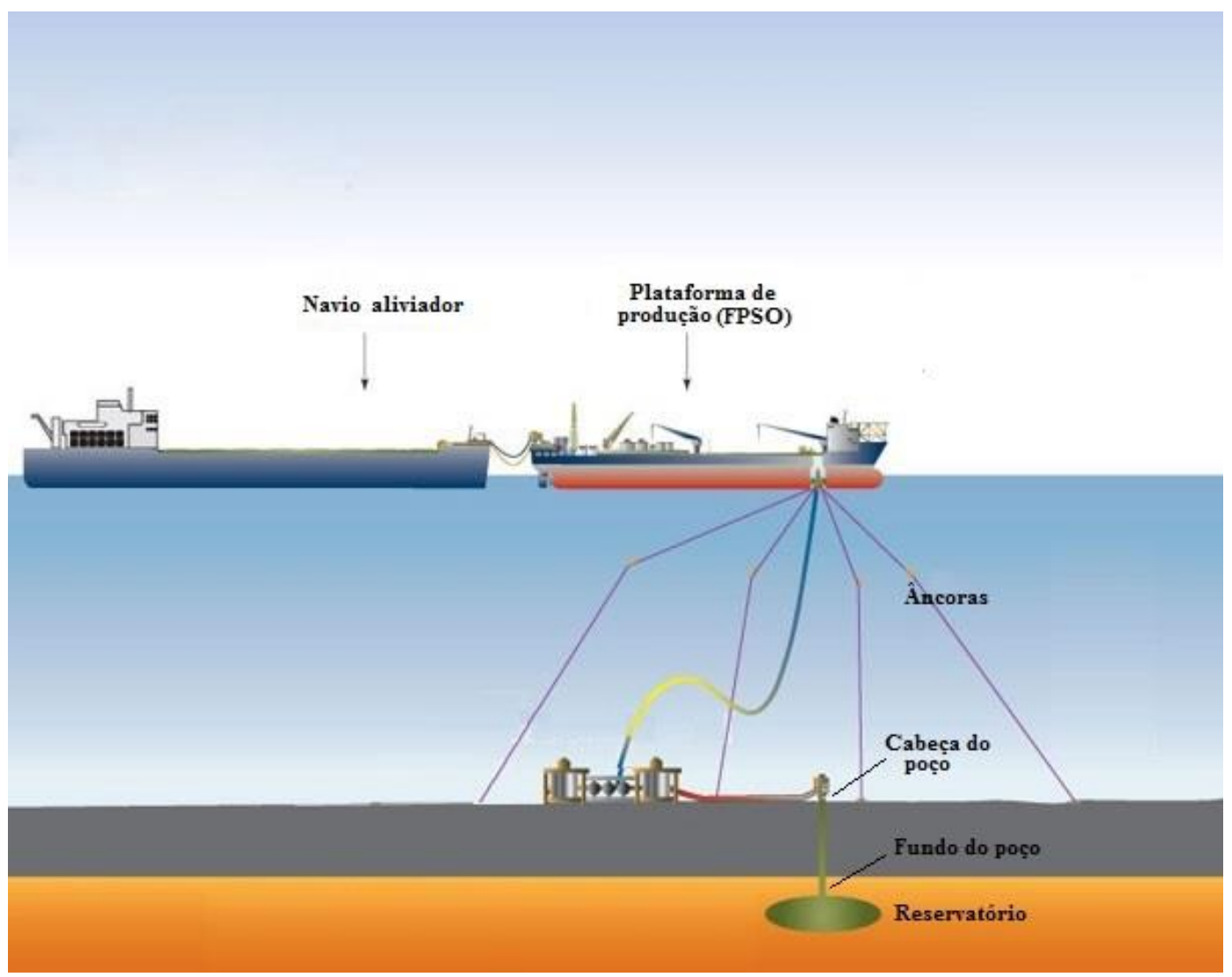

Figura 1 - Esquema de produção.

\section{4. \\ Revisão bibliográfica}

Gilbert (1954) publicou vários conjuntos de curvas de gradiente de pressão, sendo cada conjunto de curvas para condições específicas de vazão de óleo e diâmetro da coluna de produção. Essas curvas foram construídas a partir de dados experimentais de poços da Califórnia, com massas específicas entre 825 e 964 $\mathrm{kg} / \mathrm{m}^{3}$. Gilbert (1954) concluiu que os fatores que mais influenciam no perfil de queda de pressão em determinada região são: o diâmetro do escoamento, a vazão, a razão gás-líquido e a própria pressão na região. Essas curvas ficaram conhecidas como "curvas de Gilbert" e são largamente utilizadas e referenciadas em muitas aplicações e estudos. Estas curvas são usadas para validar o presente modelo.

Haggedorn \& Brown (1965) desenvolveram um método para determinação do Holdup de líquido $\left(\mathrm{H}_{\mathrm{L}}\right)$ baseado em correlações empíricas. Em 1977, esse método foi aprimorado dando origem ao método de Haggedorn \& Brown modificado (Economides et. al, 1994), que é amplamente utilizado em escoamentos líquido-gás. 
Atualmente simuladores comerciais são largamente utilizados para estudar o comportamento de escoamentos e para obter curvas de gradiente de pressão como as de Gilbert (1954). Entre alguns simuladores comerciais, destacam-se: OLGA, PIPESIM e MARLIM.

O modelo dinâmico bifásico do OLGA começou a ser desenvolvido através de um projeto para a empresa norueguesa STATOIL com o objetivo de simular escoamentos lentos transientes com transferência de massa. Em 1983, a primeira versão do olga já funcionava mas posteriormente sofreu um relevante aprimoramento em um programa de pesquisa envolvendo o Institute for energy technology (IFE) e SINTEF, com o apoio das empresas Conoco Norway, Esso Norge. Mobil Exploration Norway, Norsk Hidro AlS, Petro Canada, Saga Petroleum, Statoil e Texaco Exploration Norway. A base de dados de correlações empíricas foi ampliada e novas aplicações foram introduzidas no programa, que sofreu aprimoramentos até chegar ao modelo estendido de dois fluidos. (Bendiksen et. al, 1991). Atualmente o OLGA é referência na simulação em regime transiente.

O PIPESIM é um simulador de escoamento multifásico em regime permanente desenvolvido e comercializado pela empresa Schlumberger. Existe há aproximadamente 30 anos e possui um conjunto completo de correlações empíricas e modelos mecanicistas padrões na indústria do petróleo. $\mathrm{O}$ comportamento termodinâmico dos fluidos é avaliado pelo modelo black oil ou pelo modelo composicional. (Pipesim, 2009)

O MARLIM (Multiphase Flow and Artificial Lift Modelling) é um software desenvolvido pela Petrobras, de uso restrito aos funcionários e interesses da empresa. Foi desenvolvido considerando regime permanente e é baseado em algoritmos matemáticos e dados que foram desenvolvidos e colhidos durante muitos anos pela empresa. A interface do MARLIM foi construída utilizando a tecnologia Java (Petrobras, 2009).

A atenção e recursos que têm sido investidos na área de simulação por universidades mundialmente reconhecidas por sua excelência no ensino como, por exemplo, Stanford (2014) e Columbia (2014), que possuem projetos e laboratórios de pesquisa nessa área, evidenciam a relevância do assunto.

Dentre trabalhos relacionados recentemente publicados podemos citar o de Sousa (2010), que propõe modelos dinâmicos de escoamento monofásico e 
bifásico aplicados à rede de dutos para produção de óleo e gás e o de Nascimento (2013), que desenvolveu um simulador de escoamento multifásico utilizando o modelo mecanicista para determinar o gradiente de pressão. 


\section{2 \\ Conceitos fundamentais}

\section{1.}

\section{Padrões de escoamento}

Segundo Economides (1994), o comportamento do escoamento depende fortemente da maneira como as fases estão distribuídas na tubulação e isso tem um efeito na distribuição das pressões ao longo da coluna.

Para os sistemas mais simples, como por exemplo, escoamento vertical ou horizontal, estudos foram feitos a fim de relacionar o padrão de escoamento com os fluxos volumétricos das fases e com propriedades como densidade, viscosidade e tensão superficial. Esses estudos resultaram nos mapas de regime de escoamento, mostrado na Figura 2

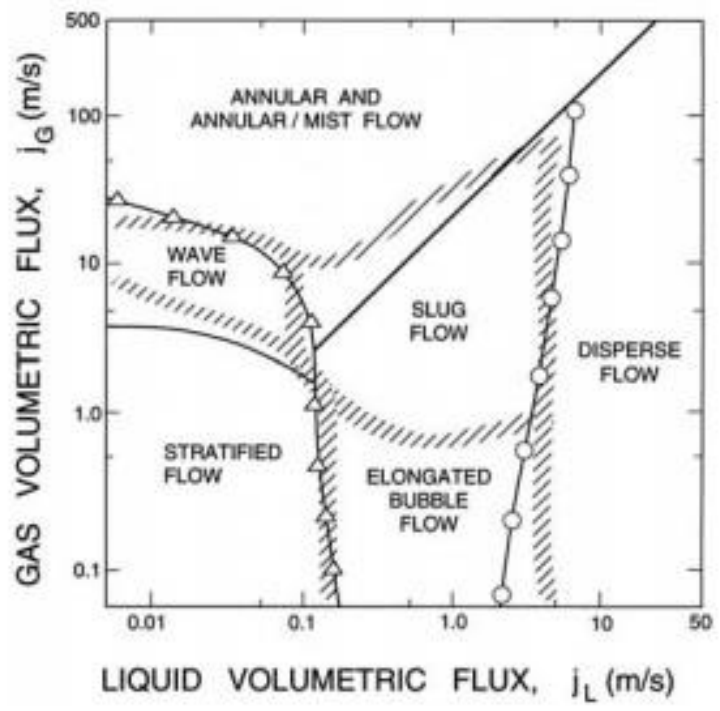

Figura 2 - Exemplo de mapa de regime de escoamento de uma mistura água/ar num duto horizontal de $2,5 \mathrm{~cm}$ de diâmetro a $25^{\circ} \mathrm{C}$ e 1 bar. Linhas sólidas e pontos representam observações experimentais, enquanto a linha de barras são as estimativas teóricas das faixas de transição (Brennen, 2005).

Um dos problemas desse mapa é que as linhas de interseção entre os regimes não são bem definidas devido às instabilidades. As transições entre as 
fases também podem ocorrer devido a outros detalhes não considerados, como a rugosidade das paredes. Além disso, esses mapas são aplicados apenas aos tamanhos de tubulações e fluidos utilizados no experimento que gerou o mapa (Brennen, 2005).

Segundo Brill e Mukherjee (1999) os principais regimes de escoamento são: bubbly flow (escoamento em bolhas), slug flow (escoamento em golfadas), churn flow (escoamento caótico) e annular flow (escoamento anular). Esses regimes de escoamento costumam ocorrer em sequência, podendo haver combinações entre eles ou estados intermediários (Figura 3).

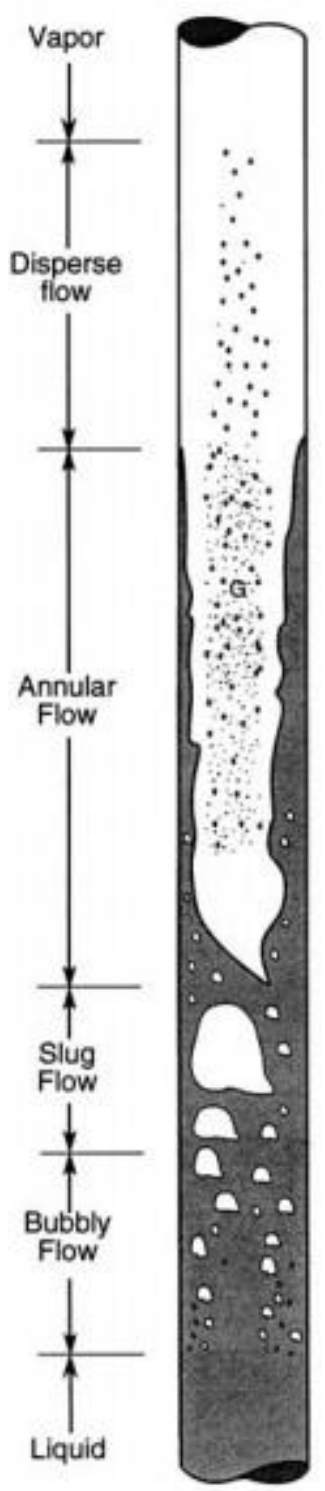

Figura 3 - Evolução do escoamento de uma corrente de líquido em uma tubulação (Brennen, 2005). 
O escoamento em bolhas se forma quando a pressão atinge um valor levemente abaixo da pressão de bolha e é caracterizado por pequenas bolhas de gás dispersas na fase líquida contínua.

O escoamento em golfadas consiste de tampões, também conhecidos como slugs de gás de formato bem definido que ocupam quase toda a área transversal do tubo. Eles ocorrem intermitentemente e separados por uma fase líquida, com ou sem bolhas dispersas.

O escoamento caótico consiste de fase líquida e gasosa ocorrendo sem que se possa distinguir a fase contínua e onde o formato dos tampões é indefinido.

O escoamento anular consiste de uma fase gasosa central fluindo axialmente enquanto uma fina camada de líquido flui pelas paredes do duto. Pequenas gotas de líquido também podem ser observadas no interior da fase gasosa.

\section{2. O Enfoque correlacional}

$\mathrm{Na}$ disponibilidade de amostras do reservatório para análise experimental, as propriedades do fluido podem ser medidas diretamente através da análise PVT, que é o estudo que envolve pressão, volume e temperatura. Porém, como esse estudo normalmente é conduzido na temperatura do reservatório, a variação das propriedades com a temperatura não é obtida por esse método para fins de cálculos utilizados na análise de sistemas de produção de petróleo. Além disso, em muitos casos a análise PVT pode não ser possível devido ao alto custo.

Além da medição direta, as propriedades de um fluido podem ser determinadas através de correlações empíricas, como as correlações compreendidas no modelo black oil, que considera que a composição do gás produzido é sempre constante, ou utilizando o modelo composicional, que considera que há transferência de espécies entre as fases, de forma que a composição do gás produzido varia com a posição e o somatório das propriedades de cada elemento ponderada com a fração molar origina as propriedades da mistura.

O modelo composicional é mais rigoroso na definição das propriedades de cada componente da mistura, mas isso não significa que fornecerá sempre 
melhores resultados, depende do sistema a ser estudado. Para sistemas de óleos normais a pesados, por exemplo, o modelo black oil proporciona resultados com um nível de precisão bem razoável, além de ser um modelo de solução muito mais rápida. Já para reservatórios de óleos leves e gás o modelo composicional é mais adequado.

A determinação das características do escoamento multifásico é essencial para o projeto e operação dos sistemas de produção. $\mathrm{O}$ escoamento multifásico pode ser modelado através do enfoque correlacional, baseado em dados experimentais ou através do enfoque mecanicista que é um modelo matemático cunhado em bases fenomenológicas e princípios físicos. O enfoque correlacional é fortemente empírico e por isso deve ter aplicação restrita aos limites inerentes aos experimentos que a geraram. Para uma aplicação mais generalizada, a modelagem mecanicista é mais aconselhável por ser mais confiável em uma faixa maior de condições (Oliveira, 2003).

Existem muitas correlações para o cálculo das características do fluxo multifásico. As correlações são classificadas em tipo 1, 2 e 3 , descritas a seguir.

A abordagem através das correlações do tipo 1 não utiliza mapas de padrão de escoamento, não considera a existência de escorregamento entre as fases. A única correlação requerida é para fator de fricção das duas fases. Exemplos: Poetmann \& Carpenter e Fancher \& Brown

As correlações do tipo 2, como por exemplo Hagedorn \& Brown, não utilizam mapas de padrões de escoamento, porém consideram o escorregamento entre as fases . Métodos nessa categoria apresentam correlação para o cálculo do holdup e correlação para o fator de fricção das fases.

As correlações que se enquadram no tipo 3, caracterizam-se por utilizarem mapas de padrão de escoamento e consideram o escorregamento entre as fases. Para cada padrão de escoamento é apresentada uma correlação para o cálculo do holdup e outra para o fator de fricção. Exemplos: Beggs \& Brill e Duns \& Ros

A modelagem pode, ainda, considerar regime permanente ou transiente. Os modelos transientes envolvem a solução analítica dos balanços de massa (Equação (1)), momento (Equação (2)) e energia (Equação (3)), e todos são, em essência, semi empíricos pois alguns termos, como $\Psi, \sum \mathrm{F}$ e $\mathrm{Q}$ são calculados via correlações empíricas. 


$$
\begin{aligned}
& \frac{d\left(V H_{i} \rho_{i}\right)}{d t}=\left(A H_{i} \rho_{i} U_{i}\right)_{\text {in }}-\left(A H_{i} \rho_{i} U_{i}\right)_{o u t}+\Psi \\
& \frac{d\left(V H_{i} \rho_{i} U_{i}\right)}{d t}=\left(A H_{i} \rho_{i} U_{i}^{2}\right)_{i n}-\left(A H_{i} \rho_{i} U_{i}^{2}\right)_{o u t}+\sum F \\
& \frac{d\left[V \rho_{G}\left(e_{G}+U_{G}{ }^{2} / 2+g y\right)+V \rho_{L}\left(e_{L}+{ }^{U_{L}}{ }^{2} / 2+g y\right)\right]}{d t}=\left(A \rho _ { G } U _ { G } \left(h_{G}+U_{G}{ }^{2} / 2+\right.\right. \\
& g y)_{\text {in }}+A \rho_{G} U_{L}\left(h_{L}+U_{G}{ }^{2} / 2+g y\right)_{\text {in }}-A \rho_{G} U_{G}\left(h_{G}+U_{G}{ }^{2} / 2+g y\right)_{\text {out }}- \\
& \left.A \rho_{G} U_{L}\left(h_{L}+U_{L}^{2} / 2+g y\right)_{\text {out }}\right)-Q
\end{aligned}
$$

onde $V$ é o volume de controle, $\rho$ é a massa específica, o subscrito " $i$ ” representa a fase (líquido ou gás), $\Psi$ representa a transferência de massa devido à condensação ou evaporação, $\sum F$ o somatório de forças (de pressão, gravitacional e ficcional) agindo sobre o fluido e $Q$ a taxa de transferência de calor através das paredes do duto.

Modelos em regime permanente ou estacionários consideram que as condições do escoamento em cada ponto do espaço, são constantes no tempo. Algumas situações transientes podem ser adequadamente modeladas como estacionárias, descritas por uma solução que leva em consideração as condições médias no tempo. Nesse caso, as derivadas no tempo são nulas e as Equações (1), (2) e (3) se tornam as Equações (4), (5) e (6).

$$
\begin{gathered}
\left(A H_{i} \rho_{i} U_{i}\right)_{\text {in }}=\left(A H_{i} \rho_{i} U_{i}\right)_{\text {out }}+\Psi \\
\left(A H_{i} \rho_{i} U_{i}{ }^{2}\right)_{\text {in }}=\left(A H_{i} \rho_{i} U_{i}{ }^{2}\right)_{\text {out }}+\sum F \\
A \rho_{G} U_{G}\left(h_{G}+U_{G}{ }^{2} / 2+g y\right)_{\text {in }}+A \rho_{G} U_{L}\left(h_{L}+U_{G}{ }^{2} / 2+g y\right)_{\text {in }}= \\
A \rho_{G} U_{G}\left(h_{G}+U_{G}{ }^{2} / 2+g y\right)_{\text {out }}+A \rho_{G} U_{L}\left(h_{L}+U_{L}{ }^{2} / 2+g y\right)_{\text {out }}+Q
\end{gathered}
$$


Os modelos mecanicistas estacionários partem das Equações (4), (5) e (6) usando corelações empíricas para $\Psi, \sum \mathrm{F}$ e Q.

Os modelos estacionários correlacionais não resolvem as Equações (4), (5) e (6) diretamente, mas sim com uma abordagem estritamente empírica. Baseando-se em dados experimentais, através de curvas que se reproduzem esses dados, obtémse parâmetros (normalmente adimensionais) do modelo para solucionar as equações. As correlações são baseadas em velocidades superficiais das fases, propriedades dos fluidos e diâmetro da tubulação. É possível caracterizar uma larga gama de escoamentos através desses modelos correlacionais de maneira altamente satisfatória para projetos de sistemas que envolvem escoamentos multifásicos (Danielson et. al, 2000).

\section{3.}

\section{Curvas de IPR e TPR}

A relação entre a pressão no fundo do poço $\left(\mathrm{p}_{\mathrm{wf}}\right)$ e a vazão de produção $(\mathrm{Q})$, pode ser expressa em uma curva conhecida como curva de IPR (inflow performance relationship). A IPR é usada para avaliar a produtividade do reservatório e consiste na representação gráfica da relação entre a pressão de fundo em fluxo $\left(\mathrm{p}_{\mathrm{wf}}\right)$ com a vazão de produção de líquido. A curva de IPR é útil na estimativa da capacidade de produção do poço, no projeto da coluna de produção e para o planejamento do método de recuperação artificial. A inclinação da curva é dada pelo índice de produtividade do poço, J, que é uma propriedade característica de cada poço e é dado por:

$$
J=\frac{Q}{\left(p_{e}-p_{w f}\right)}
$$

Porém a vazão de produção só existe enquanto existir um equilíbrio apropriado entre duas condições de pressão no fundo do poço. Primeiramente, essa pressão deve ser suficientemente alta para promover elevação. Em segundo lugar, deve ser suficientemente baixa para criar um diferencial de pressão que promova o escoamento do fluido do reservatório para dentro do poço. Ou seja, A IPR avalia a segunda condição. A primeira é avaliada por uma curva que 
relaciona a pressão $p_{w f}$ com a pressão $p_{t}$ na cabeça do poço. Para dada pressão na cabeça do poço, a vazão de produção varia com a pressão de fundo em fluxo $\left(p_{w f}\right)$. Plotando esses dois parâmetros em um sistema de coordenadas cartesianas, temos a curva conhecida como curva de TPR (Tubing Performance Relationship). Plotando ambas IPR e TPR no mesmo gráfico, a capacidade de produção do poço pode ser estimada como sendo a interseção dessas duas curvas (Lyons e Pilsgra, 2005).

\section{4.}

\section{Curvas de gradientes de pressão}

Ao escoar em direção à superfície, o óleo é submetido a uma diminuição gradual na pressão e temperatura, o que causa o desprendimento de eventuais hidrocarbonetos leves que estejam dissolvidos no óleo nas condições de subsuperfície. Essa variação de pressão pode ser traduzida em um gráfico de gradiente de pressão, que permite visualizar a pressão em diferentes pontos da coluna e que é essencial no estudo da produção em poços de petróleo.

Curvas de gradientes de pressão reproduzem a queda de pressão com a diminuição da profundidade sofrida pelo fluido em escoamento para condições operacionais específicas e são utilizadas, por exemplo, para construir a TPR de um determinado poço. Os conjuntos de curvas de gradiente de pressão desenvolvidas por Gilbert (1954), que podem ser vistas no Anexo B, são largamente utilizadas para resolver problemas de performance de poços. Cada curva corresponde a uma razão gás-líquido (RGL). Essas curvas estão disponíveis para vazões de 50 a 600 bbl/d e diâmetros de 1,66 a 3,5 polegadas e não levam em consideração especificidades do poço tais como salinidade, teor de asfaltenos ou emulsificação severa, fatores que podem causar uma queda de pressão mais acentuada. À baixas velocidades, o escorregamento da fase gasosa contribui fortemente para a perda de carga enquanto que a altas velocidades a fricção com as paredes da tubulação é o fator que mais influencia. Em alguma faixa intermediária, encontram-se os valores de velocidades que produzem os gradientes ótimos de pressão (Lyons e Pilsgra, 2005).

Uma das utilidades de uma curva de gradiente de pressão é determinar a pressão no fundo do poço $\left(p_{w f}\right)$ a partir da pressão na cabeça do poço $\left(p_{t}\right)$, dado o 
comprimento da coluna de produção que conecta essas duas extremidades. O procedimento é o seguinte: partindo-se da $p_{t}$, projetando-se na curva de RGL correta, encontra-se o comprimento equivalente a esta pressão. Em seguida somase ao comprimento encontrado a profundidade do poço e, voltando na curva de RGL, determina-se $p_{w f}$ no eixo das pressões. Esse procedimento está ilustrado na Figura 4.

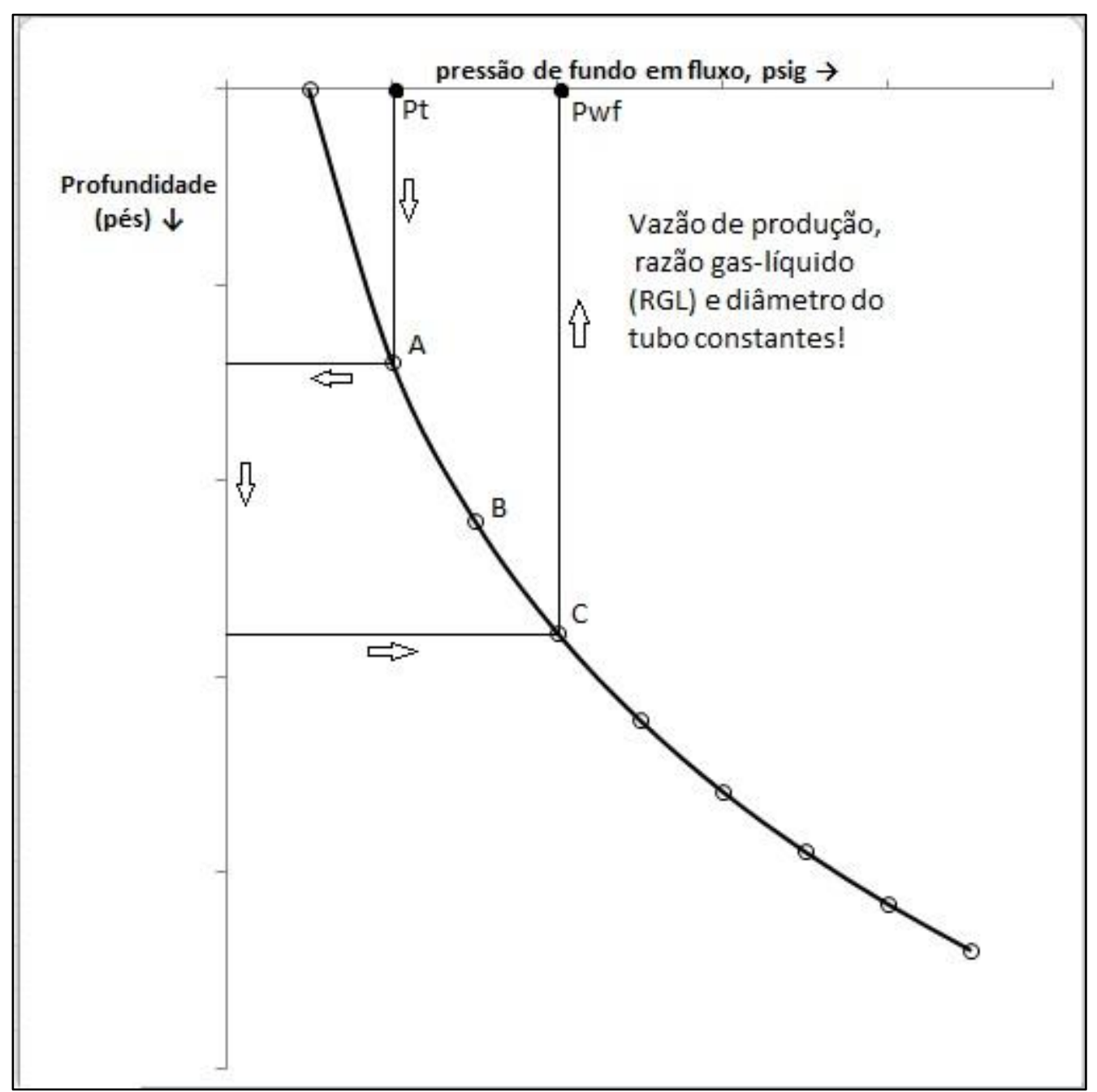

Figura 4 - Determinação da $\mathrm{p}_{\mathrm{wf}}$ a partir de uma curva de distribuição de pressão para um escoamento bifásico.

A curva apresentada na Figura 4 é construída para parâmetros tais como vazão de produção, diâmetro de tubo e razão gás-líquido específicos e apresenta um perfil bem definido e com concavidade para cima. Porém Baxendel e Thomas (1961) mostraram, em seu trabalho, que esse padrão de curva é duvidoso para 
baixas pressões. De fato, os dados obtidos experimentalmente (Figura 5) mostram a ocorrência de curvatura reversa na região de baixas pressões.

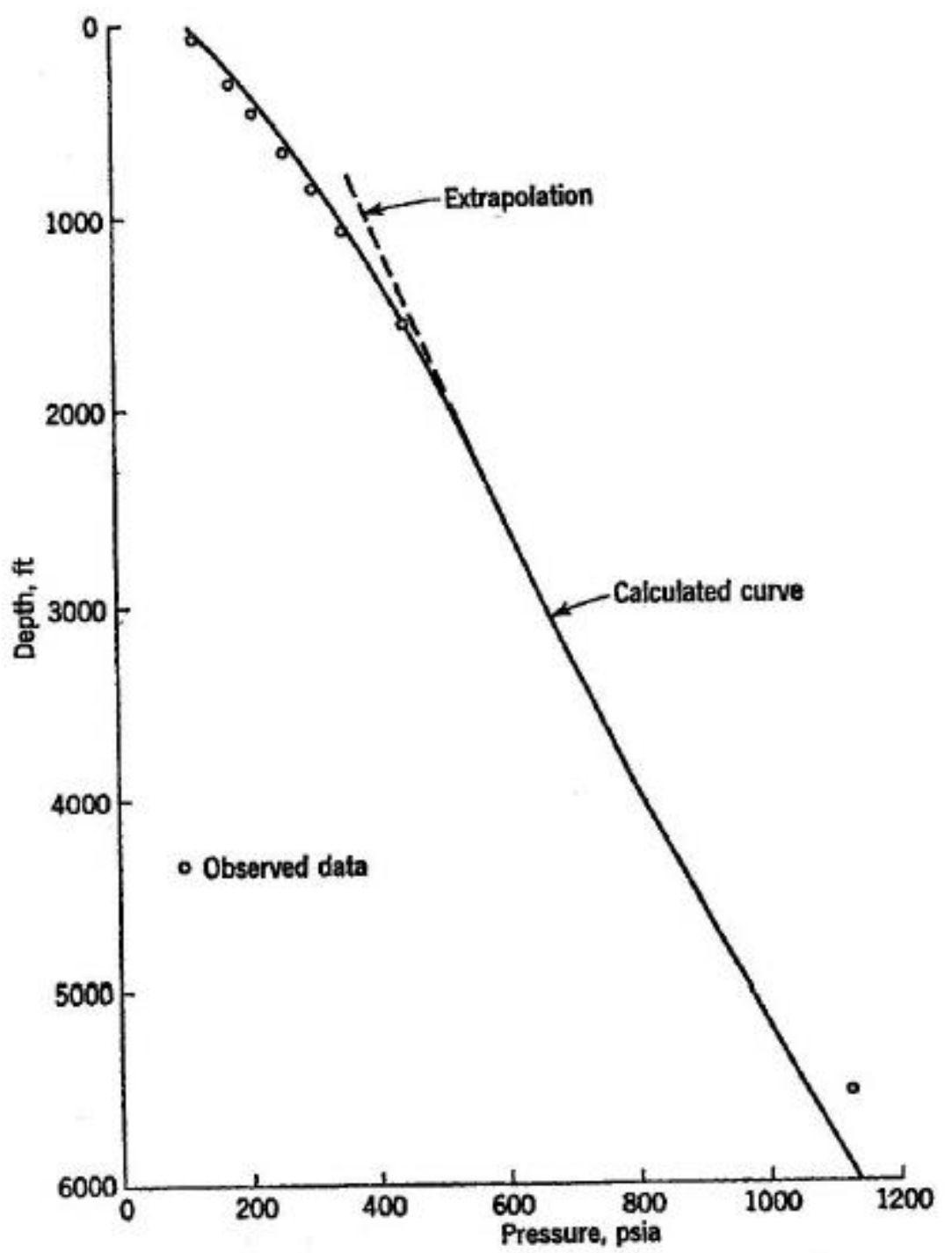

Figura 5-Validação experimental da curvatura reversa em curvas de distribuição de pressão, à baixas pressões (Baxendell e Thomas, 1961).

Para a construção da curva de gradiente de pressão, é imprescindível o conhecimento da fração do tubo ocupada por líquido, ou seja, o holdup de líquido $\left(H_{L}\right)$, que exprime a relação da área da seção transversal ocupada por líquido $\mathrm{n}$ tubulação e a área transversal total da tubulação onde ocorre o escoamento, conforme Equação (8). A partir do conhecimento da fração ocupada pelo líquido e pelo gás, é possível calcular as propriedades da mistura, o que possibilita o cálculo da perda de carga.

$$
\mathrm{H}_{\mathrm{L}}=\frac{\text { Area transversal ocupada pelo líquido }}{\text { Area transversal total }}
$$


O holdup do líquido, $H_{L}$, pode ser calculado através de correlações e seu valor pode variar de zero (quando há somente gás) a 1 (quando há somente líquido na tubulação). O holdup de gás $\left(H_{g}\right)$ é definido como $1-\mathrm{H}_{\mathrm{L}}$.

O holdup do líquido, $H_{L}$, pode ser calculado de forma simplificada, baseando-se na premissa de que gás e líquido viajam à mesma velocidade, através das vazões in sito de líquido $\left(Q_{l}\right)$ e gás $\left(Q_{g}\right)$. Nesse caso tem-se o holdup de líquido sem escorregamento $\left(\lambda_{L}\right)$ :

$$
\lambda_{L}=\frac{Q_{l}}{Q_{l}+Q_{g}}
$$

Analogamente, o holdup do gás sem escorregamento $\left(\lambda_{\mathrm{g}}\right)$ pode ser definido como: $\lambda_{\mathrm{g}}=1-\lambda_{\mathrm{L}}$.

\section{5.}

\section{Gás lift}

A produção de petróleo requer que o óleo, que se encontra em uma condição de equilíbrio e submetido à pressão estática do reservatório, escoe verticalmente através da coluna de produção por diferença de pressão. Caso a pressão do reservatório seja suficiente para fazer com que o óleo chegue à superfície, o poço é chamado de surgente. Caso a pressão do reservatório não seja suficiente para vencer a pressão hidrostática e a perda de carga na tubulação até chegar à superfície, o poço é não surgente.

Segundo Roman e Hernández (2005), métodos de elevação artificial são necessários em poços cuja pressão do reservatório não é suficiente para produzir a vazão de óleo desejada com retorno econômico satisfatório.

O gás lift é um dos métodos de elevação artificial mais utilizados na produção de petróleo devido ao baixo custo desse método aliado à simplicidade operacional e a eficácia em uma larga faixa de condições operacionais. A injeção de gás pode ocorrer de forma contínua ou intermitente, sendo a contínua a mais utilizada (Roman e Hernández , 2005). 
O princípio básico do método consiste na diminuição da massa específica na fase líquida através da injeção de gás. A gaseificação da fase líquida a torna menos densa e a mesma flui com maior facilidade. Além disso, a expansão do gás ao entrar na coluna propulsiona a mistura no sentido da superfície (Guo et al., 2007). A Figura 6 apresenta um diagrama esquemático simplificado de um sistema de gás lift mostrando o poço, a válvula de injeção de gás (válvula de gás lift), e os equipamentos de superfície.

Segundo Roman e Hernández (2005), o gás mais utilizado pelo método é o próprio gás natural. Porém outros gases podem ser utilizados e podem ser até mais vantajosos economicamente, como por exemplo, o nitrogênio.

Um importante parâmetro a ser determinado no método, é a altura de alocação da válvula injetora de gás, a fim de obter a máxima vazão de produção possível. (Roman e Hernández, 2005).

A injeção de gás pode ser contínua ou intermitente. Uma operação de gás lift contínuo pode ser definida como sendo o fluxo estacionário do fluido aerado do fundo do poço em direção à superfície. A operação intermitente é caracterizada por injeções intermitentes de gás do fundo do poço em direção à superfície. Nesse caso o fluxo é considerado transiente.

O gás lift contínuo é adequado para poços com alto índice de produtividade e pressão do reservatório razoavelmente alta com relação à profundidade. O uso do gás lift intermitente é mais apropriado para poços com alto índice de produtividade e baixa pressão do reservatório ou baixo índice de produtividade e baixa pressão do reservatório. O tipo de injeção também depende do volume de fluidos a serem produzidos, da quantidade de gás disponível para injeção e das condições específicas do reservatório como é o exemplo de sistemas com alta diferencial de pressão, $p_{e^{-}} p_{w f}$, em que o fluxo intermitente causaria excessiva produção de areia e, portanto, não seria adequado (Guo, 2007).

O posicionamento da válvula de gás lift e a quantidade delas depende de uma otimização de hidráulica de poço, mas como regra geral, é desejável que a válvula seja alocada na maior profundidade possível. 


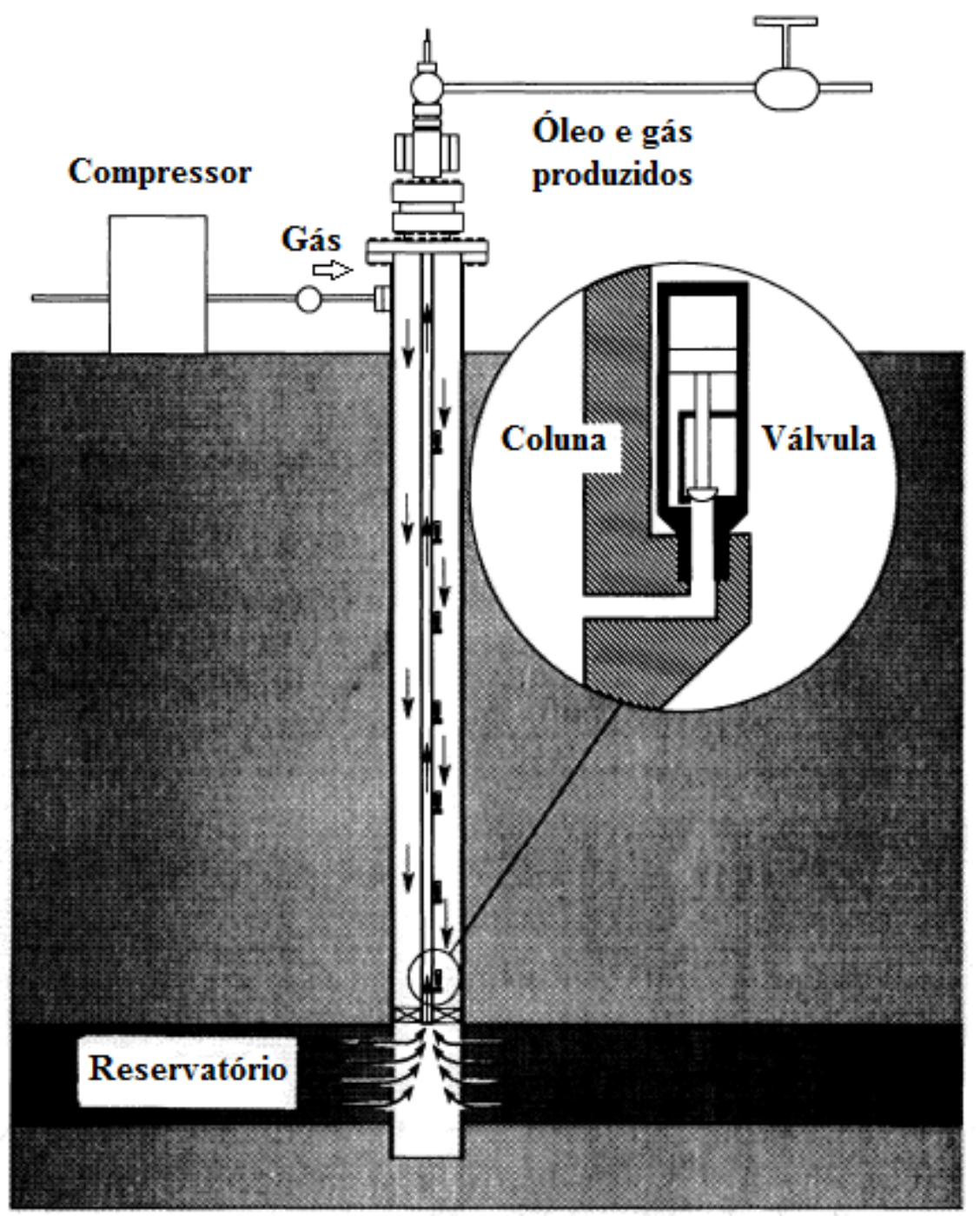

Figura 6- Ilustração simplificada de um Sistema de gás lift.

\section{6.}

\section{Modelo Black Oil}

Em simulação chama-se modelagem black oil aquela em que pode ser assumida uma composição constante para o óleo durante sua vida produtora. A abordagem black oil é largamente utilizada na prática e muitos estudos de simulação de reservatórios de escoamento adotam esta modelagem. Nessa modelagem de determinação das propriedades da mistura os componentes são traduzidos por propriedades intrínsecas, dependentes do estado termodinâmico em combinação com formulações adicionais que traduzem o grau da mistura existente entre tais componentes e suas consequências na determinação nas propriedades da mistura (Oliveira, 2003). 
Segundo Vilella (2004), as correlações black oil foram desenvolvidas especificamente para sistemas de óleo cru / gás / água e são assim muito úteis para prever o comportamento das fases no fluxo de um poço de petróleo. Quando usadas em conjunto com as opções de calibração, as correlações black oil podem produzir dados de comportamento de fases precisos, a partir de um mínimo de dados de entrada.

O modelo black oil, foi desenvolvido para óleos com grau API menor que 40, que possuem gás associado e que sofram mudanças na composição das fases tão pequenas que podem ser desprezadas. Dessa forma o modelo assume que a composição do gás produzido é sempre constante em qualquer ponto da coluna de produção. O modelo define alguns parâmetros, tais como $R_{s}$, que é um parâmetro que leva em consideração o gás que solubiliza ou evapora da fase oleosa, $B_{o}$, que se refere á variação de volume do óleo devido à presença de gás dissolvido, que aumenta o volume do óleo e $B_{g}$, que refere-se à variação de volume da fase gasosa. Ambos $B_{o}$ e $B_{g}$ são função da pressão e temperatura. Os valores numéricos desses parâmetros podem ser obtidos experimentalmente, utilizando amostra do teste de formação do reservatório, ou determinados através de correlações empíricas (Brill and Mukherjee, 1999).

A abordagem black oil é largamente utilizada na prática e a grande maioria dos estudos de reservatório adota esta modelagem. Assume-se para o óleo uma massa específica $(\rho)$ constante. $O$ fluido resultante vai se tornando mais pesado na medida em que o gás vai saindo de solução.

As correlações black oil foram desenvolvidas especificamente para sistemas de óleo cru / gás / água e são assim muito úteis para prever o comportamento das fases no fluxo de um poço de petróleo. Quando usadas em conjunto com as opções de calibração, as correlações black oil podem produzir dados de comportamento de fases precisos, a partir de um mínimo de dados de entrada. Elas são particularmente convenientes em estudos de gás lift, onde os efeitos da variação do RGO e corte de água estão sob investigação. Porém, se é importante uma previsão precisa do comportamento das fases em sistemas com hidrocarbonetos leves, é recomendada a aplicação de modelos composicionais. 


\section{3 \\ Modelagem}

\section{1. Metodologia}

O programa simula o comportamento do escoamento multifásico vertical, unidimensional e em regime permanente através da discretização da coluna de produção de comprimento conhecido. $\mathrm{O}$ esquema de poço utilizado para desenvolver o simulador está ilustrado na Figura 7. Dessa forma, a coluna é dividida em células pequenas o suficiente para que se considere que as propriedades do fluido na célula sejam constantes. A discretização é feita na pressão, de forma que dado o passo de pressão, calcula-se o comprimento correspondente de cada célula. Isso é feito sucessivamente, até chegar na condição de contorno desejada. A discretização da coluna esta representada na Figura 8. A linguagem computacional utilizada para desenvolver o simulador foi Visual Basic.

O Visual Basic (VB) é uma linguagem de programação baseada na linguagem BASIC. Trata-se de uma linguagem de programação visual, que utiliza o paradigma de orientação a objetos e é voltada para eventos. O VBA (Visual Basic for applications) é um subconjunto do $\mathrm{VB}$, desenvolvido para atuar em conjunto com as aplicações do Microsoft Office (Dreux e Azevedo, 2009). 


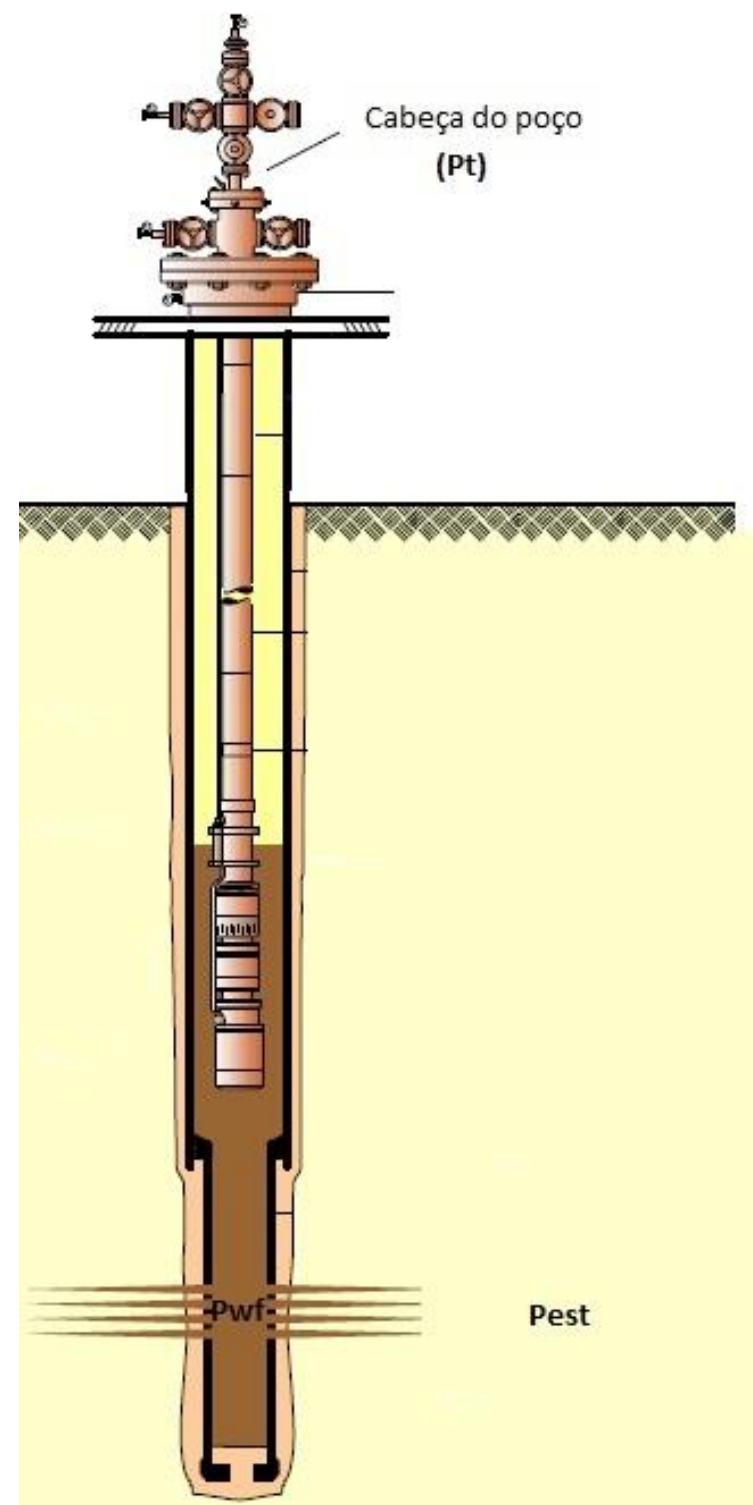

Figura 7 - Esquema de poço utilizado para desenvolver o simulador. $\mathrm{Pt}=$ pressão na cabeça do poço; $p_{w f}=$ pressão no fundo do poço; $p_{\text {est }}=$ pressão estática do reservatório. 


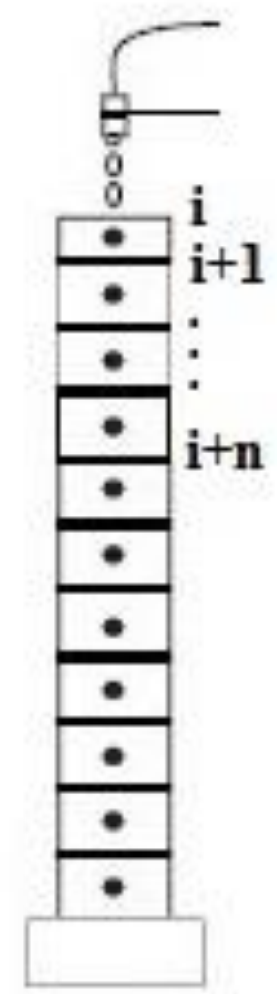

Figura 8- Representação da discretização da coluna de produção

Após especificar as condições do problema, fornecendo os dados de entrada, o programa é executado, e os resultados são obtidos na forma de tabelas e gráficos, possibilitando a análise do comportamento do escoamento e a análise de sensibilidade de vários parâmetros, bem como outros estudos.

O programa foi elaborado em duas versões e a escolha da versão mais adequada depende dos dados que se têm disponíveis e do que se deseja obter como resposta. Na primeira versão do programa, são dados o comprimento da coluna de produção e a pressão na cabeça do poço, obtendo-se como saída a pressão no fundo do poço. Na segunda versão do programa, são dados de entrada a pressão no fundo do poço e o comprimento da coluna de produção, obtendo-se a pressão na cabeça do poço como saída. Essa informação encontra-se resumida na Tabela 1

O programa é alimentado com os seguintes dados de entrada: 
- vazão (Q) em STBO/dia

- diâmetro (d) do duto em polegadas

- rugosidade interna do duto (adimensional)

- densidade do gás (adimensional)

- grau API do óleo $\left(\gamma_{\mathrm{API}}\right)$

- Razão gás-Líquido (RGL) em scf/STB

- Temperatura nas condições iniciais do problema (Tres ou $\mathrm{T}_{\text {ini }}$ ) em ${ }^{\circ} \mathrm{F}$

- Passo para incremento da pressão (dp) em psi

Apesar de a RGL ser um dado de entrada necessário à execução dos cálculos pelo simulador, não é necessário fornecer um valor inicial, pois automaticamente são feitos todos os cálculos para RGL variando de 0 a 1400 scf/STBO, com um passo de $100 \mathrm{scf} / \mathrm{STBO}$.

Tabela 1 - Informações sobre variáveis que são dados de entrada e saída para cada versão do programa.

$\begin{array}{ccc}\text { Variável } & \text { Versão 1 } & \text { Versão 2 } \\ \mathrm{P}_{\mathrm{t}} & \text { Entrada } & \text { Saída } \\ \mathrm{P}_{\mathrm{wf}} & \text { Saída } & \text { Entrada } \\ \mathrm{H}_{\text {colu }} & \text { Entrada } & \text { Entrada }\end{array}$

Escopo de aplicação do programa:

-Regime permanente

-Escoamento unidimensional $(\mathrm{L}>>\mathrm{d})$

-Poço vertical

-RGO de 0 a 1400

$-{ }^{\circ} \mathrm{API}$ entre 15 e 40

-gás lift contínuo alocado no fundo do poço

As unidades utilizadas no cálculo das propriedades nesse trabalho não foram no sistema internacional de unidades SI por motivos práticos. $\mathrm{Na}$ indústria de petróleo se utiliza o sistema de unidades de campo, de forma que se a pesquisa fosse realizada toda no sistema internacional de unidades, para que fosse utilizada 
de forma prática, todas as unidades deveriam ser transferidas para as unidades aqui utilizadas. Além disso, a bibliografia relacionada contém gráficos e equações que já estão nas unidades de campo.

A temperatura do óleo em um reservatório de petróleo é influenciada pela sua proximidade com o manto terrestre visto que ocorre troca de calor através das rochas que compõem a formação. Essa temperatura permanece em equilíbrio até que um poço seja perfurado, provocando o deslocamento do óleo em direção à superfície.

Uma vez que a temperatura diminui com a diminuição da profundidade, o óleo vai perdendo calor conforme sobe em direção à superfície. Dessa forma, a temperatura do óleo na superfície é menor que sua temperatura inicial (no reservatório). Visto que o estudo da temperatura foge ao escopo deste trabalho, para levar em consideração essa variação de temperatura, foi adotado um modelo simplificado baseado na publicação de Cardozo e Hamza (2014), que conduziram um estudo onde coletaram dados experimentais a fim de traçar o perfil geotérmico da bacia de Campos. Os resultados indicaram um gradiente geotérmico de 24 a $41^{\circ} \mathrm{C} / \mathrm{Km}$.

\section{2. \\ Modelo matemático}

\subsection{1.}

\section{Considerações gerais}

Uma vez que os volumes do óleo e do gás variam com a pressão e a temperatura, ao expressar o volume de gás ou de óleo, é necessário definir as condições em que foi obtido esse volume. A condição de referência é a condição padrão ou condição de superfície (temperatura $=60^{\circ} \mathrm{F}$ e pressão $=14,7$ psia), que é a condição de pressão e temperatura teóricas, assumidas na superfície e no tanque de estocagem que fica na plataforma de produção, como ilustrada na Figura 1. O volume de gás medido ou calculado na condição padrão é expresso, no presente 
trabalho, em scf, do inglês standard cubic feet, que significa pés cúbicos medido na condição padrão.

A seguir serão descritas as equações matemáticas do modelo que foram utilizadas para o desenvolvimento do simulador. A demonstração do cálculo de cada propriedade será precedida de uma breve explicação do seu significado físico.

\subsection{2.}

\section{Cálculo das propriedades}

A rugosidade absoluta de uma tubulação, $e$ é a altura média das irregularidades presentes em suas paredes internas. Esse parâmetro influencia no escoamento, pois quanto maior a rugosidade maior a perda de carga devido à fricção. A rugosidade relativa, $K$, calculada pela Equação (11), é a razão entre a rugosidade absoluta e uma medida característica do duto; em dutos circulares, por exemplo, essa medida é o diâmetro d.

$$
K=\frac{e}{d}
$$

A densidade relativa do óleo, ou gravidade específica do óleo $\left(\gamma_{o}\right)$ expressa a massa específica do óleo com relação à massa específica da água, ambas medidas à mesma temperatura. Esse parâmetro pode ser calculado a partir da massa específica do óleo, como mostrado na Equação (13), ou então a partir do grau API $\left(\gamma_{A P I}\right)$, conforme apresentado pela Equação (12).

$$
\begin{gathered}
\gamma_{o}=\frac{\rho_{o}}{\rho_{w}} \\
\gamma_{o}=\frac{141,5}{131,5+\gamma_{A P I}}
\end{gathered}
$$

onde $\rho_{w}$ é a massa específica da água. 
A densidade relativa do gás $\left(\gamma_{g}\right)$ é a massa específica do gás associado com relação à massa específica do ar e pode ser obtido conforme a Equação (14).

$$
\gamma_{g}=\frac{\rho_{g}}{\rho_{a r}}=\frac{M_{g}}{M_{a r}}
$$

onde $\rho_{g}$ é a massa específica do gás, $\rho_{a r}$ é a massa específica do ar, $M_{g}$ é a massa molar do gás e $M_{a r}$ é a massa molar do ar.

A vazão de água na superfície $\left(Q_{w s t}\right)$ pode ser obtida a partir da fração de água, $f_{w}$, multiplicando-a pela vazão total de líquido na superfície $(\mathrm{Q})$ :

$$
Q_{w s t}=f_{w} Q
$$

A vazão de óleo na superfície $\left(Q_{o s t}\right)$ é a fração de óleo, obtida subtraindo a fração de água de 1, vezes a vazão total, como mostrado a seguir:

$$
Q_{o s t}=\left(1-f_{w}\right) Q
$$

A área transversal do escoamento $(A)$ é seção transversal da tubulação por onde passa o fluido e é definido por:

$$
A=\frac{\pi d^{2}}{4}
$$

onde $d$ é o diâmetro da coluna de produção.

A razão de solubilidade na pressão de bolha $\left(R_{s b}\right)$ é a solubilidade do óleo no ponto de bolha, ou seja, quando a primeira bolha de gás está prestes a emergir da solução líquida. Logo, terá o mesmo valor numérico da Razão gás óleo $(R G O)$ que expressa o volume total de gás dissolvido por volume de óleo, conforme apresentado na Equação (18).

$$
R G O=\frac{\text { Volume de gás livre total na condição padrão }}{\text { volume de óleo na condição padrão }}
$$


Mas a RGO não é dada e precisa ser calculada indiretamente a partir da razão gás líquido $(R G L)$, que é um dado de entrada e expressa o volume total de gás dissolvido por volume total de líquido (óleo + água), ambos medidos na condição padrão. $R G L$ pôde ser obtida dividindo a vazão de gás, $Q_{g}$, pela vazão total de líquido $Q$ (óleo + água).

$$
R G L=\frac{Q_{g}}{Q}
$$

Isolando $Q$ da Equação (16) e substituindo na Equação (19), obtemos a Equação (20):

$$
R G L=\frac{\frac{Q_{g}}{Q_{o s t}}}{\left(1-f_{w}\right)}=\frac{Q_{g}}{Q_{o s t}}\left(1-f_{w}\right)=R G O\left(1-f_{w}\right)
$$

Logo,

$$
R G O=\frac{R G L}{\left(1-f_{w}\right)}
$$

Mas, como já dito anteriormente $R_{s b}=R G O$. Logo,

$$
R_{s b}=\frac{R G L}{\left(1-f_{w}\right)}
$$

A quantidade de hidrocarbonetos leves na fase líquida na temperatura do reservatório é limitada pela pressão e pela quantidade de moléculas presentes. Um óleo é dito saturado quando encontra-se em uma condição em que, uma pequena diminuição na pressão, provocará a evolução da primeira bolha de gás. Um caso especial de saturação é a pressão de bolha $\left(p_{b}\right)$ que é a pressão na qual a primeira bolha de gás emerge da solução. $p_{b}$ foi obtida pela Correlação de Standing, conforme mostrado nas Equações (23) e (24):

$$
P_{b}(p s i)=18\left(\frac{R_{s b}}{\gamma_{g}}\right)^{0,83} 10^{y_{g}}
$$


onde $T$ é a temperatura e $y_{g}$ é dado por:

$$
y_{g}=0,00091 T\left(^{\circ} \mathrm{F}\right)-0,0125^{\circ} \mathrm{API}
$$

A razão de solubilidade do gás no óleo $\left(R_{s o}\right)$ é um parâmetro definido no modelo Black Oil que expressa a quantidade de gás dissolvida no óleo nas condições de subsuperfície expressa em condições padrão, ou seja, é a quantidade de gás que emerge da solução líquida no transporte entre reservatório e superfície devido à queda de pressão e temperatura conforme representado pela Equação (25). $R_{s o}$ é definida em termos da quantidade de gás e óleo que chegam na superfície durante a produção. Esse parâmetro pode ser obtido experimentalmente ou através de correlações empíricas como mostrado nas Equações (26) e (27).

$$
\begin{gathered}
R_{s o}=\frac{\text { Volume de gás nas condições padrão (que saiu de solução) }}{\text { Volume de óleo nas condições padrão }} \\
y_{g}=0,00091 T\left({ }^{\circ} F\right)-0,0125^{\circ} A P I \\
R_{S o}\left(\frac{s c f}{b b l}\right)=\gamma_{g}\left(\frac{p}{18\left(10^{\gamma g}\right)}\right)^{1 / 0,83}
\end{gathered}
$$

onde $p$ é a pressão in situ.

O volume do óleo que chega ao tanque de estocagem é menor que o volume do óleo no reservatório, que entra na coluna de produção. Essa mudança no volume se deve principalmente à saída do gás dissolvido no óleo e é expressa pelo fator volume de formação do óleo $\left(B_{o}\right)$ que é definido como o volume de óleo no em condições de subsuperfície necessário para produzir um barril de óleo nas condições de superfície, conforme Equação (28). O cálculo desse parâmetro do modelo Black Oil foi feito através da correlação de Standing, conforme apresentado da Equação (29) à Equação (34).

$$
B_{o}=\frac{\text { Volume do óleo no reservatório }}{\text { Volume de óleo nas condições padrão }}
$$


Para $\mathrm{P}<\mathrm{P}_{\mathrm{b}}$ :

$$
F=R_{s o}\left(\frac{s c f}{b b l}\right)\left(\frac{\gamma_{g}}{\gamma_{o}}\right)^{0,5}+1,25 T\left({ }^{\circ} F\right)
$$

onde $F$ é um parâmetro interno do sistema de correlações.

$$
B_{o}\left(\frac{b b l}{S T B O}\right)=0,972+0,000147 F^{1,175}
$$

Para $\mathrm{P}>\mathrm{P}_{\mathrm{b}}$ :

$$
\begin{gathered}
F=R_{S b}\left(\frac{s c f}{b b l}\right)\left(\frac{\gamma_{g}}{\gamma_{o}}\right)^{0,5}+1,25 T\left({ }^{\circ} F\right) \\
B=0,972+0,000147 F^{1,175}
\end{gathered}
$$

onde $B$ é um parâmetro interno do sistema de correlações.

$$
Z_{o}=\frac{5 R_{s b}\left(\frac{s c f}{b b l}\right)+17,2 T\left({ }^{\circ} \mathrm{F}\right)-1180 \gamma_{g}+12,61 \gamma_{A P I}-1433}{p(p s i) 10}
$$

onde $Z_{o}$ é a compressibilidade do óleo nas condições de subsaturamento (psi ${ }^{-1}$ ).

Por fim,

$$
B_{o}=B e^{\left(z_{o}\left(p_{b}-p\right)\right)}
$$

A viscosidade é uma propriedade relacionada à resistência de um fluido ao escoamento, quando submetido a uma tensão cisalhante. Essa propriedade é influenciada pela pressão e pela temperatura. $\mathrm{O}$ aumento da temperatura provoca diminuição da viscosidade e a diminuição da pressão provoca uma diminuição na viscosidade. No caso de óleos com gás dissolvido, quanto menor a quantidade de gás dissolvido, maior a viscosidade. Enquanto o óleo contém gás dissolvido, ele é chamado de óleo vivo. O óleo na superfície, ou seja, quando todo o gás já saiu de 
solução, é chamado de óleo morto. a Viscosidade do óleo foi calculada através da Correlação de Beggs e Robinson que possui um conjunto de correlações para o cálculo da viscosidade do óleo morto $\left(\mu_{d o}\right)$, Equações (35) e (36) e outro para o cálculo da viscosidade do óleo vivo $\left(\mu_{o}\right)$, Equação (37) à Equação (39)

$$
x=T^{-1,163} e^{\left(6,9824-0,04658 \gamma_{A P I}\right)}
$$

onde $x$ é um parâmetro interno da correlação.

$$
\begin{gathered}
\mu_{d o}=10^{x}-1 \\
A=10,715 \times\left(R_{s o}+100\right)^{-0,515} \\
B=5,44 \times\left(R_{S}+150\right)^{-0,338}
\end{gathered}
$$

onde $A$ e $B$ são parâmetros internos da correlação.

$$
\mu_{o}(c p)=A \mu_{d o}^{B}
$$

A viscosidade da água $\left(\mu_{w}\right)$ foi considerada constante e igual a $1 \mathrm{cp}$.

O Fator de compressibilidade do gás $\left(Z_{g a s}\right)$ está relacionado com a variação de volume de um determinado volume de gás devido à mudança nas condições de pressão e temperatura. Nas Equações (40) a (48) está descrito o método de cálculo dessa propriedade.

$$
\begin{gathered}
p_{p c}=702,5-50 \gamma_{g} \\
T_{p c}=167+316,67 \gamma_{g} \\
p_{p r}=\frac{p}{p_{p c}}
\end{gathered}
$$




$$
T_{p r}=\frac{T}{T_{p c}}
$$

onde $p_{p c}$ é a pressão pseudo crítica, $T_{p c}$ é a temperatura pseudo crítica, $p_{p r}$ é a pressão pseudo reduzida, $T_{p r}$ é a temperatura pseudo reduzida .

Da Equação (44) à Equação (47) os cálculos são realizados em um loop cujo critério de parada é que o erro seja $>0,001$. O valor inicial de $Z$ é 1 .

$$
\rho_{p r}=0,27 \frac{p_{p r}}{Z \times T_{p r}}
$$

onde $\rho_{p r}$ é um parâmetro interno do sistema de equações.

$$
\begin{gathered}
Z_{1}=1+\left(\frac{A_{1}+A_{2}}{T_{p r}}+\frac{A_{3}}{T_{p r}{ }^{3}}\right) \rho_{p r}+\left(\frac{A_{4}+A_{5}}{T_{p r}}\right) \rho_{p r}{ }^{2}+\left(\frac{A_{5} A_{6} \rho_{p r}{ }^{5}}{T_{p r}}\right) \\
+\frac{A_{7} \rho_{p r}{ }^{2}}{T_{p r}{ }^{3}}\left(1 A_{8} \rho_{p r}{ }^{2}\right) e^{\left(-A_{8} \rho_{p r}{ }^{2}\right)}
\end{gathered}
$$

onde $A_{1}=0,31506237, A_{2}=-1,0467099, A_{3}=-0,57832729, A_{4}=0,53530771$, $A_{5}=-0,61232032, A_{6}=-0,10488813, A_{7}=0,68157001$ e $A_{8}=0,68446549$

$$
\begin{gathered}
\text { erro }=2\left|\left(\frac{Z-Z_{1}}{Z+Z_{1}}\right)\right| \\
Z=\frac{Z_{1}+Z}{2} \\
Z_{\text {gas }}=Z
\end{gathered}
$$

A viscosidade do gás $\left(\mu_{g}\right)$ diminui conforme a pressão diminui porque quanto menor a pressão, mais afastadas se tornam as moléculas do gás, tornando mais fácil o deslocamento em relação às outras moléculas os passos para o cálculo de $\mu_{\mathrm{g}}$ são apresentados da Equação (49) à Equação (54).

$$
M_{g}=28,964 \gamma_{g}
$$




$$
\begin{gathered}
\omega=\frac{\left(9,4+0,02 M_{g}\right) T\left({ }^{\circ} \mathrm{F}\right)^{1,5}}{209+19 M_{g} T\left({ }^{\circ} \mathrm{F}\right)} \\
x=3,5+\frac{986}{T\left({ }^{\circ} \mathrm{F}\right)}+0,01 M_{g} \\
y=2,4-0,2 x \\
\rho=\frac{1,4926 \times 10^{-3} p M_{g}}{Z_{g a s} \times T} \\
\mu_{g}(c P)=10^{-4}(\omega) e^{\left(x \rho^{y}\right)}
\end{gathered}
$$

onde $\omega, x, y$ e $\rho$ são parâmetros internos do sistema de equações.

A atração molecular que ocorre entre as moléculas na interface das fases produz um desequilíbrio de forças intermoleculares na interface. Esse desequilíbrio de forças é conhecido como tensão superficial $(\sigma$, dina/cm) e o procedimento de cálculo está descrito da Equação (55) à Equação (58)

$$
F_{C}=1-0,024 \times p^{0,045}
$$

onde $F_{c}$ é o fator de correção para $p \neq 14,7$ psi

$$
\sigma_{68}=39-0,2571 \times \gamma_{A P I}
$$

onde $\sigma_{68}$ é a fórmula para o cálculo da tensão superficial caso a temperatura in situ seja menor ou igual à $68^{\circ} \mathrm{F}\left(\mathrm{T}<=68^{\circ} \mathrm{F}\right)$.

$$
\sigma_{100}=37,5-0,2571 \times{ }^{\circ} A P I
$$

onde $\sigma_{100}$ é a fórmula para o cálculo da tensão superficial caso a temperatura in situ seja maior ou igual à $100^{\circ} \mathrm{F}\left(\mathrm{T}>=100^{\circ} \mathrm{F}\right)$. 


$$
\sigma_{(T)}=\sigma_{68}-\frac{(T-68) \times\left(\sigma_{68}-\sigma_{100}\right)}{32} \times F_{C}
$$

onde $\sigma_{(T)}$ é a fórmula para o cálculo da tensão superficial em qualquer temperatura.

O fator volume de formação do gás $\left(B_{g}\right)$, também conhecido como fator de expansão do gás, é definido como o volume de gás livre nas condições de subsuperfície necessário à produção de $1 \mathrm{ft}^{3}$ de gás na superfície e foi calculado conforme mostrado a seguir:

$$
B_{g}=\frac{14,7}{520} \times Z_{g a s} \times \frac{T\left({ }^{\circ} \mathrm{F}\right)+460}{P(p s i)}
$$

O gás que chega no tanque de estocagem é o gás que estava dissolvido no óleo adicionado ao gás que já se encontrava livre no reservatório. Uma vez que a $\mathrm{R}_{\mathrm{GL}}$ é a razão entre o volume total de gás e o volume total de líquido, ambos medidos na condição padrão, esse parâmetro pode ser multiplicado pela vazão total de líquido na superfície, Q, a fim de obter a vazão de gás na superfície $\left(Q_{g s t}\right)$, conforme Equação (60).

$$
Q_{g s t}=R_{G L} Q
$$

Ao longo da coluna de produção, a volume de líquido em cada ponto, e consequentemente a vazão, varia majoritariamente devido ao fato de que conforme a pressão vai diminuindo, gás sai de solução, diminuindo o volume do óleo. Logo, a vazão de líquido em determinada profundidade, ou seja, a vazão de líquido in situ $\left(Q_{l}\right)$ será a soma da vazão de água e a vazão de óleo, conforme Equação (61). Esta última pode ser obtida multiplicando-se a vazão de óleo nas condições padrão pelo fator de encolhimento $B_{o}$. Essa multiplicação "converterá" o volume da condição padrão para o volume na condição na região estudada.

$$
Q_{l}=Q_{w}+Q_{o s t} B_{o}
$$

onde $Q_{w}$ é a vazão de água in situ e $Q_{o s t}$ é o volume de óleo na condição padrão 
A vazão de gás in situ $\left(Q_{g}\right)$ pode ser obtida multiplicando a vazão de gás expresso em condições padrão pelo fator de encolhimento do gás, $B_{g}$, para obter a vazão no ponto de análise, conforme apresentado na eq. (62). $Q_{g s t}$ é o gás que chega na superfície. O termo $Q_{o s t} R_{s o}$ é a vazão de óleo vezes a razão de solubilidade, logo esse termo representa o gás que estava dissolvido. Ou seja, $\left(Q_{g s t}\right.$ - $\left.Q_{o s t} R_{s o}\right)$ representa o gás livre no ponto de análise.

$$
Q_{g}=\left(Q_{g s t}-Q_{o s t} R_{s o}\right) B_{g}
$$

O modelo Black Oil se baseia em uma variável chamada velocidade superficial. A velocidade superficial de uma fase é a velocidade que ela teria se escoasse sozinha pela seção transversal total da tubulação. Sendo assim, a velocidade superficial do líquido $\left(v_{s l}\right)$ é definida como sendo a razão entre a vazão de líquido (óleo + água) in situ $\left(Q_{l}\right)$ e a área transversal da tubulação, conforme Equação (63). Analogamente, a Velocidade superficial do gás $\left(v_{s g}\right)$ é calculada dividindo a vazão de gás in situ $\left(Q_{g}\right)$ pela área da tubulação, conforme Equação (64).

$$
\begin{aligned}
& v_{s l}=\frac{Q_{l}}{A} \\
& v_{s g}=\frac{Q_{g}}{A}
\end{aligned}
$$

A velocidade da mistura $\left(\mathrm{v}_{\mathrm{m}}\right)$ é a soma das velocidades superficiais:

$$
v_{m}=v_{s l}+v_{s g}
$$

Quando o óleo contém gás dissolvido, é chamado de Óleo vivo. Na condição padrão, quando já não há gás dissolvido, o óleo é chamado de óleo morto. A massa específica do óleo morto $\left(\rho_{\mathrm{do}}\right)$, é calculada por:

$$
\rho_{d o}=\gamma_{o} \rho_{w}
$$

onde $\gamma_{o}$ é a densidade do óleo e $\rho_{w}$ é a massa específica da água 
A Massa específica do gás na superfície $\left(\rho_{\mathrm{gst}}\right)$ pode ser encontrada dada a sua relação com a massa específica do ar:

$$
\rho_{g s t}=\gamma_{g} \rho_{a r}
$$

onde $\gamma_{g}$ é a densidade do gás e $\rho_{a r}$ é a massa específica do ar

A massa específica do líquido in situ $\left(\rho_{l}\right)$ é calculada através da definição básica de massa específica, ou seja, dividindo-se massa pelo volume. No numerador somam-se as massas de óleo e água presentes na célula por segundo e no denominador o volume total de líquido na célula por segundo

$$
\rho_{l}=\frac{\rho_{d o} Q_{o s t}+R_{s o} Q_{o s t} \rho_{g}+\rho_{w} Q_{w}}{B_{o} Q_{o s t}+Q_{w}}
$$

onde $\rho_{d o}$ é a massa específica do óleo morto, $Q_{o s t}$ é a vazão de óleo na condição padrão, $R_{s o}$ é a solubilidade do gás no óleo, $\rho_{g}$ é a massa específica do gás in situ, $\rho_{w}$ é a massa específica da água, $Q_{w}$ a vazão de água in situ e $B_{o}$ é fator volume de formação do óleo.

A massa específica do óleo in situ $\left(\rho_{\mathrm{o}}\right)$ é calculada por:

$$
\rho_{o}=\frac{\rho_{d o}+R_{s o} \rho_{g s t}}{B_{o}}
$$

onde $\rho_{g s t}$ é a massa específica do gás na condição padrão

A massa específica do gás in situ $\left(\rho_{\mathrm{g}}\right)$ é calculada a partir da equação de estado dos gases:

$$
p V=Z n R T
$$


onde $p$ é a pressão, $V$ é o volume ocupado pelo gás, $Z$ é o fator de compressibilidade, $n$ é o número de mols, $R$ é a constante universal dos gases e $T$ é a temperatura.

Porém

$$
n=\frac{m}{M_{g}}
$$

onde $m$ é a massa de gás que ocupa o volume e $M_{g}$ é a massa molar do gás

Substituindo $n$ conforme Equação (71) na Equação (70) e em seguida $M_{g}$, conforme Equação (14) obtemos a Equação (72)

$$
p V=\frac{m Z R T}{\gamma_{g} M_{a r}}
$$

onde $M_{a r}$ é a massa molar do ar e $\gamma_{g}$ é a densidade do gás

Isolando $\frac{m}{V}$, obtém-se a expressão para o cálculo da massa específica do gás $\left(\rho_{g}\right)$ :

$$
\rho_{g}=\frac{p \gamma_{g} M_{a r}}{Z R T}
$$

A viscosidade da fase líquida $\left(\mu_{l}\right)$ é calculada através de uma média ponderada das viscosidades do óleo $\left(\mu_{o}\right)$ e da água $\left(\mu_{w}\right)$ :

$$
\mu_{l}=\mu_{w} f_{w} \mu_{o}^{\left(1-f_{w}\right)}
$$

onde $f_{w}$ é o corte de água no poço.

Uma característica importante observada no escoamento interior a uma coluna de produção de petróleo é o que ocorre devido ao gás ser menos denso e menos viscoso que o líquido, provocando assim uma velocidade maior dessa fase, 
condição conhecida como escorregamento (velocidade in situ do gás maior do que a velocidade do líquido). Assim, o gás passa a ocupar uma fração menor do duto, considerando-se uma seção transversal. O parâmetro que representa a fração de líquido in situ é o holdup de líquido $\left(\mathrm{H}_{\mathrm{L}}\right)$.

$\mathrm{O}$ método utilizado para estimar o $\mathrm{H}_{\mathrm{L}}$ nessa pesquisa será o método de Hagedorn \& Brown modificado que é um modelo empírico correlacional para escoamentos que envolvem líquidos e gases, baseado no trabalho original de Hagedorn \& Brown (1965). As modificações com relação ao método original incluem o uso do holdup sem escorregamento $(\lambda)$ como parâmetro e o uso da correlação de Griffith e Wallis (1961) no caso do regime de escoamento em bolhas. O procedimento de cálculo é mostrado a seguir, da Equação (75) até a Equação (84).

$1^{\circ}$ ) Calcula-se o holdup de gás sem escorregamento $\left(\lambda_{\mathrm{g}}\right)$, ou seja, o holdup considerando-se que gás e líquido viajam à mesma velocidade:

$$
\lambda_{g}=\frac{v_{s g}}{v_{m}}
$$

onde $v_{s g}$ é a velocidade superficial do gás e $v_{m}$ é a velocidade da mistura

$2^{\circ}$ ) Calcula-se o parâmetro $L_{B}$, definido por:

$$
L_{B}=1,071-0,2218 \frac{v_{m}^{2}}{d}
$$

onde $L_{B}$ é um parâmetro de decisão interno do método de Hagedorn e Brown modificado.

Se $\lambda_{g}<L_{B}$ : usa-se a correlação de Griffith, apresentada nas Equações (77) e (78), para o cálculo do $H_{L}$.

$$
v_{s}=0,8 \frac{f t}{s}
$$




$$
H_{L}=1-\frac{1}{2} \times\left[1+\frac{v_{m}}{v_{s}}-\left(\left(1+\frac{v_{m}}{v_{s}}\right)^{2}-4 \times \frac{v_{s g}}{v_{s}}\right)^{1 / 2}\right]
$$

Observação: caso o valor calculado para $L_{B}$ seja menor ou igual a 0,13 ; adota-se $L_{B}$ igual a 0,13 . Ou seja, Se $L_{B} \leq 0,13 \rightarrow L_{B}=0,13$.

Se $\lambda_{\mathrm{g}}>\mathrm{L}_{\mathrm{B}}$, usa-se a correlação de Hagedorn \& Brown original para o cálculo do $\mathrm{H}_{\mathrm{L}}$. $\mathrm{O}$ cálculo do $\mathrm{H}_{\mathrm{L}}$ pela correlação de Hagedorn \& Brown consiste na execução dos passos descritos a seguir.

A expressão para a equação do balanço de energia mecânica utilizada no método é:

$$
\frac{d p}{d z}=\rho_{m} g+\frac{2 f \rho_{m} v_{m}^{2}}{d}+\rho_{m} \frac{\Delta\left(v_{m}^{2} / 2\right)}{\Delta z}
$$

onde $d p / d z$ é a perda de carga por comprimento de tubulação em psi/ft, $\rho_{m}$ é a massa específica da mistura, $g$ é a aceleração da gravidade, $f$ é o fator de fricção e $d$ é o diâmetro interno do escoamento.

Na Equação (79), o termo $\rho_{m} g$ representa a componente hidrostática da perda de carga, que fisicamente é a influência do peso da coluna de líquido acima do volume de controle estudado. O termo $\frac{2 f \rho_{m} v_{m}{ }^{2}}{d}$ representa a componente friccional da perda de carga, ou seja, a perda de energia devido à interação do fluido com as paredes da tubulação. O termo $\rho_{m} \frac{\Delta\left(v_{m}{ }^{2} / 2\right)}{\Delta z}$ é a componente da perda de carga devido às forças de aceleração.

O holdup de líquido $\left(H_{L}\right)$, necessário para o cálculo da massa específica da mistura, é obtido a partir de gráficos, utilizando os números adimensionais descritos a seguir:

$$
N_{v l}=\sqrt[4]{\left(\frac{\rho_{l}}{g \sigma}\right)}
$$


onde $N_{v l}$ é o número adimensional de velocidade do líquido, $g$ é a aceleração da gravidade, $\sigma$ é a tensão superficial e $\rho_{l}$ é a massa específica do líquido.

$$
N_{v g}=v_{s g} \sqrt[4]{\left(\frac{\rho_{l}}{g \sigma}\right)}
$$

onde $N_{v g}$ é o número adimensional de velocidade do gás.

$$
N_{d}=d \sqrt{ }\left(\frac{\rho_{l} g}{\sigma}\right)
$$

onde $N_{d}$ é o número adimensional de diâmetro.

$$
N_{l}=\mu_{l} \sqrt[4]{ }\left(\frac{g}{\rho_{l} \sigma^{3}}\right)
$$

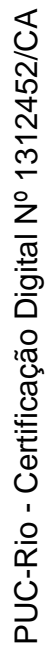

onde $N_{l}$ é o número adimensional de viscosidade do líquido e $\mu_{l}$ é a viscosidade da fase líquida

$3^{\circ}$ ) Obtém-se $\mathrm{C}_{\mathrm{NL}}$ a partir do gráfico da Figura 9Figura 9-Gráfico para obtenção do adimensional $\mathrm{C}_{\mathrm{NL}}$

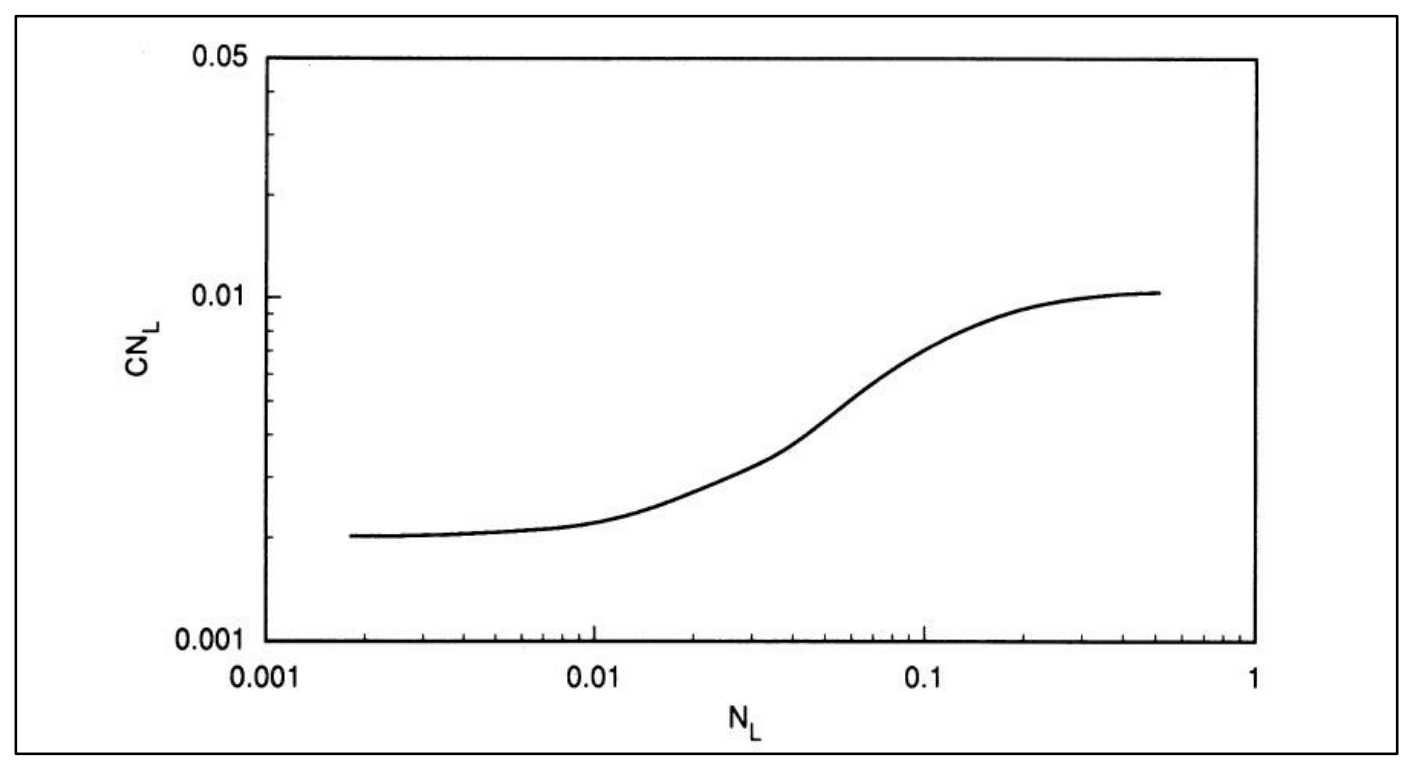

Figura 9-Gráfico para obtenção do adimensional $\mathrm{C}_{\mathrm{NL}}$ (Economides et al,, 1994) 
$4^{\circ}$ ) Calcula-se o valor de $\frac{\mathrm{N}_{\mathrm{vl}} \mathrm{P}^{0,1} \mathrm{C}_{\mathrm{NL}}}{\mathrm{N}_{\mathrm{vg}}{ }^{0,575} \mathrm{p}^{0,1} \mathrm{~N}_{d}}$ onde $p_{a}$ é a pressão atmosférica.

$5^{\circ}$ ) Obtém-se o adimensional $\frac{\mathrm{H}_{\mathrm{L}}}{\Psi}$ da Figura 10

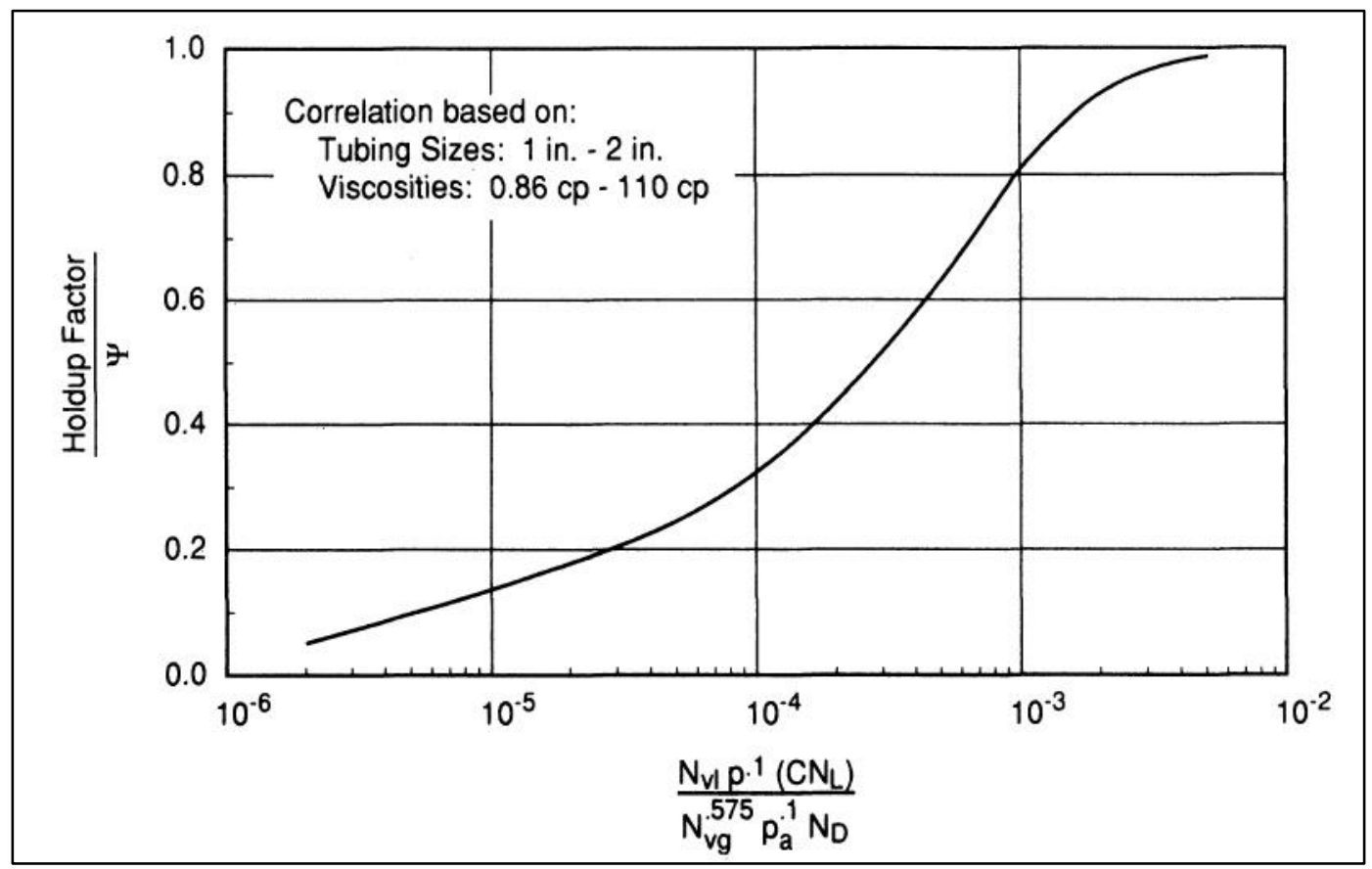

Figura 10 - Gráfico para obtenção de $\frac{H_{L}}{\Psi}$ (Economides et al., 1994)

$6^{\circ}$ ) Calcula-se o valor numérico de $\frac{\mathrm{N}_{\mathrm{vg}} \mathrm{N}_{\mathrm{l}}{ }^{0,38}}{\mathrm{~N}_{\mathrm{d}}{ }^{2,14}}$

$7^{\circ}$ ) Obtém-se o adimensional $\Psi$ através do gráfico apresentado na Figura 11 


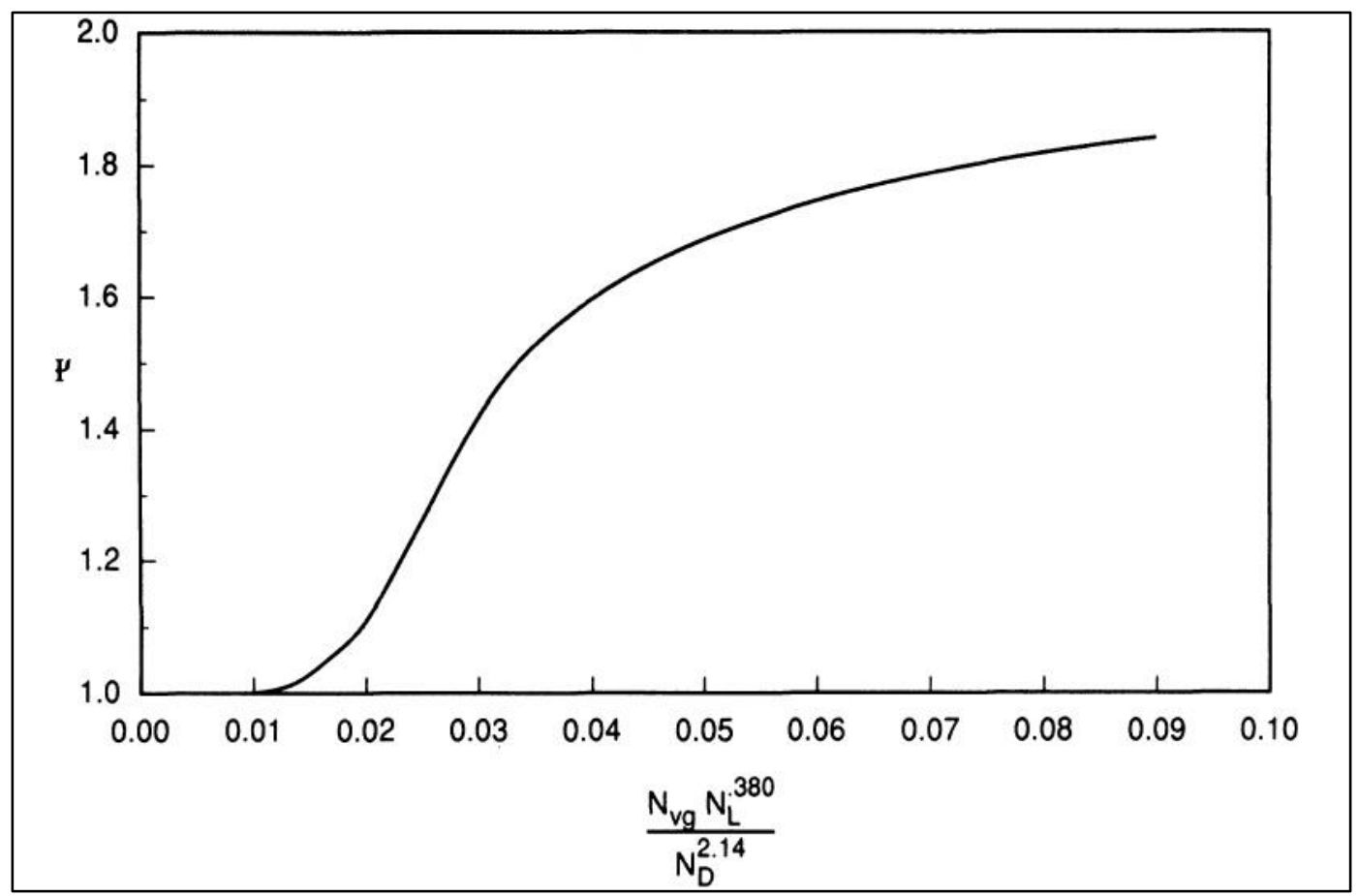

Figura 11- Gráfico para obtenção de $\Psi$ (Economides et al,, 1994)

$8^{\circ}$ ) Calcula-se $\mathrm{H}_{\mathrm{L}}$

$$
H_{L}=\frac{H_{L}}{\Psi} \times \Psi
$$

Observação: Para cada gráfico apresentado da Figura 9 até a Figura 11, foi feito um ajuste de curvas e obtida uma expressão para a relação entre as grandezas. A rotina em VBA foi desenvolvida de forma que, ao invés de fazer a leitura no gráfico, utiliza-se os valores através das equações.

Com o conhecimento do $\mathrm{H}_{\mathrm{L}}$, é possível calcular a Massa específica da mistura $\left(\rho_{\mathrm{m}}\right)$, que leva em consideração a quantidade de gás e de líquido da mistura, através de uma ponderação:

$$
\rho_{m}=\rho_{l} \times H_{L}+\rho_{g} \times H_{g}
$$

onde $H_{g}$ é o holdup de gás e é definido pela Equação (86)

$$
H_{g}=1-H_{L}
$$


Analogamente a Viscosidade da mistura $\left(\mu_{m}\right)$ é calculada por:

$$
\mu_{m}=\mu_{l}^{H_{L}} \times \mu_{g}{ }^{H_{g}}
$$

O fator de fricção $(f)$ é um parâmetro adimensional que é utilizado para calcular a perda de carga em uma tubulação devida ao atrito. Esse parâmetro é baseado no número de Reynolds $\left(R_{e}\right)$ é um número adimensional usado em mecânica dos fluidos para estimativa do regime de escoamento de determinado fluido sobre uma superfície. O Número de Reynolds permite avaliar a estabilidade do fluxo, indicando se o fluido escoa de forma laminar ou turbulenta, da seguinte forma: se $R_{e}$ for menor que 2300, o regime é considerado laminar e se $R_{e}$ for maior que 2300, é considerado turbulento. O número de Reynolds é obtido através do quociente entre forças de inércia e forças de viscosidade.

$$
R_{e}=\frac{\rho_{m} v_{m} d}{\mu_{m}}
$$

onde $\mu_{\mathrm{m}}$ é a viscosidade da mistura

O fator de fricção $(f)$ foi calculado através da equação de Chen (Chen, 1979), conforme o critério descrito a seguir:

Caso o escoamento seja Laminar, calcula-se f conforme a Equação (89).

$$
f=\frac{16}{R_{e}}
$$

Caso o escoamento seja turbulento, calcula-se $f$ conforme a Equação (90):

$$
f=\left(\frac{1}{A^{\prime}}\right)^{2}
$$

onde $A$ 'é um parâmetro interno do método de cálculo e é dado por:

$$
A^{\prime}=-4 \times\left[\log \left(\frac{e / d}{3,7065}-\frac{5,0452}{R e} \times \log \left(\frac{e / d}{2,8257}\right)+\left(\frac{7,149}{R e}\right)^{0,8981}\right)\right]
$$


A perda de carga $(\Delta \mathrm{P})$ no trecho é calculada através da Equação (92) que é o balanço de energia apresentado na Equação (79), porém sem o termo da perda de carga devido à forças de aceleração. Este termo de aceleração pode ser negligenciado, pois só é significativo se há grandes variações de velocidade, como quando há expansão excessiva do gás (escoamento anular) ou variação de diâmetro do tubo.

$$
\frac{\Delta p}{\Delta z}=\rho_{m} g+\frac{2 f \rho_{m} v_{m}^{2}}{d}+\rho_{m} \frac{\Delta\left(v_{m}^{2} / 2\right)}{\Delta z}
$$

Por fim, dado $\Delta p$, encontra-se o comprimento de tubulação da i-ésima célula, isolando-se $\Delta z$ na Equação (92).

$$
\Delta z_{i}=\frac{\Delta p}{\left.\frac{\Delta p}{\Delta z}\right|_{i}}=\frac{\Delta p}{\rho_{m} g+\left.\frac{2 f \rho_{m} v_{m}^{2}}{d}\right|_{i}}
$$

Para e atualização da temperatura (T) em cada célula foi utilizado o seguinte modelo simplificado:

$$
T=T_{i}+0,01 z
$$

onde $\mathrm{T}_{\mathrm{i}}$ é a temperatura inicial em ${ }^{\circ} \mathrm{F}$, e $\mathrm{z}$ é a profundidade.

\section{3.}

\section{Modelo Computacional}

Primeiramente foram desenvolvidas funções no VBA com as equações explicitadas no item 3.2, para o cálculo de cada parâmetro. Em seguida foi desenvolvida uma rotina principal que faz uso dessas funções para o cálculo das propriedades. O programa lê os dados de entrada da planilha em Excel, como mostrado na Figura 12, para prosseguir com os cálculos. 


\begin{tabular}{|c|c|c|c|c|c|}
\hline 4 & $\mathrm{~A}$ & $B$ & C & D & $E$ \\
\hline 1 & & \multicolumn{4}{|c|}{ CÁLCULO DAS PROPRIEDADES } \\
\hline 2 & & & & & \\
\hline 3 & & & & & \\
\hline 4 & & \multicolumn{3}{|c|}{ DADOS DE ENTRADA: } & \\
\hline 5 & & $Q$ & 800 & STB/dia & \\
\hline 6 & & d & 3,5 & in & \\
\hline 7 & & e & 0,00029 & in & \\
\hline 8 & & $\mathrm{rg}$ & 0,75 & - & \\
\hline 9 & & ${ }^{\circ} \mathrm{API}$ & 25 & $\cdot$ & \\
\hline 10 & & RGL & 0 a 1400 & scf/STB & \\
\hline 11 & & Tini & 100 & ${ }^{\circ} \mathrm{F}$ & \\
\hline 12 & & $\mathrm{Pt}$ & 250 & psia & \\
\hline 13 & & Hcolu & 6000 & $\mathrm{ft}$ & \\
\hline 14 & & $d p$ & 10 & psia & \\
\hline 15 & & J & 1 & (STBO/dia)/psi & \\
\hline 16 & & Pres & 3000 & psia & \\
\hline 17 & & linha & 10 & - & \\
\hline 18 & & $f w$ & 0,5 & - & \\
\hline
\end{tabular}

Figura 12 - Interface com o simulador: dados de entrada

A rotina principal, utilizada para simular com a Versão 1 do programa, encontra-se no ANEXO A. A expressão "Sub principal()" e a expressão "End Sub" são comandos que sinalizam o início e o fim da rotina, respectivamente. Cada comando da programação possui ao lado uma explicação em verde. No VBA, todos os caracteres precedidos pelo caractere ' ficam na cor verde e são processados como comentário pelo VBA que não atribui nenhuma ação a eles. É importante observar que não necessariamente as variáveis da planilha do Excel e as do programa são representadas pelo mesmo nome/símbolo. O importante é que o programador saiba bem o que significa e como será utilizada cada variável declarada na rotina.

Para iniciar a simulação, basta pressionar o botão azul na planilha do Excel, como mostrado na Figura 13. Também na Figura 13 é possível observar uma das tabelas geradas pela simulação, que por sua vez gera as curvas de gradiente de pressão, que é a tabela de pressão com as alturas calculadas correspondentes para cada célula, e isso para cada razão gás-líquido (RGL) estudada. O programa também gera, como os dados da tabela, para cada RGL, as curvas de IPR e TPR.

As funções desenvolvidas são baseadas nas equações mostradas na memória de cálculo e o nome da função é de escolha do programador, que determina também, ao criar a função, quais serão os parâmetros utilizados no cálculo. Esses parâmetros aparecem entre parênteses ao lado do nome da função. Nesse caso, 
cada parâmetro chamado pela função, tem que estar presente na rotina representado pelas mesmas letras/símbolos, ou seja, escrito de maneira idêntica.

Exemplo:

Pbolha $=$ prebolha $(g g, T, g A P I, R s b)$.

Está sendo declarada a variável Pbolha. O valor atribuído a essa variável será calculado pela função prebolha. Para executar o cálculo, essa função necessita das variáveis $g g, T, g A P I$ e $R s b$ que devem estar declaradas na rotina que chamou a função, escritas exatamente da mesma forma.

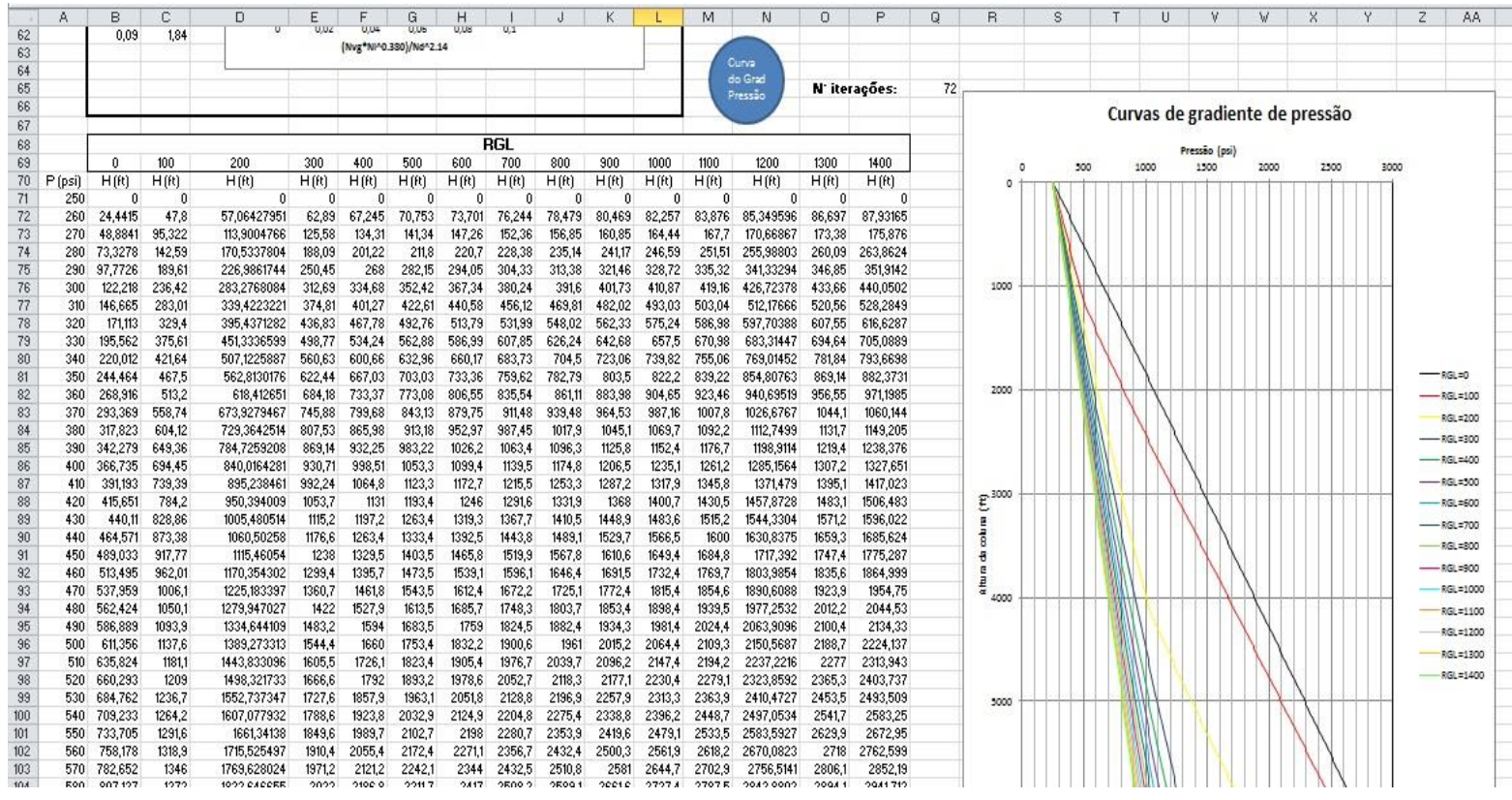

Figura 13 - Interface com o programa: botão de start e resultados.

\section{4.}

\section{Validação do programa}

Para a validação do programa foram geradas curvas de gradiente de pressão que foram comparadas com as curvas de gradiente de pressão de Gilbert. Gilbert (1954) construiu as curvas com dados experimentais de poços que produziam óleos com massa específica entre 825 e $964 \mathrm{Kg} / \mathrm{m}^{3}\left(15<{ }^{\circ} \mathrm{API}<40\right)$, porém, essas curvas também representam bem o comportamento de fluidos com massa específica fora dessa faixa. O gradiente de pressão depende fortemente do diâmetro, vazão, razão gás líquido e da pressão (Szilas, 1975). Para executar a 
simulação no programa, os valores utilizados de parâmetros como rugosidade interna do tubo e temperatura do reservatório foram valores que estão dentro da faixa dos valores comumente observados em geral nas atividades de produção. Os dados fornecidos para a simulação encontram-se na Tabela 2 e o resultado da simulação encontra-se na Figura 14.

Tabela 2 - Dados de entrada para a simulação para comparação com as curvas de Gilbert relativas a 400 barris/dia e diâmetro de 2,875 in

\begin{tabular}{ccc}
\hline Variável & Valor & Unidade \\
\hline $\mathrm{Q}$ & 400 & $\mathrm{STBO} / \mathrm{dia}$ \\
$\mathrm{d}$ & 2,875 & in \\
$\mathrm{e}$ & 0,00029 & in \\
$\gamma_{\mathrm{g}}$ & 0,75 & -- \\
$\gamma_{\mathrm{API}}$ & 25 & ${ }^{\circ} \mathrm{API}$ \\
$\mathrm{T}_{\text {ini }}$ & 100 & ${ }^{\circ} \mathrm{F}$ \\
$\mathrm{p}_{\mathrm{t}}$ & 14,7 & $\mathrm{psia}$ \\
$\mathrm{H}_{\text {colu }}$ & 6000 & $\mathrm{ft}$ \\
$\mathrm{dp}$ & 10 & psia \\
$\mathrm{p}_{\text {res }}$ & 2800 & psia \\
\hline
\end{tabular}

Legenda: $\mathrm{T}_{\text {ini }}=$ temperatura inicial, $\mathrm{H}_{\text {colu }}=$ profundidade da coluna, Pres=Pressão do reservatório, $\mathrm{dp}=$ passo na pressão

Para comparar as curvas geradas pelo simulador desenvolvido com as curvas de Gilbert, considerou-se uma profundidade de $6000 \mathrm{ft}$. Para cada RGL (de zero a 1400 scf/STB, com passo de 100 scf/STB), obteve-se a pressão correspondente a essa profundidade e comparou-se com as pressões encontradas pelas curvas de Gilbert, correspondente ao diâmetro de 2,875 in e vazão de 400 barris/dia (ANEXO B) para a mesma profundidade. Essa comparação está resumida na Tabela 3 . 
Tabela 3- Comparação entre as pressões encontradas pelo simulador desenvolvido e pelas curvas de Gilbert relativas à 400 barris/dia e 2,875 in de diâmetro.

\begin{tabular}{ccccc}
\hline $\begin{array}{c}\text { Profundidade } \\
(\mathrm{ft})\end{array}$ & $\begin{array}{c}\text { RGL } \\
(\mathrm{scf} / \mathrm{bbL})\end{array}$ & $\begin{array}{c}\text { Pressão } \\
\text { encontrada pela } \\
\text { curva de Gilbert } \\
(\mathrm{psi})\end{array}$ & $\begin{array}{c}\text { Pressão } \\
\text { encontrada pelo } \\
\text { simulador } \\
\text { desenvolvido(psi) }\end{array}$ & $\begin{array}{c}\text { Diferença } \\
(\%)\end{array}$ \\
\hline 6000 & 0 & 2250 & 2307 & 2,5 \\
6000 & 100 & 1500 & 1934 & 28,9 \\
6000 & 200 & 1200 & 1352 & 12,7 \\
6000 & 300 & 1000 & 853 & 14,7 \\
6000 & 400 & 900 & 776 & 13,8 \\
6000 & 600 & 750 & 694 & 7,5 \\
6000 & 800 & 650 & 651 & 0,2 \\
6000 & 1000 & 600 & 624 & 4,0 \\
6000 & 1200 & 500 & 607 & 21,4 \\
6000 & 1400 & 480 & 595 & 24,0 \\
\hline
\end{tabular}
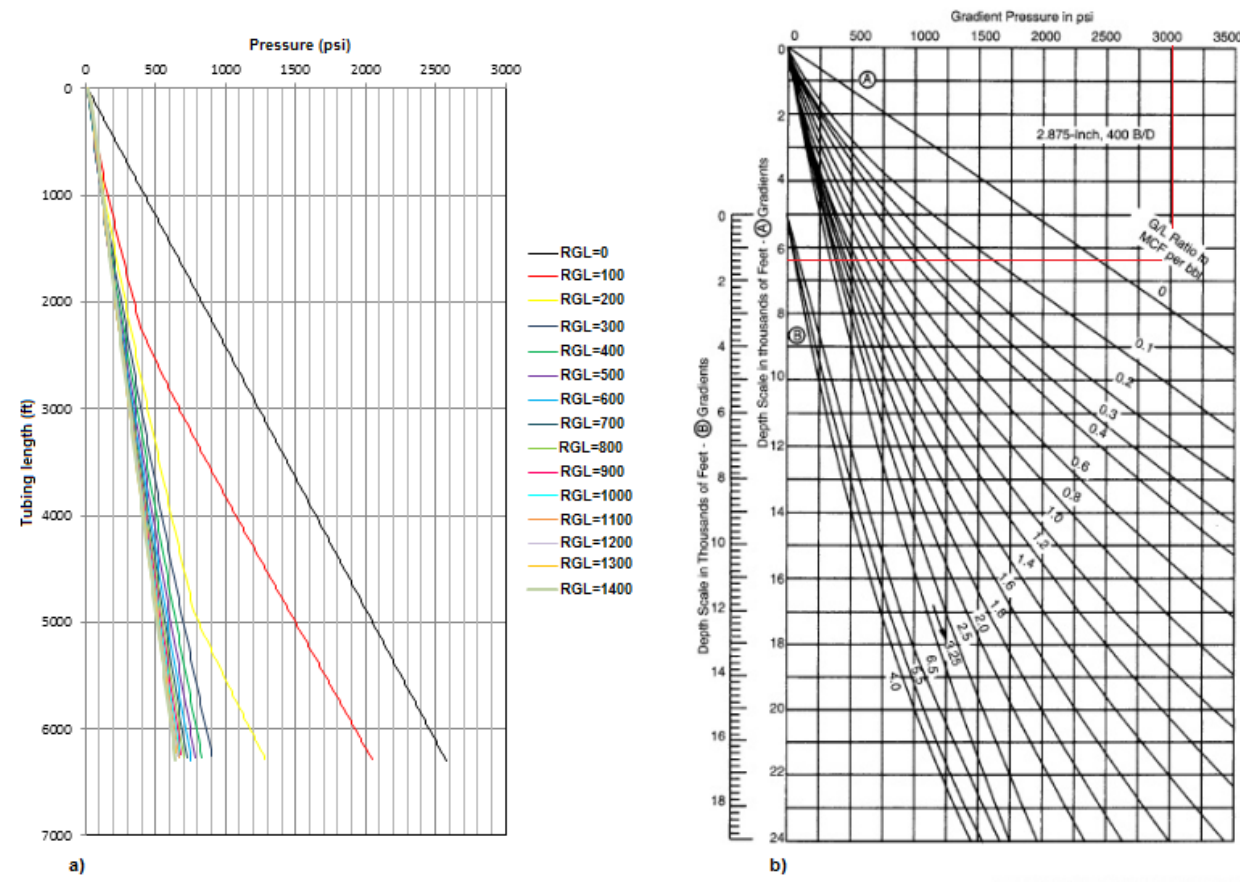

Figura 14- (a) Curvas de gradiente de pressão obtidas pelo simulador desenvolvido (b) Curvas de Gilbert para comparação reproduzido de Gilbert (1954)

De acordo com os resultados apresentados, é possível observar que ambas as curvas apresentam a mesma tendência: quanto maior a RGL, maior a inclinação da curva e, portanto, menor o gradiente de pressão. 
Na comparação dos valores absolutos, deve ser levado em consideração que as curvas de Gilbert são um comportamento aproximado de distribuição de pressão, baseado em dados experimentais, que abrangem uma larga faixa de óleos, com grau API entre 15 e 40, e essa variável produz uma diferença significativa nos valores de pressão encontrados. O valor do grau API utilizado, foi um valor próximo ao valor médio dessa faixa e os valores obtidos possuem a mesma ordem de grandeza. Sendo assim, os resultados podem ser considerados compatíveis. 


\section{4}

\section{Análise dos resultados}

\section{1.}

\section{Curvas de gradiente de pressão}

Executou-se, com a versão 1 do programa, a simulação para as condições da Tabela 4 (dados de entrada) e obteve-se, para cada RGL, uma tabela com as pressões e as alturas hidrostáticas correspondentes. A partir dessa tabela, obtevese as curvas de gradiente de pressão apresentadas na Figura 15- Curvas de gradiente de pressão obtidas pela simulação nas condições da Tabela 4Figura 15.

Tabela 4 - Dados de entrada da simulação.

\begin{tabular}{|c|c|c|}
\hline Variável & Valor & Unidade \\
\hline$Q$ & 300 & STBO/dia \\
\hline $\mathrm{d}$ & 2 & in \\
\hline $\mathrm{e}$ & 0,000288 & in \\
\hline$\gamma_{\mathrm{g}}$ & 0,75 & -- \\
\hline${ }^{\circ} \mathrm{API}$ & 30 & ${ }^{\circ} \mathrm{API}$ \\
\hline $\mathrm{T}_{\mathrm{ini}}$ & 120 & ${ }^{\circ} \mathrm{F}$ \\
\hline $\mathrm{p}_{\mathrm{t}}$ & 250 & psia \\
\hline $\mathrm{H}_{\text {colu }}$ & 6000 & $\mathrm{ft}$ \\
\hline $\mathrm{dp}$ & 10 & psia \\
\hline $\mathrm{J}$ & 1 & $(\mathrm{STBO} / \mathrm{dia}) / \mathrm{psi}$ \\
\hline $\mathrm{p}_{\text {res }}$ & 2500 & psia \\
\hline$f_{w}$ & 0,2 & -- \\
\hline
\end{tabular}

Como é possível observar na Figura 15 , a curva para $\mathrm{RGL}=0$ é uma reta. Isso se explica pelo fato de se ter adotado uma hipótese de líquido incompressível, de modo que a massa específica não varia com a profundidade. Além disso, a perda de carga unitária é constante ao longo da profundidade. 


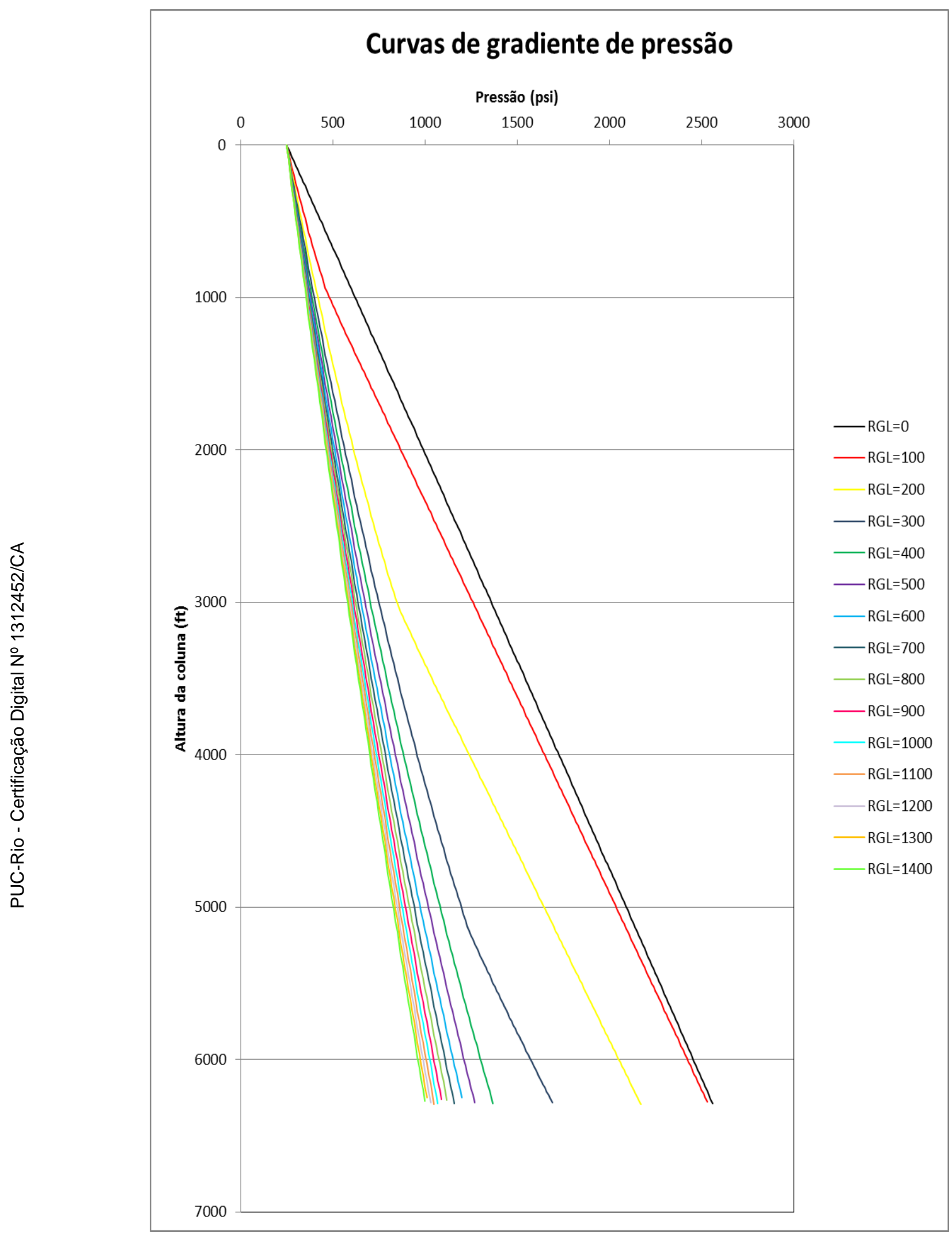

Figura 15- Curvas de gradiente de pressão obtidas pela simulação nas condições da Tabela 4 


\section{2. \\ Determinação da pressão no fundo do poço $\left(p_{\mathrm{wf}}\right)$}

Através das curvas apresentadas na Figura 15 é possível obter a pressão no fundo do poço, $\mathrm{p}_{\mathrm{wf}}$, que é a pressão na profundidade $\mathrm{H}_{\text {colu }}$, neste caso, $6000 \mathrm{ft}$. Supondo que queremos avaliar um poço cuja RGL seja $600 \mathrm{scf} / \mathrm{STBO}$, podemos utilizar a curva relativa a essa RGL e vemos que, para $\mathrm{H}=6000 \mathrm{ft}$, a pressão é 1125 psi, ou seja, $p_{w f}=1125$ psi, para as condições descritas na Tabela 4 .

\section{3.}

Obtenção das curvas de IPR, TPR e vazão de produção do poço

Ainda para as condições da Tabela 4, executou-se várias vezes a simulação, modificando-se apenas a vazão. Para cada vazão, obteve-se, pela curva correspondente à RGL=600 scf/STBO, da Figura 15, a pressão de fundo do poço em fluxo $\left(\mathrm{p}_{\mathrm{wf}}\right)$. Com esses dados foi possível gerar a curva de TPR do poço mostrada na Figura 16. No mesmo gráfico incluiu-se a curva de IPR, que pôde ser montada com os dados de entrada e através da Equação (94), derivada da Equação (7).

$$
Q=J\left(p_{e}-p_{w f}\right)
$$

Através da Figura 16, é possível determinar a vazão real do poço, que é o ponto onde as duas curvas se cruzam, ou seja, a vazão de produção seria de aproximadamente $1000 \mathrm{STBO} / \mathrm{dia}$, para as condições fornecidas. 


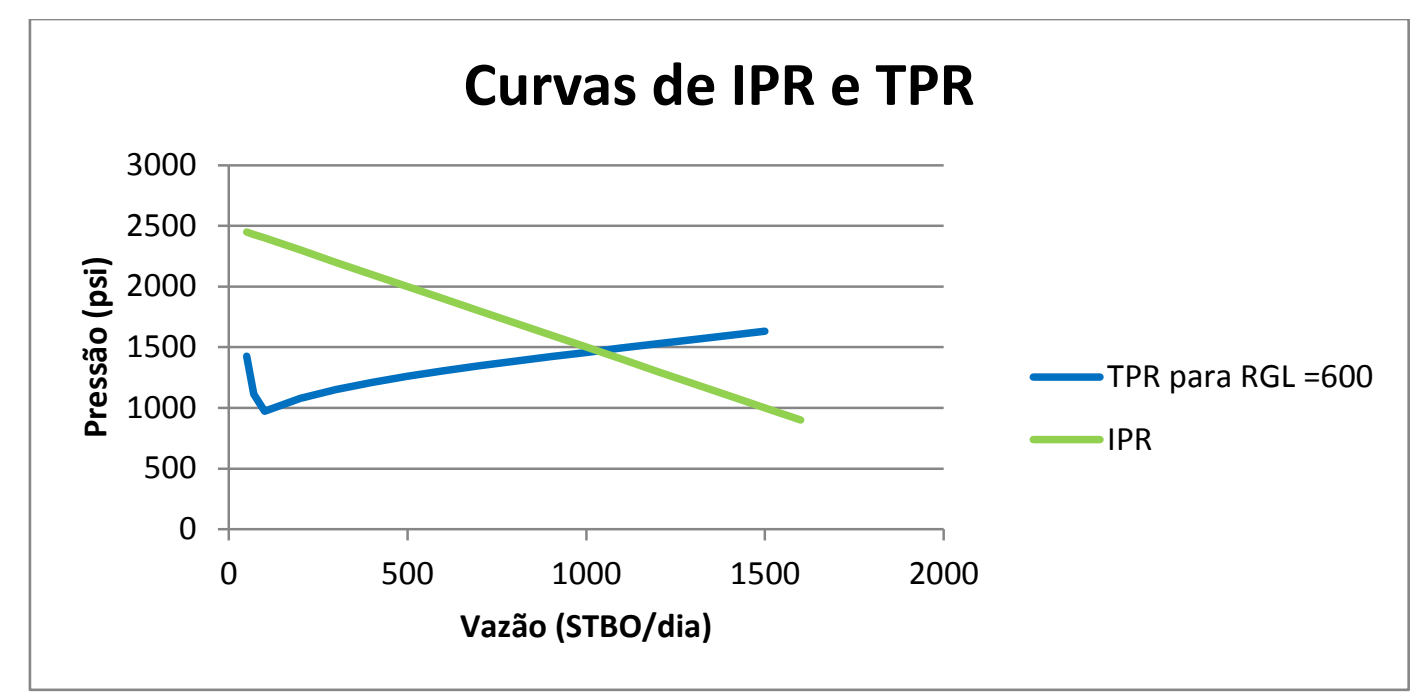

Figura 16- Curvas de IPR e TPR para as condições da Tabela 4.

\section{4. Influência da pressão do reservatório na vazão de produção}

Caso a pressão do reservatório seja aumentada para 3000 psi, mantendo todos os outros parâmetros constantes, como mostrado na Tabela 5, obtém-se o resultado apresentado Figura 17, que mostra que, nesse caso, a vazão de produção do reservatório seria ampliada para $1400 \mathrm{STBO} /$ dia. Isso mostra que, quanto maior a pressão do reservatório, maior a vazão. Isso faz sentido, pois o diferencial de pressão é a força motriz do processo e, quanto maior a pressão do reservatório, maior o diferencial de pressão e logo, maior a força motriz.

$$
\Delta p=p_{e}-p_{w f}
$$

Tabela 5- Dados de entrada para a simulação, com alteração apenas da pressão do reservatório.

\begin{tabular}{ccc}
\hline Variável & Valor & Unidade \\
\hline $\mathrm{Q}$ & 300 & $\mathrm{STBO} / \mathrm{dia}$ \\
$\mathrm{d}$ & 2 & in \\
$\mathrm{e}$ & 0,000288 & in \\
$\gamma_{\mathrm{g}}$ & 0,75 & -- \\
${ }^{\circ} \mathrm{API}$ & 30 & ${ }^{\circ} \mathrm{API}$ \\
$\mathrm{T}_{\text {ini }}$ & 120 & ${ }^{\circ} \mathrm{F}$ \\
\hline
\end{tabular}




\begin{tabular}{ccc}
\hline $\mathrm{p}_{\mathrm{t}}$ & 250 & $\mathrm{psia}$ \\
$\mathrm{H}_{\text {colu }}$ & 6000 & $\mathrm{ft}$ \\
$\mathrm{dp}$ & 10 & $\mathrm{psia}$ \\
$\mathrm{J}$ & 1 & $(\mathrm{STBO} / \mathrm{dia}) / \mathrm{psi}$ \\
$\mathrm{p}_{\mathrm{res}}$ & 3000 & $\mathrm{psia}$ \\
$\mathrm{f}_{\mathrm{w}}$ & 0,2 & -- \\
\hline
\end{tabular}

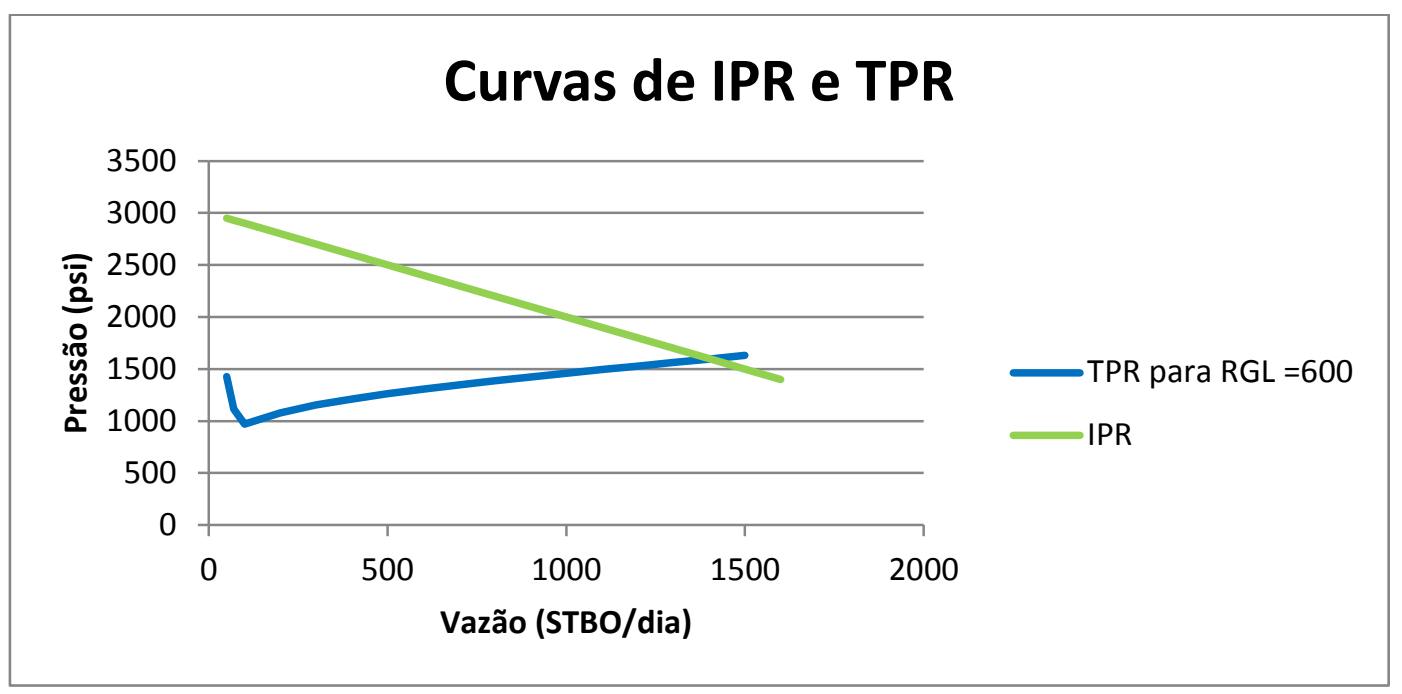

Figura 17- Curvas de IPR e TPR para as condições da Tabela 5

\section{5. \\ Determinação da RGL ótima e vazão de injeção de gás}

Ainda para as condições da Tabela 5, podemos incluir no gráfico as curvas de TPR, para várias RGLs, e avaliar qual delas intercepta a curva de IPR de forma a produzir com a maior vazão. Essas curvas encontram-se na Figura 18. A princípio observa-se uma tendência de que quanto maior a RGL, maior a vazão, pois quanto maior a quantidade de gás, menos densa se torna a mistura, diminuindo o componente hidrostático na equação da perda de carga, conforme a Equação (92). Porém ao se observar em detalhes a região onde as curvas de maior RGL cruzam com a IPR (Figura 19), observamos que a curva que cruza a IPR, produzindo com a maior vazão, não é a curva de maior RGL (1400 scf/STBO) e sim a curva de 1100 scf/STB. Logo, 1100 scf/STB é a RGL ótima. Isso ocorre porque, aumentando a vazão de gás, a velocidade do escoamento também aumenta 
e, consequentemente, o componente de fricção da perda de carga também aumenta, uma vez que a velocidade encontra-se elevada ao quadrado nesse termo. Ao prosseguir com o aumento da RGL, haverá um momento em que o aumento da perda de carga friccional se torna mais significativo do que a diminuição do componente hidrostático. Colocando num gráfico apenas as Curvas de IPR e TPR ótima, vemos que a vazão ótima de produção é 1480 STBO/dia (Figura 20).

Uma vez determinada a RGL ótima, é possível determinar a vazão de injeção ótima, que será a diferença entre a vazão ótima de gás e a vazão de gás pré-existente no poço. Ou seja:

$$
\begin{aligned}
& \text { RGL ótima }=1100 \frac{s c f}{S T B O} \times 1480 \frac{S T B O}{\text { dia }}=1628000 \frac{s c f}{d i a} \\
& \text { RGL poço }=600 \frac{s c f}{S T B O} \times 1480 \frac{S T B O}{\text { dia }}=888000 \frac{s c f}{d i a} \\
& \text { RGL injeção }=1628000-888000=740000 \frac{s c f}{d i a}
\end{aligned}
$$

Portanto, a vazão de gás de injeção contínua através da válvula de gás lift, para o caso estudado, deverá ser 740000 scf/dia. 


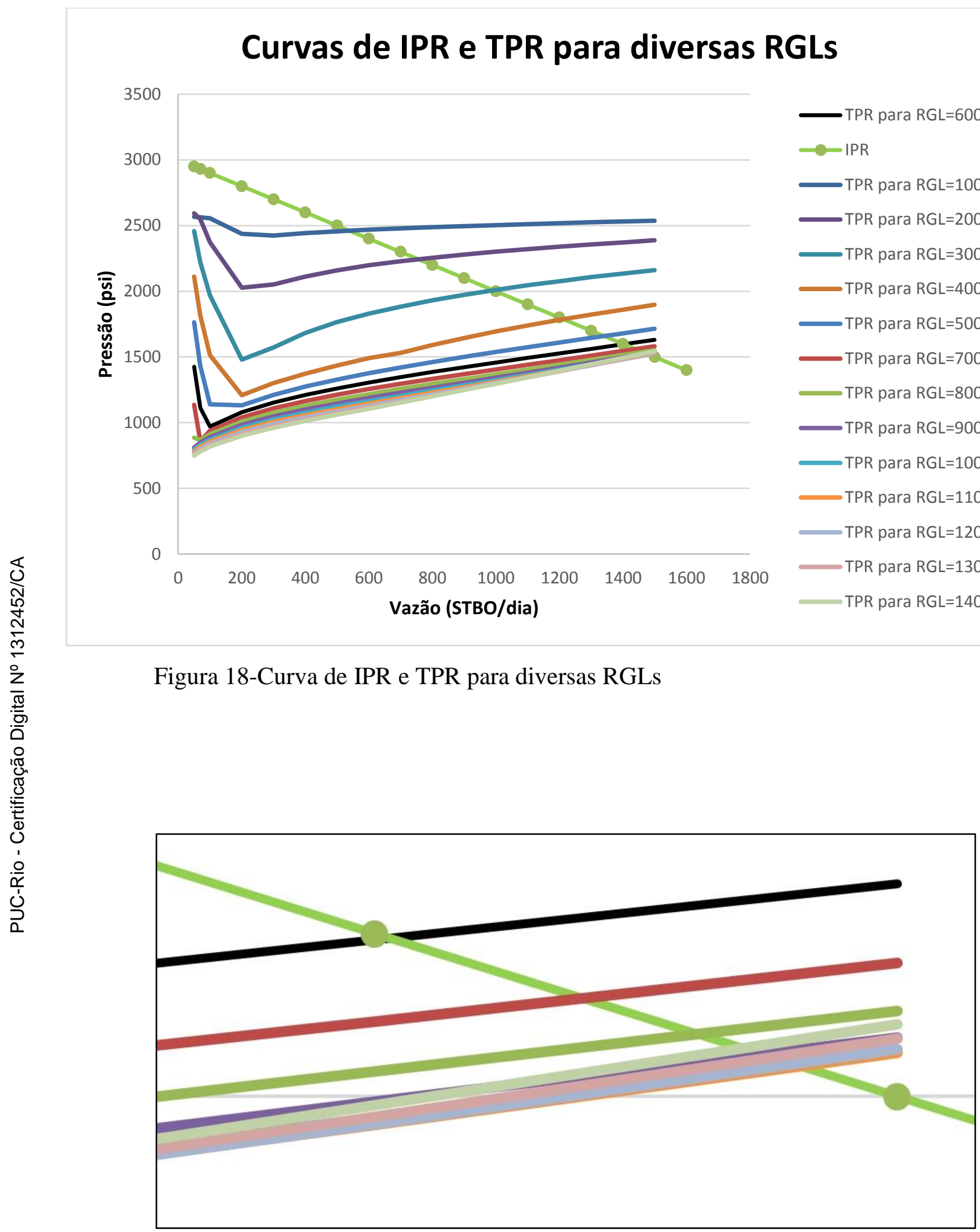

Figura 19 - Detalhe da Figura 18, onde é possível visualizar que as curvas se cruzam. A curva correspondente à $\mathrm{RGL}=1100 \mathrm{scf} / \mathrm{STBO}$ intercepta a curva e IPR de forma a produzir com a maior vazão. 


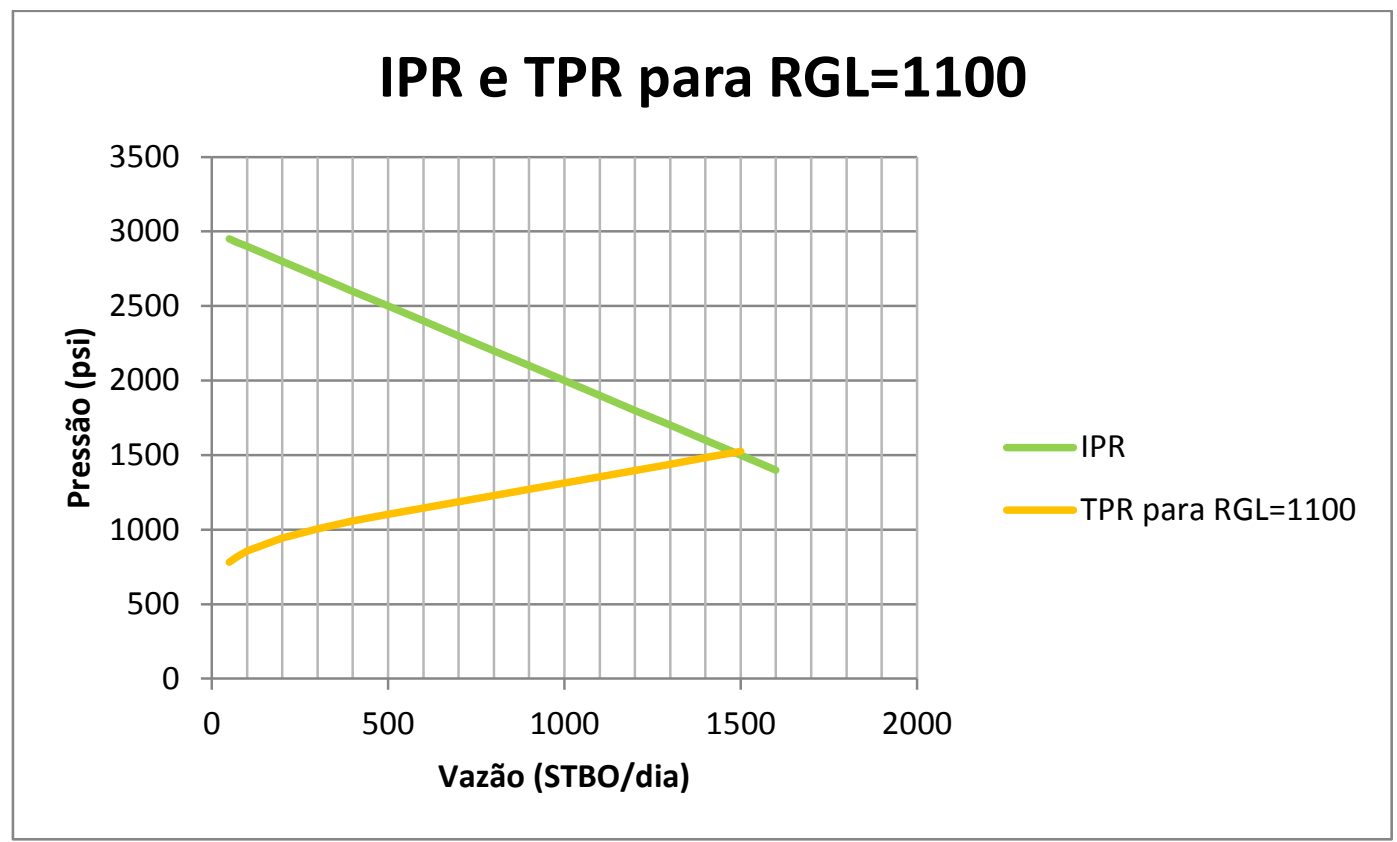

Figura 20 - Curva de IPR e TPR para RGL = 1100 scf/STBO.

\section{6.}

\section{Influência do diâmetro da coluna na vazão de produção}

Mantendo-se as mesmas condições da Tabela 5 (exceto o diâmetro), executou-se a simulação para valores de diâmetro variando de 1,5 a 3,5 in. $\mathrm{O}$ resultado pode ser visto na Figura 21. O resultado mostra que quanto maior o diâmetro da coluna, maior a vazão. De fato, quanto maior o diâmetro do escoamento, menor a perda de carga por fricção. 


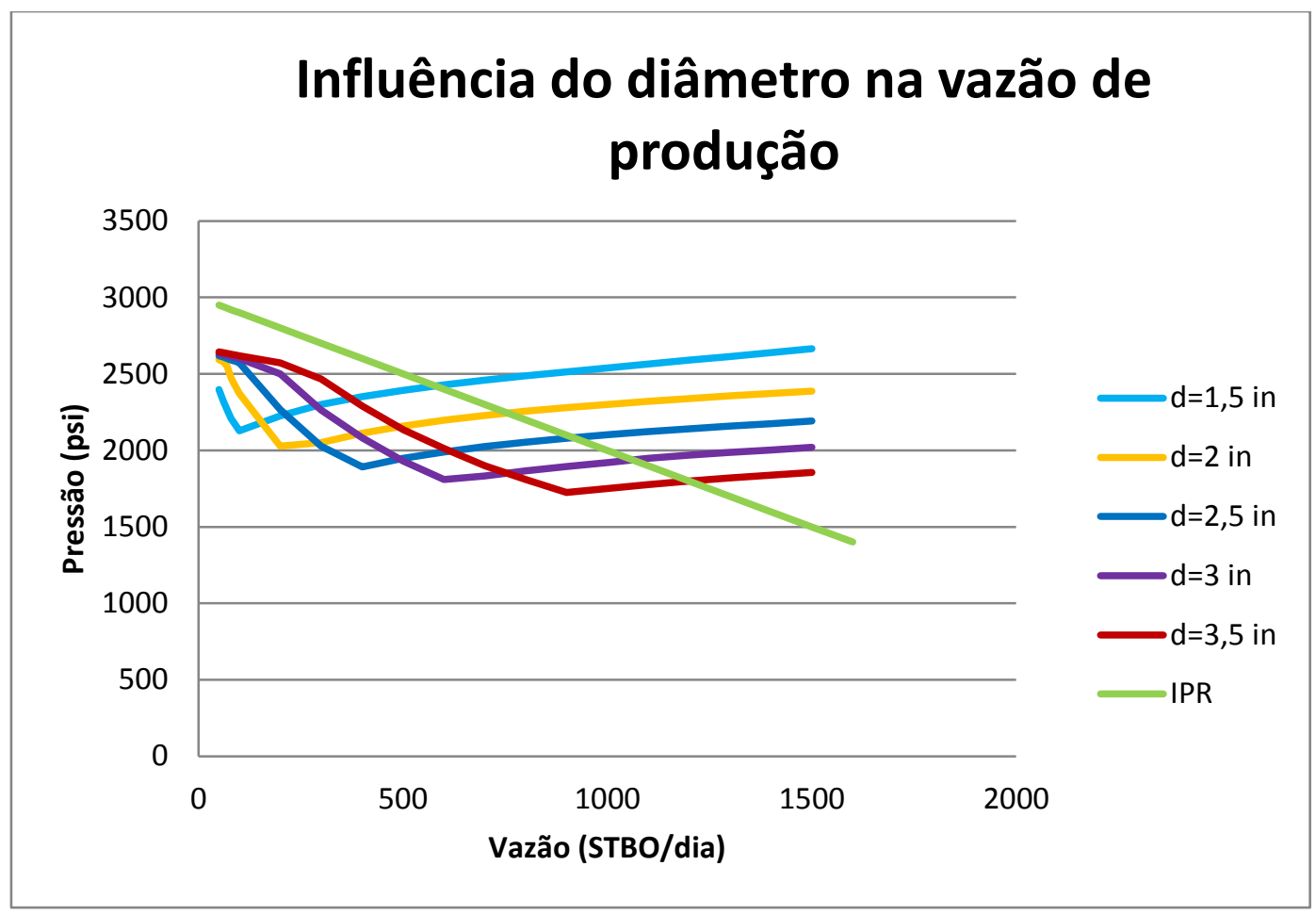

Figura 21- Influência do diâmetro da coluna na vazão de produção.

\section{7. \\ Determinação da pressão na cabeça do poço}

Usando a versão 2 do programa, foi feita a simulação para as condições da Tabela 6 (dados de entrada) e obteve-se para cada RGL, uma tabela com as pressões e a altura correspondente. Essa tabela gerou as curvas exibidas na Figura 22, que contêm as curvas obtidas.

Tabela 6 - Condições da simulação com a versão 2 do programa.

\begin{tabular}{ccc}
\hline Variável & Valor & Unidade \\
\hline $\mathrm{Q}$ & 800 & $\mathrm{STBO} / \mathrm{dia}$ \\
$\mathrm{d}$ & 2 & in \\
$\mathrm{e}$ & 0,000288 & in \\
$\mathrm{Vg}$ & 0,75 & -- \\
${ }^{\circ} \mathrm{API}=$ & 30 & ${ }^{\circ} \mathrm{API}$ \\
$\mathrm{gn}$ & 0,5 & $\mathrm{psi} / \mathrm{ft}$ \\
$\mathrm{T}_{\text {res }}=$ & 200 & $\mathrm{grau} \mathrm{F}$ \\
$\mathrm{P}_{\text {res }}=$ & 3000 & $\mathrm{psia}$ \\
$\mathrm{J}$ & 1 & $(\mathrm{STBO} / \mathrm{dia}) / \mathrm{psi}$ \\
$\mathrm{H}_{\text {colu }}=$ & 6000 & $\mathrm{ft}$ \\
$\mathrm{dP}$ & -10 & $\mathrm{Psia}$ \\
\hline
\end{tabular}




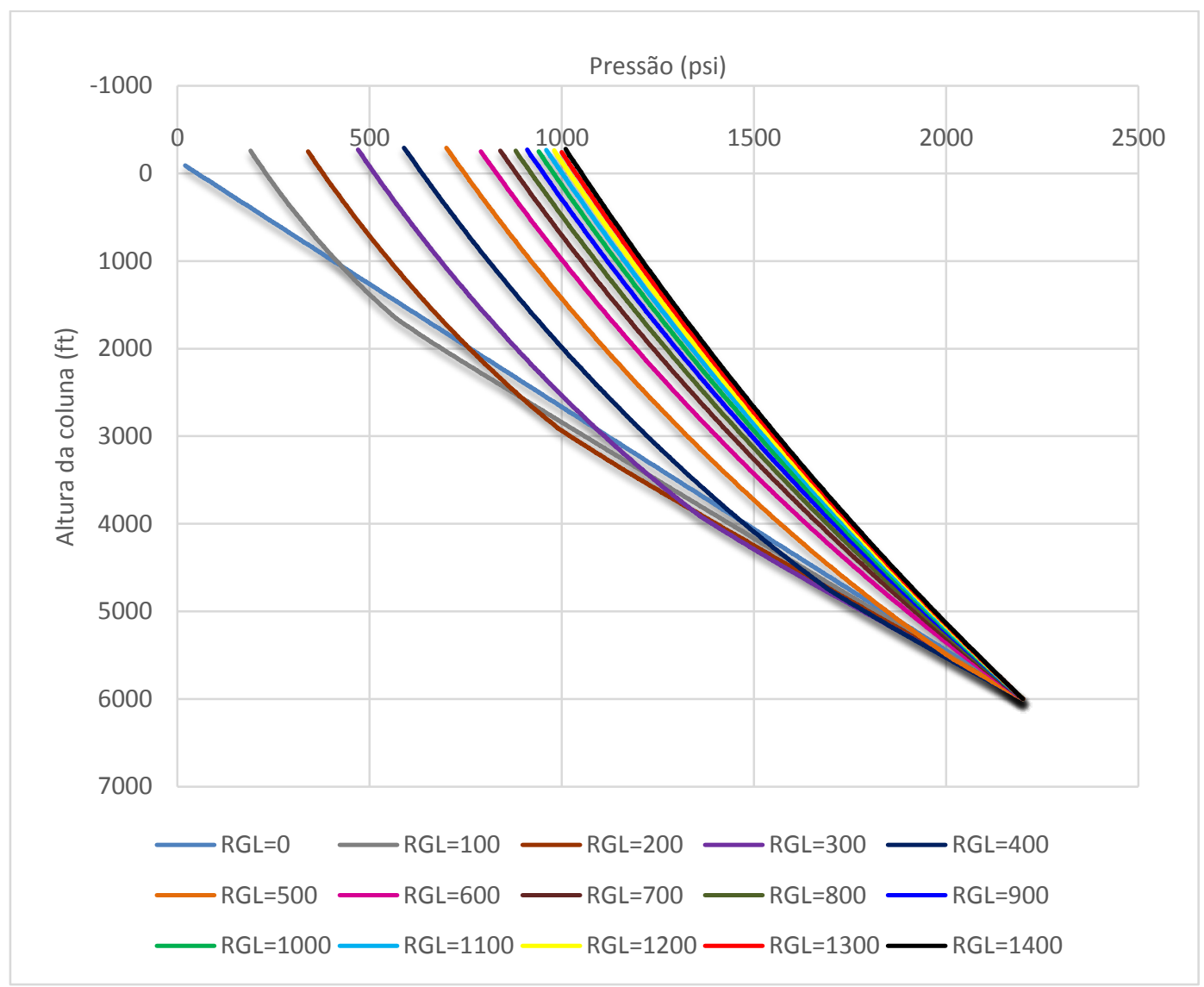

Figura 22 - Curvas obtidas para as condições da Tabela 6, com a versão 2 do programa

A pressão na cabeça do poço pode ser determinada através das curvas mostradas na Figura 22. Os cálculos são feitos partindo-se de $\mathrm{H}=$ profundidade da coluna até $\mathrm{H}=0$ (cabeça do poço). Logo, a pressão na cabeça do poço será a pressão quando $\mathrm{H}=0$. Por exemplo: de acordo com as curvas apresentadas na Figura 22, para RGL=100 scf/STB, $\mathrm{p}_{\mathrm{t}}$ será 230 psi, que é onde a curva de $\mathrm{RGL}=100$ corta a linha de $\mathrm{H}=0$. Já para $\mathrm{RGL}=300 \mathrm{scf} / \mathrm{STB}$, a pressão na cabeça do poço será aproximadamente 500 psi. 


\section{5 \\ Conclusão}

Nesta pesquisa é apresentado o desenvolvimento de um simulador de escoamento multifásico para poços verticais de produção de petróleo.

O simulador foi validado com dados da literatura técnica na área. A comparação com dados experimentais foi satisfatória. Os resultados foram compatíveis tanto em valores quanto em tendências.

Através do simulador, é possível determinar a pressão no fundo do poço em fluxo, dadas a pressão na cabeça e a profundidade do poço.

Inversamente, também é possível determinar a pressão na cabeça do poço, dadas a pressão no fundo do poço em fluxo e a profundidade do poço.

O simulador é aplicável na determinação da razão gás-líquido (RGL) ótima em instalações de elevação artificial por gás lift contínuo. Esta informação é usada para calcular a vazão ótima de injeção de gás neste processo.

O simulador é aplicável na determinação do perfil de pressões ao longo da coluna de produção, desenhando a curva de TPR (Tubing Performance Relationship). Da interseção desta curva com a de IPR (Inflow Performance Relationship) obtém-se a vazão real de produção.

Os estudos realizados mostram que quanto maior o diâmetro, maior a vazão de produção, para diâmetros internos da coluna entre 1,5 e 3,5 polegadas.

As curvas de gradiente de pressão geradas mostram que a pressão cresce com a profundidade, como deve ser.

As concavidades das curvas de gradiente de pressão foram para cima.

No caso da RGL, a influência na vazão de produção não é monotônica, sendo necessário executar simulações para cada conjunto de dados, a fim de estudar a RGL ótima.

Dos resultados obtidos, observou-se que, quanto maior a pressão do reservatório, maior era a vazão de produção, como esperado.

O simulador pode ser usado em projetos de poços para dimensionar a coluna de produção e o sistema de injeção de gás lift. 
Sugestão para trabalhos futuros: implementar correlações válidas para fluidos não newtonianos e regime transiente, estender a aplicação para poços inclinados, utilizar correlações do tipo 3 e estudar a troca de calor. 


\section{6 Referências Bibliográficas}

BAXENDELL, P. B.; THOMAS, R. (1961). The calculation of pressure 76radientes in high-rate flowing wells. J. Petrol. Technol., 18 (10):1023.

BENDIKSEN, K. H.; MALNES, D.; MOE, R.; NULAND, S. (1991). The Dynamic Two-Fluid Model Olga: Theory and Application. SPE (Society of Petroleum Engineers) Production Engineering, v 6:2, United States.

BRENNEN, C. E. (2005). Fundamentals of Multihase Flow. Cambrige University Press, Califórnia.

BRILL, J. P.; MUKHERJEE H. (1999). Multiphase Flow in Wells. $1^{\text {st }}$ ed. Texas.

CHEN, N.H. (1979). An Explicit Equation for Friction Factor in Pipe. Ind. Eng. Chem. Fundamen., 18 (3).

COLUMBIA http://civil.columbia.edu/engineering-mechanics (acessado em 26/11/2014)

COSTA e SILVA, C. B.; BORGES FILHO, M. J.; PINHEIRO, J. A. (2000). Medição de Vazão e Propriedades em Escoamento Multifásico: Solução Econômica para Diferentes Atividades Industriais. Boletim Técnico PETROBRAS, Rio de Janeiro, 43 (1): 45-61, jan/mar.

DANIELSON, T. J.; BROWN, L. D.; BANSAL, K.M. (2000). Flow Management: Steady-State and Transient Multiphase Pipeline Simulation. Offshore Technology Conference, Texas. 
DREUX, M. A.; AZEVEDO, F. U. B. (2009). Macros para excel na prática. Elsevier, Rio de Janeiro, Brasil.

ECONOMIDES, M. J.; HILL, A. D.; ECONOMIDES, C. E. (1994). Petroleum Production Systems. Ed. Prentice Hall.

GILBERT, W.E. (1954). "Flowing and Gas-lift Well Performance".

GOULD, T. L.;TEK, M. R. (1970). Steady and Unsteady State Two-Fhase Flow Throught Vertical Flow Strings.

GUO, B.; LYONS, W. C.; GHALAMBOR, A. (2007). Petroleum Production Engineering. Elsevier Science and Technology Books.

GRIFFITH, P.; WALLIS, G. B. (1961). Two-Phase Slug Flow. ASME J. Heat Transfer, 83.

GRYZLOV, A. N. (2011). Model-based estimation of multi-phase flow in horizontal wells.

HAGEDORN, A. R.; BROWN, A. E. (1965). Experimental Study of Pressure Gradients Occurring During Continuous Two-Phase Flow in Small-Diameter Vertical Conduits. Jornal of Petroleum Technology.

LYONS, W. C.; PILSGRA, G. J. (2005). Standard handbook of petroleum and natural gas engineering. 2 nd ed.

MAHMUDI, M.; SADEGHI, M. T. (2013). Performance Analysis of Compositional and Modified Black-Oil Models For a Gas Lift Process. Oil \& Gas Science and Technology - Rev. IFP Energy Nouvelles, vol. 68, no 2, pp 319-330. 
NASCIMENTO, J. C. S. (2013). Simulador de Escoamento Multifásico em Poços de Petróleo (SEMPP). Dissertação de mestrado, Universidade Federal do Rio Grande do Norte, Natal.

OLIVEIRA, M. F. D. (2003). Análise da aplicação de um sistema de bombeamento multifásico submarino na produção de petróleo. Dissertação de mestrado, Rio de Janeiro.

PIPESIM Suite - User Guide, copyright 1998 - 2009 Schlumberger. All rights reserved.

ROMAN, R.V.; HERNÁNDEZ, P. P. (2005). A new approach for continuous gas lift simulation and optimization. México, 2005.

SOUZA, J. N. M. (2010). Modelagem e Simulação de Escoameno Multifásico em Dutos de Produção de Óleo e Gás Natural. Tese de doutorado, UFRJ, Rio de Janeiro.

SZILAS, A. P. (1975). Production and Transport of Oil and Gas. ed. Elsevier, Budapest.

STANFORD http://me.stanford.edu/research/research-theme-computationalengineering (acessado em 26/11/2014)

VILLELA, M. J. R. Análise do Comportamento da Temperatura em Sistemas de Produção de Petróleo: Comparação entre Completação Seca e Molhada. Dissertação de mestrado, PUC, Rio de Janeiro. 


\title{
ANEXO A - ROTINA PRINCIPAL
}

\section{DESENVOLVIDA EM VBA}

\author{
Sub principal() \\ ' apagando dados do gráfico anterior:

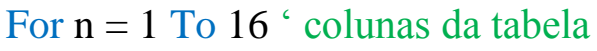 \\ For $\mathrm{m}=71$ To 500 ' linhas da tabela \\ Cells $(\mathrm{m}, \mathrm{n})=$ “" ' apaga todas as células \\ Next $m$ \\ Next $n$
}

'obtenção dos dados da planilha:

Qliq = Cells $(5,3)$ 'vazão de líquido em STB/dia

$\mathrm{fw}=\operatorname{Cells}(18,3)$ 'fração de água na fase líquida

$\mathrm{d}=\operatorname{Cells}(6,3)$ 'diâmetro em in

$\mathrm{e}=\operatorname{Cells}(7,3)$ 'rugosidade $\mathrm{em}$ in

gg $=\operatorname{Cells}(8,3)$ 'densidade do gás (gravidade específica), adimensional

gAPI $=$ Cells $(9,3)$ 'grau API do óleo

Tres $=$ Cells $(11,3){ }^{6}$ temperatura, ${ }^{\circ} \mathrm{F}$, nas condições iniciais do problema

$\mathrm{Pt}=\operatorname{Cells}(12,3)$ 'pressão na cabeça do poço, psia

$\mathrm{H}=$ Cells $(13,3)$ 'profundidade da coluna, $\mathrm{ft}$

lin $=\operatorname{Cells}(17,3)$ 'linha correspondente à vazão para que o programa 'imprima na linha correta da tabela, a informação de $\mathrm{P}_{\mathrm{wf}}$ para cada RGL. 'Essas 'tabelas são utilizadas para a construção das curvas de TPR

'Cálculos preliminares:

ed $=\mathrm{e} / \mathrm{d}$ 'Cálculo da rugosidade relativa, adimensional

$\mathrm{Qw}=\mathrm{fw}$ * Qliq "vazão de água no "stock tank” (na superfície), STB/dia

'STB/dia

go $=141.5 /(131.5+$ gAPI $)$ 'densidade relativa do óleo, adimensional 


\begin{abstract}
$\mathrm{A}=3.1415926 * \mathrm{~d}^{\wedge} 2$ / 4 'área transversal da coluna, in ${ }^{2}$
$\mathrm{dp}=\operatorname{Cells}(14,3)$ 'passo na pressão

$\mathrm{c}=26^{\text {' }}$ parâmetro para guiar o programa sobre em qual coluna se localiza a 'tabela onde deve imprimir a pressão obtida no final do loop $\left(\mathrm{P}_{\mathrm{wf}}\right)$ para 'efeito de obtenção da TPR.
\end{abstract}

' perda de carga total por unidade de comprimento:

For colu $=2$ To 16 'colunas correspondentes aos RGLs. Ex: Coluna 2, 'RGL=100; Coluna 3, RGL=200, etc.

hb $=0$ 'Altura inicial. Começa os cálculos de $\mathrm{H}_{\text {colu }}=0$

$\mathrm{PB}=\mathrm{Pt}$ 'Pressão na cabeça do poço(flowing tubing head pressure)

$\mathrm{i}=71$ 'primeira linha da tabela onde serão impressas as pressões e 'alturas correspondente para cada célula.

Cont = 0 'número de iterações, inicialmente igual a zero.

$\mathrm{T}=$ Tres 'Temperatura nas condições inicias do problema, ou seja, em ' $\mathrm{H}=0$

$\mathrm{RGL}=100 *($ colu -2$){ }^{`} \mathrm{RGL}$ variando de zero a 1400 com passo de 100. Essa RGL é a soma da RGL compreende o gás existente no poço e o gás proveniente do gas lift. Considerando a válvula alocada no fundo da coluna.

Do While (hb <= H + 300) 'critério de parada. Ultrapassa-se a altura da 'coluna porque, apesar do o interesse ser saber as condições em $h b=\mathrm{H}_{\text {colu }}$, 'na maioria dos casos, em um passo hb é menor que $\mathrm{H}_{\text {colu }}$ e no passo 'seguinte hb é maior e dessa forma é possível interpolar os resultados para ' $\mathrm{hb}=\mathrm{H}_{\mathrm{colu}}$

cont $=$ cont +1 'atualização do número de iterações

Cells $(65,17)=$ cont 'imprime o número de iterações na planilha

Cells $(\mathrm{i}, 1)=\mathrm{PB}$ 'imprime a pressão, psi, na tabela (o primeiro valor de 'pressão da tabela, será $\mathrm{Pt}$ )

Cells $(\mathrm{i}$, colu $)=\mathrm{hb}$ 'imprime a altura, ft, correspondente à pressão ( o 'primeiro valor de altura da tabela, será a altura correspondente à Pt, ou seja, 'zero) 


$$
\begin{aligned}
& \mathrm{pA}=\mathrm{PB} \\
& \mathrm{PB}=\mathrm{pA}+\mathrm{dp} \text { 'incremento na pressão, psi } \\
& \mathrm{Pm}=(\mathrm{pA}+\mathrm{PB}) / 2 \text { 'pressão média da célula, que será utilizada no } \\
& \text { 'cálculo das propriedades }
\end{aligned}
$$

Rsb = RGL / (1 - fw) " Razão de solubilidade do gás no óleo na pressão 'de bolha, scf/STBO

Pbolha = prebolha(gg, T, gAPI, Rsb) 'pressão de bolha, psia

Rs = Rsolu(gg, gAPI, Pbolha, Pm, T) 'razão de solubilidade do gás no 'óleo, scf/STB

Bo = fator_vol_de_formação(Rs, gAPI, gg, T, Pm, Pbolha) ' bbl/STB

mi_do = viscosidade_oleo_morto(T,gAPI) 'viscosidade do óleo morto, ${ }^{6} \mathrm{cP}$

mi_w $=1$ 'viscosidade da água, $\mathrm{cP}$

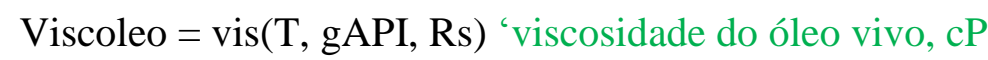

$\mathrm{Z}=\mathrm{Zgas}(\mathrm{gg}, \mathrm{Pm}, \mathrm{T})$ 'fator de compressibilidade do gás, adimensional mi_gas = viscgas $(\mathrm{gg}, \mathrm{Pm}, \mathrm{T})$ 'viscosidade do gás, $\mathrm{cP}$

$\mathrm{SIG}=81$ radie_superficial(Pm, T, gAPI) 'tensão superficial, dina/cm

$\mathrm{BG}=$ fator_vol_formacao_gas $(\mathrm{T}, \mathrm{Z}, \mathrm{Pm})$

Qgsc $=$ RGL * Qliq 'vazão de gás na superfície em scf/dia

$\mathrm{Ql}=(\mathrm{Qw}+$ Qost * Bo $) * 5.614$ / 86400 'vazão de líquido in situ, $\mathrm{ft}^{3} / \mathrm{s}$,

' (considerando presença de óleo e água)

vsl = Q1 / A * 144 'velocidade superficial de líquido, ft/s

$\mathrm{Qg}=(\mathrm{Qgsc}-$ Qost * Rs $) * \mathrm{BG} / 86400$ ‘vazão de gás, ft3/s

$\mathrm{vsg}=\mathrm{Qg} / \mathrm{A} * 144$ 'velocidade superficial do gás, ft/s

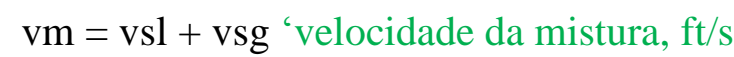

ro_oleo_morto $=$ go $* 62.4$ 'massa específica do óleo, Lbm/ft3

ro_gas_sc $=\mathrm{gg} * 0.0761$ 'massa específica do gás, Lbm/ft3

ro_liq $=($ ro_oleo_morto $*$ Qost + Rs * Qost * ro_gas_sc $+62.4 * \mathrm{Qw})$

/ (Bo* Qost + Qw) 'massa específica do líquido Lbm/ft3 
ro_oleo $=($ ro_oleo_morto + Rs * ro_gas_sc $) /$ Bo 'massa específica do óleo em $\mathrm{Lbm} / \mathrm{ft} 3$

ro_gas $=\mathrm{Pm} * \mathrm{gg} * 29 / \mathrm{Z} / 10.73 /(\mathrm{T}+460)$ 'massa específica do gás em Lbm/ft3

fw_linha $=\mathrm{Qw} /(\mathrm{Qw}+$ Qost * Bo $)$ 'fração de àgua in situ

mi_liq $=1^{\wedge} \mathrm{fw} \_$linha $*$ Viscoleo ${ }^{\wedge}\left(1-\mathrm{fw} \_\right.$linha $)$'viscosidade do 'líquido, cP

'cálculo dos números adimensionais do método de Hagedorn \& Brown:

N_vl $=$ Nvl(vsl, ro_liq, SIG)

N_vg $=\operatorname{Nvg}($ vsg, ro_liq, SIG)

N_d = Nd(d, ro_liq, SIG)

N_l = Nl(Viscoleo, ro_liq, SIG)

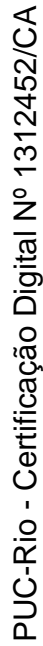

H_l = Hl(N_vl, N_vg, N_d, N_l, vsg, vm, Pm, d) 'holdup de líquido

$\mathrm{Hg}=1-\mathrm{H} \_$l 'holdup de gás

ro_mist $=$ ro_liq $* \mathrm{H} \_1+$ ro_gas $*$ Hg ' massa específica da mistura, 'Lbm/ft3

mi_mist $=\left(\right.$ mi_liq $\left.{ }^{\wedge} \mathrm{H} \_l\right) *\left(\right.$ mi_gas $\left.{ }^{\wedge} \mathrm{Hg}\right){ }^{`}$ viscosidade da mistura, $\mathrm{cP}$

$\operatorname{Re}=123.91 *(d * v m *$ ro_mist $) /$ mi_mist 'número de Reynolds

$\mathrm{f}=\mathrm{ffric}(\mathrm{Re}, \mathrm{ed})$ 'fator de fricção

dpdlfric $=\operatorname{dpdl}(\mathrm{d}, \mathrm{vm}$, ro_mist, $\mathrm{f}){ }^{\prime}$ perda de carga friccional, psi/ft

dpdlhid = ro_mist / 144 'perda de carga hidrostática, psi/ft

deltaH $=$ dp / (dpdlfric + dpdlhid $)$ 'nota-se que estamos desprezando a 'perda devido a energia cinética.

If $\mathrm{hb}>\mathrm{H}$ Then 'Se ultrapassar o comprimento da coluna: 
$\mathrm{x}=\mathrm{pA}+\mathrm{Abs}(\mathrm{dp}) *(\mathrm{H}-\mathrm{hb}) /(\mathrm{hb}+\mathrm{deltaH}-\mathrm{hb})$ 'interpolação para $\mathrm{P}$

' ( $\mathrm{x}$ ) correspondente a $\mathrm{H}$ exatamente igual a Hcolu, que é $\mathrm{P}_{\mathrm{wf}}$

Cells $($ lin, $\mathrm{c})=\mathrm{x}$ 'imprime $\mathrm{P}_{\mathrm{wf}}$ na posição da tabela correspondente para posterior construção das curvas de TPR

End If

$\mathrm{hb}=\mathrm{hb}+$ deltaH 'próxima célula

$\mathrm{T}=\mathrm{T}+0.01 *$ deltaH 'atualização da temperatura

$\mathrm{i}=\mathrm{i}+1$ 'atualização do contador

Loop

$\mathrm{c}=\mathrm{c}+4$

Next colu

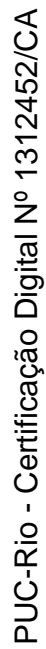

End Sub 


\section{ANEXO B - CURVAS DE}

\section{GILBERT}

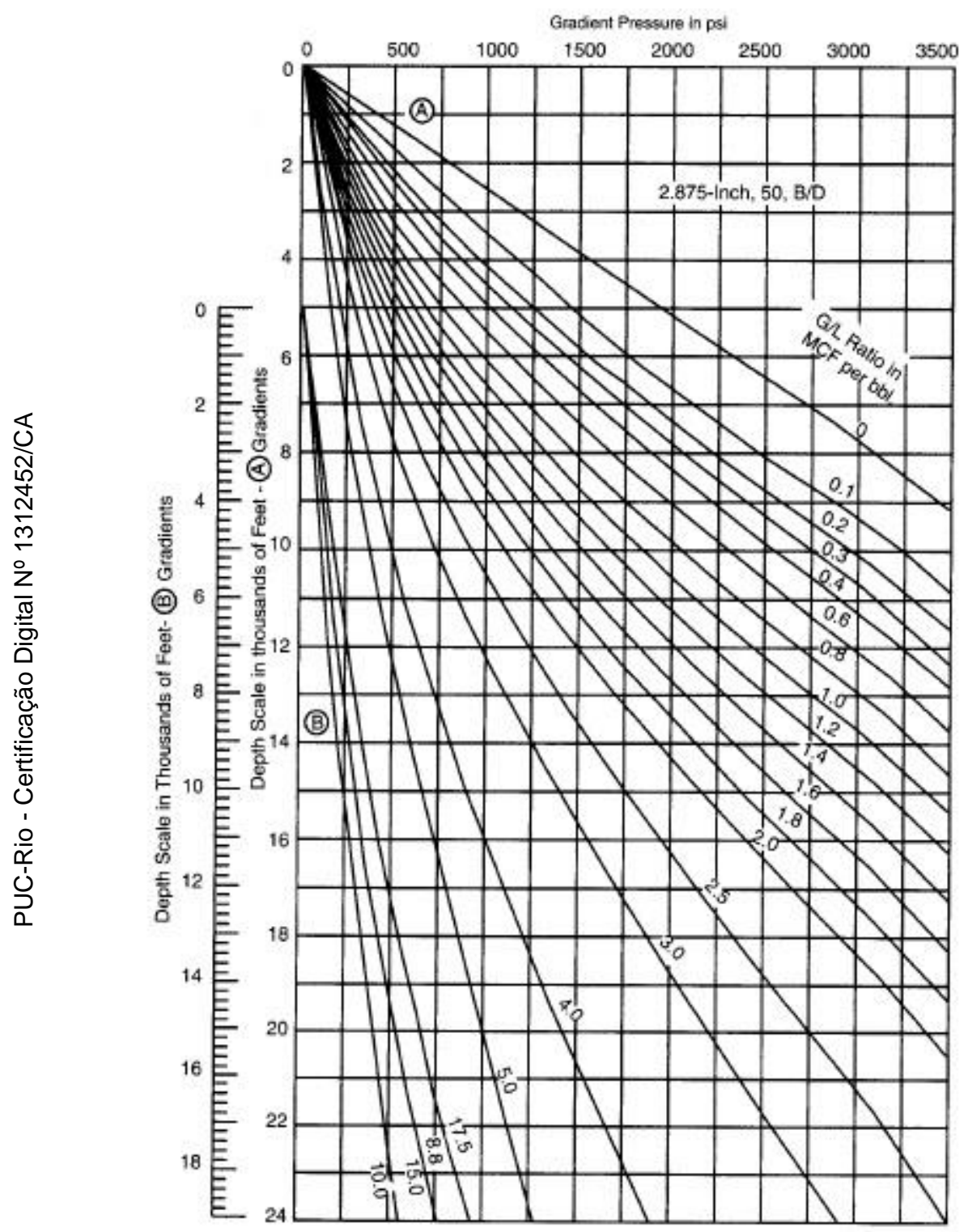

Figure 6.3.20 Flowing pressure gradients for 2.875 -in. tubing with rate of $50 \mathrm{bpd}$. 


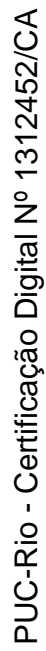

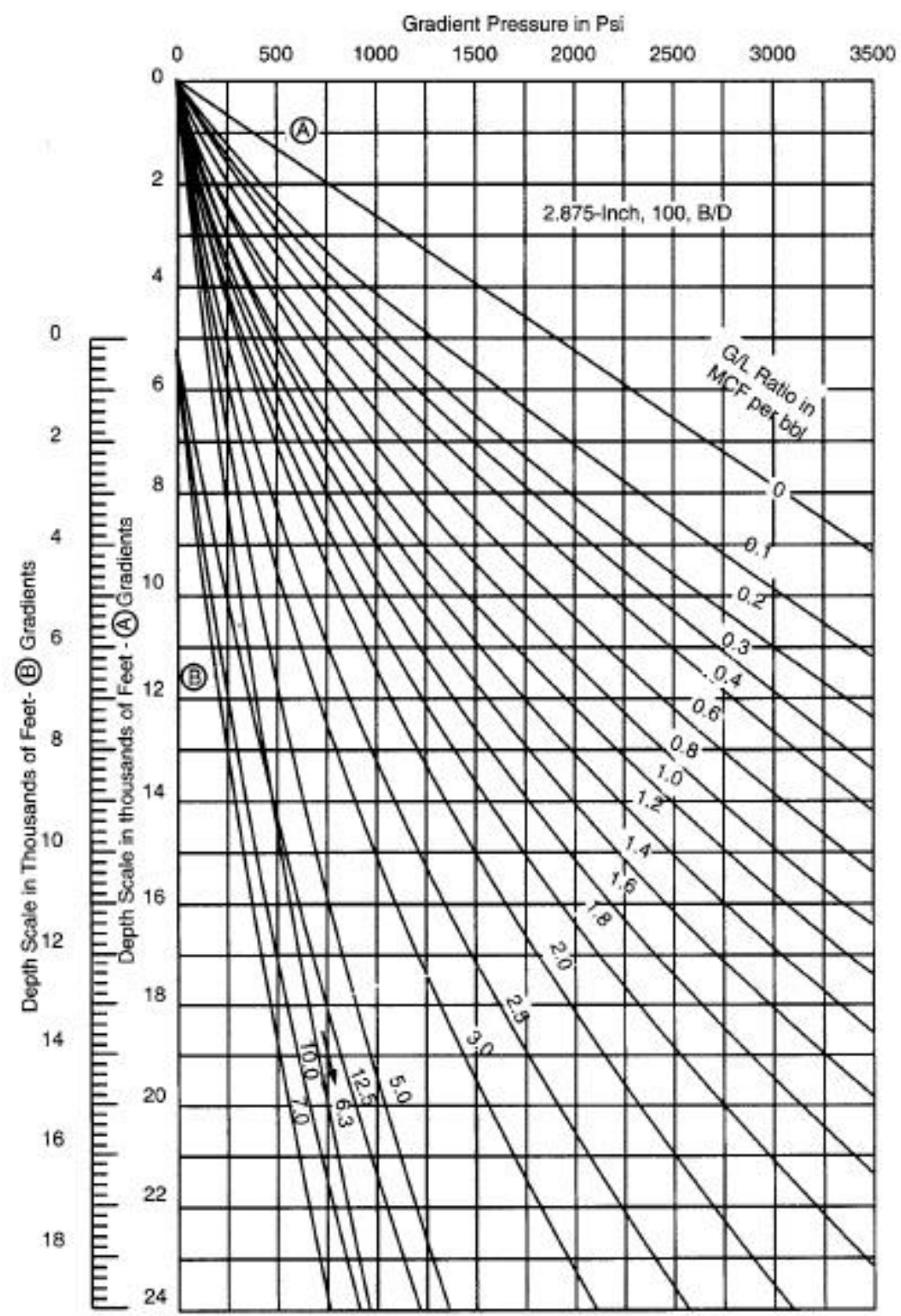

Figure 6.3.21 Flowing pressure gradients for 2.875-in. tubing with rate of $100 \mathrm{bpd}$. 


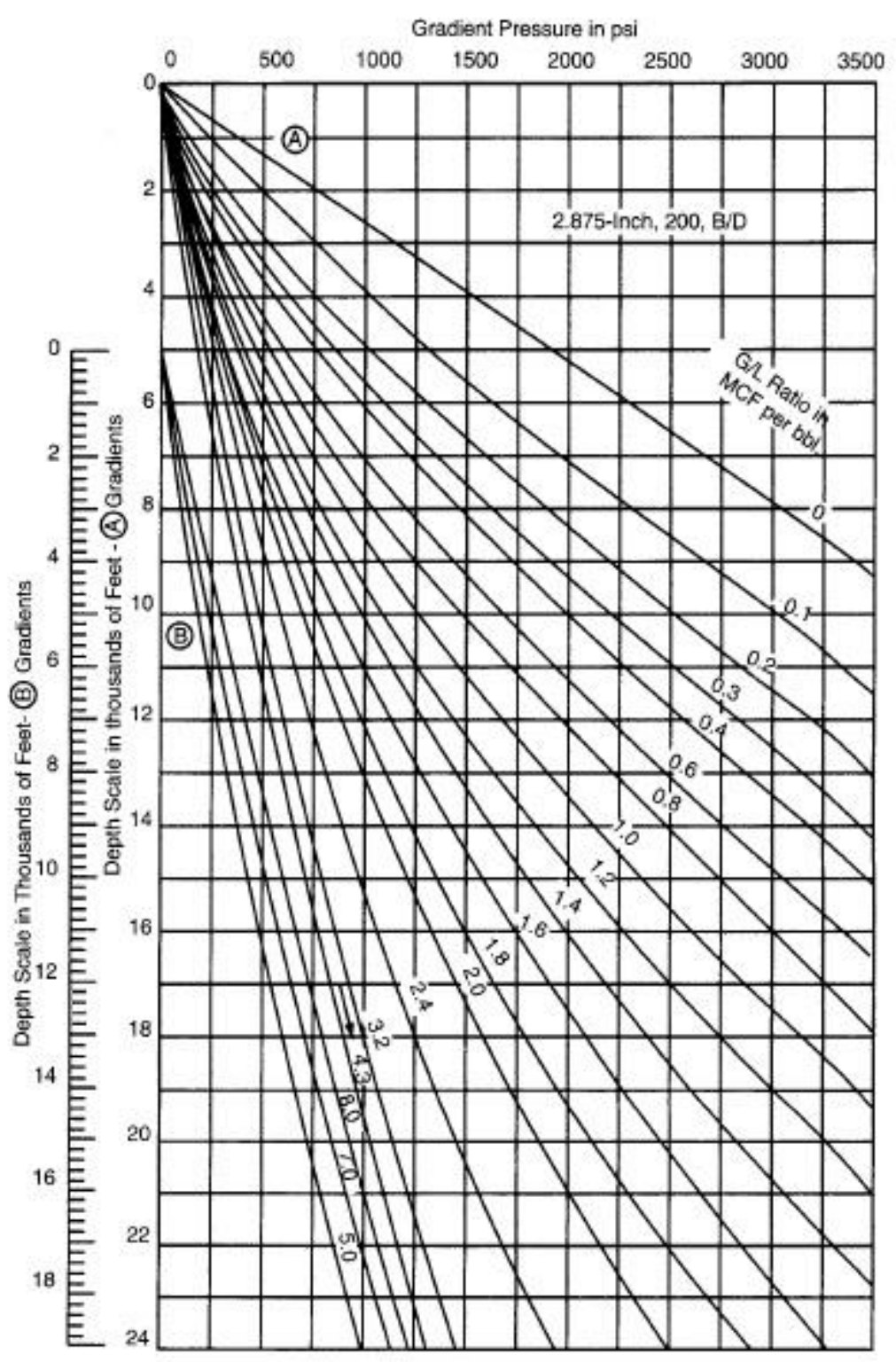

Figure 6.3.22 Flowing pressure gracients for 2.875 -in. tubing with rate of 200 bod. 


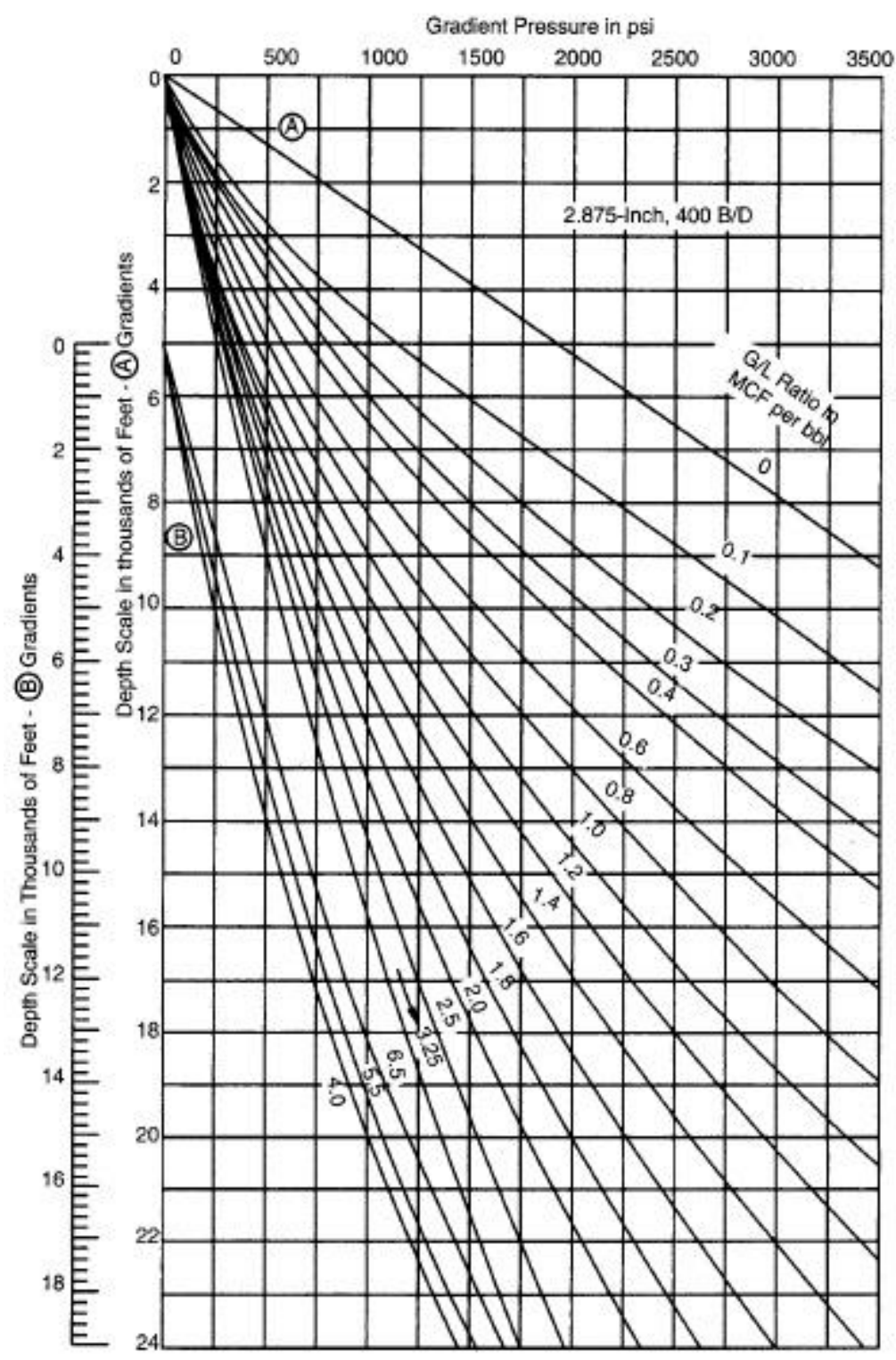

Figure 6.3.23 Fiowing pressure gradients for 2.875-in. tubing with rate of 400 bpd. 


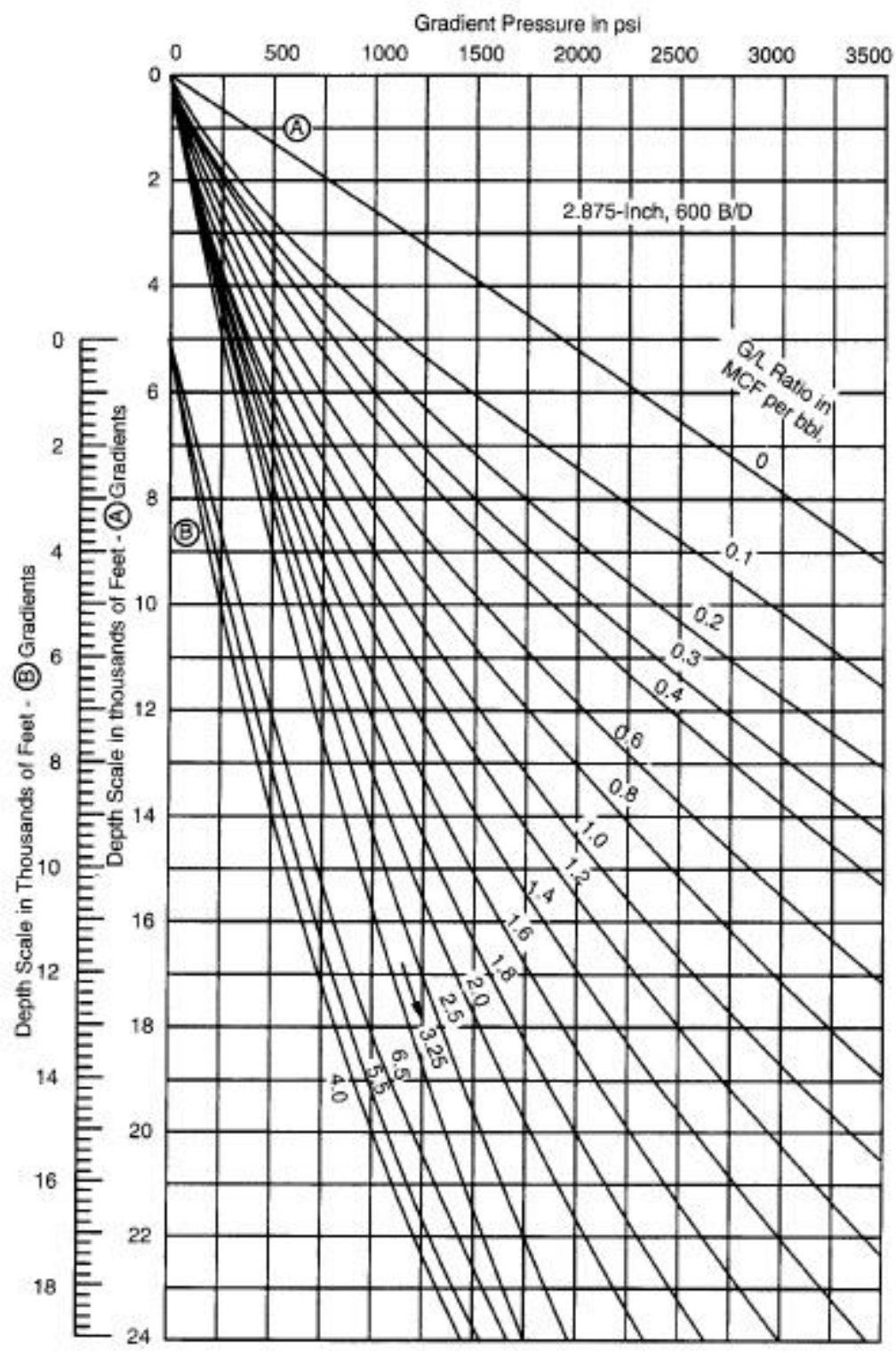

Figure 6.3.24 Flowing pressure gradients for 2.875 -in. fubing with rate of 600 bpo 


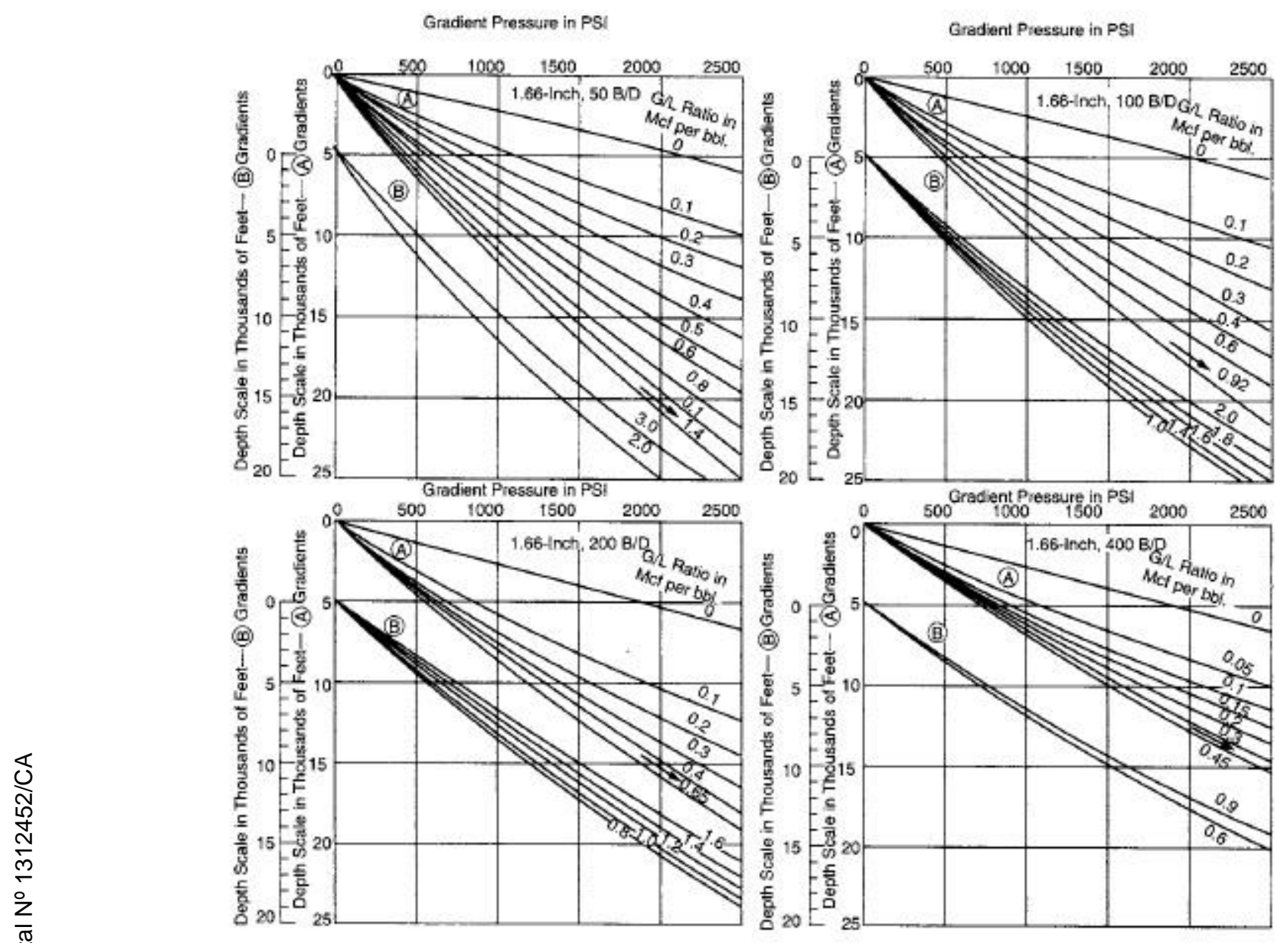

Figure 6.3.25 Flowing pressure gradients for 1.66-in. tubing with rate of $50-400 \mathrm{bpd}$. 

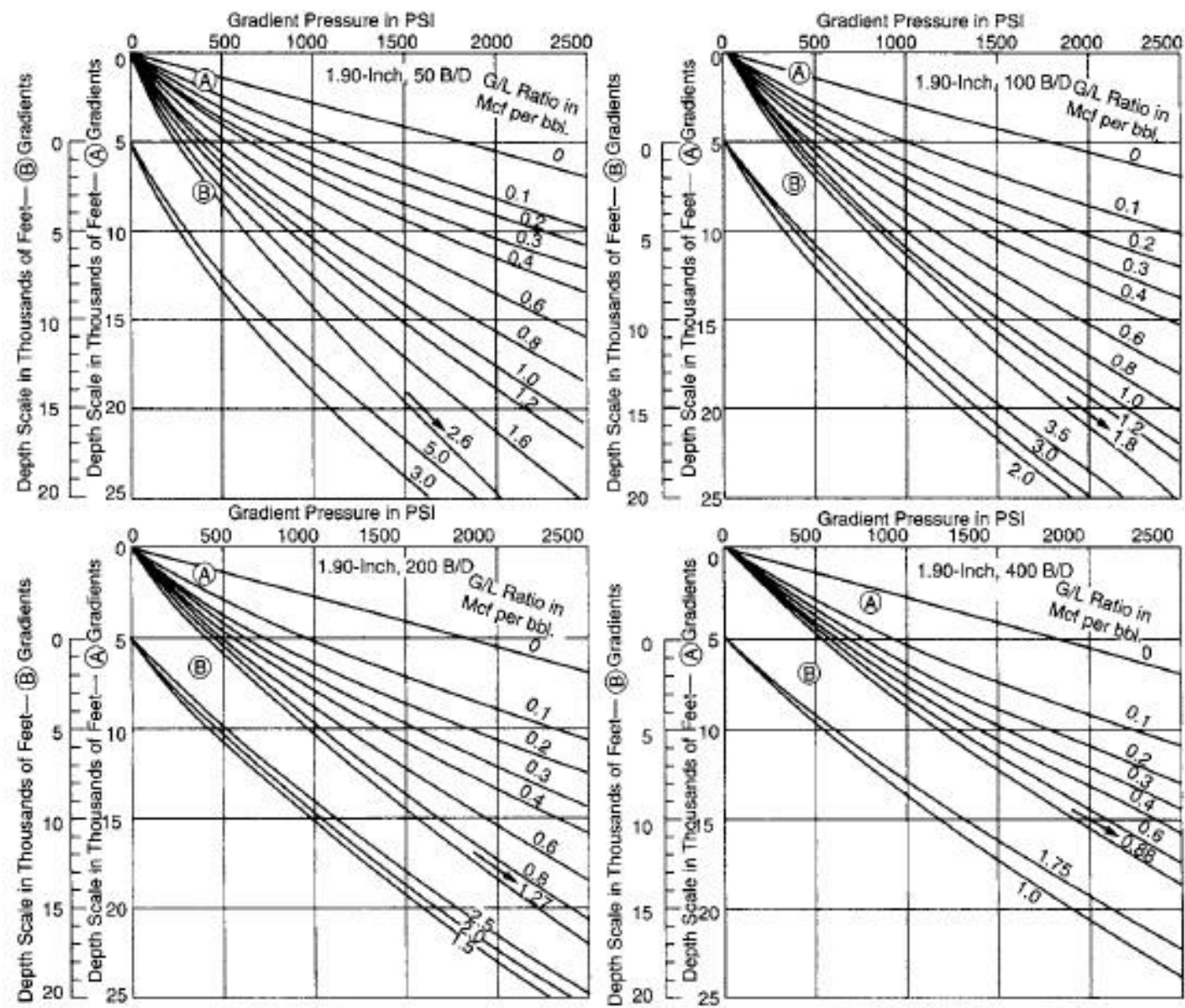

Figure 6.3.26 Flowing pressure gradients for 1.90-in. tubing with rate of 50-400 bpd. 


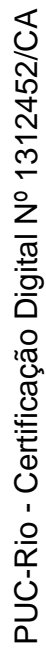

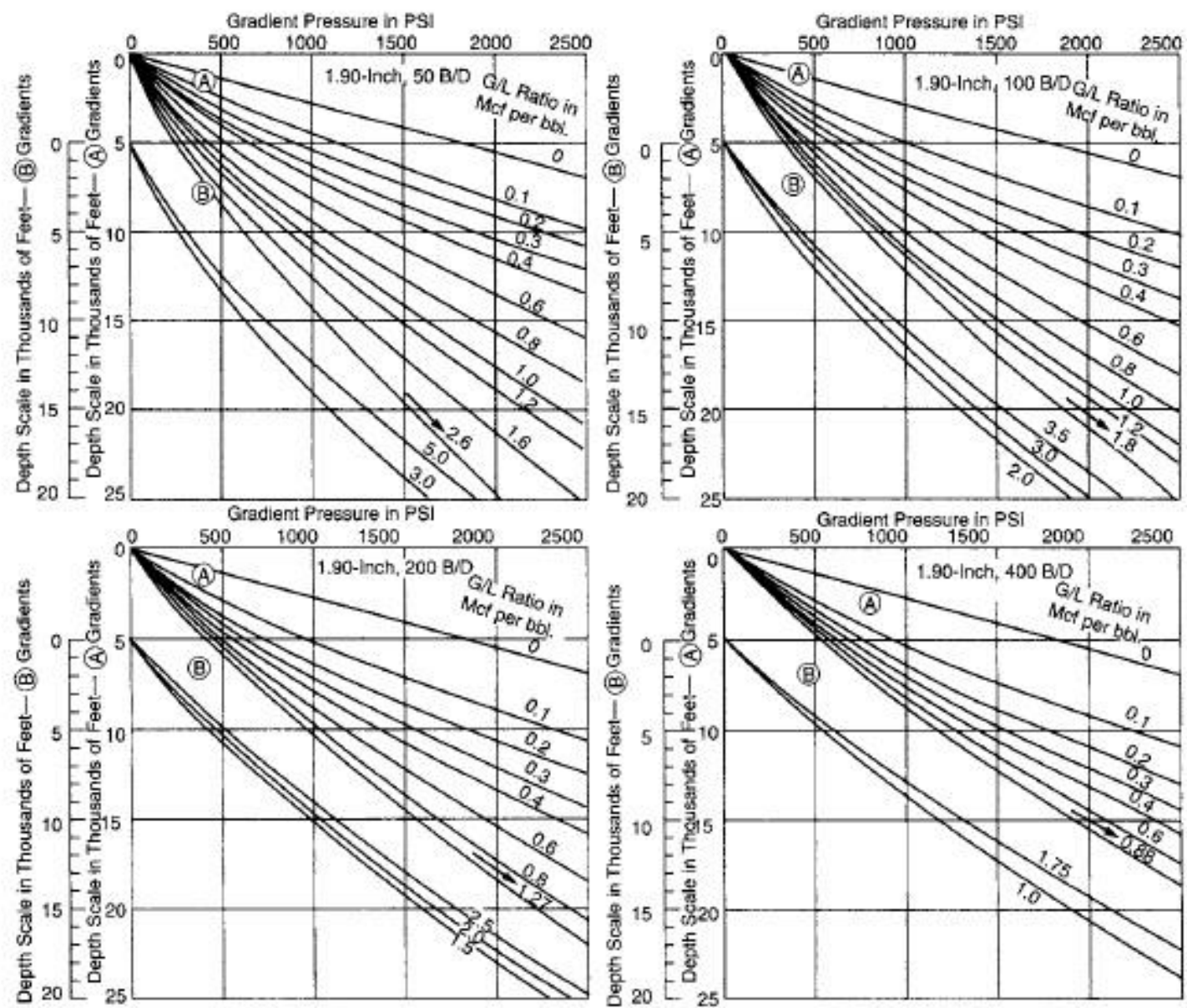

Figure 6.3.26 Flowing pressure gradients for 1.90-in. tubing with rate of 50-400 bpd. 


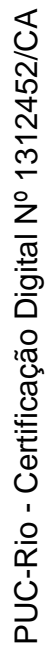
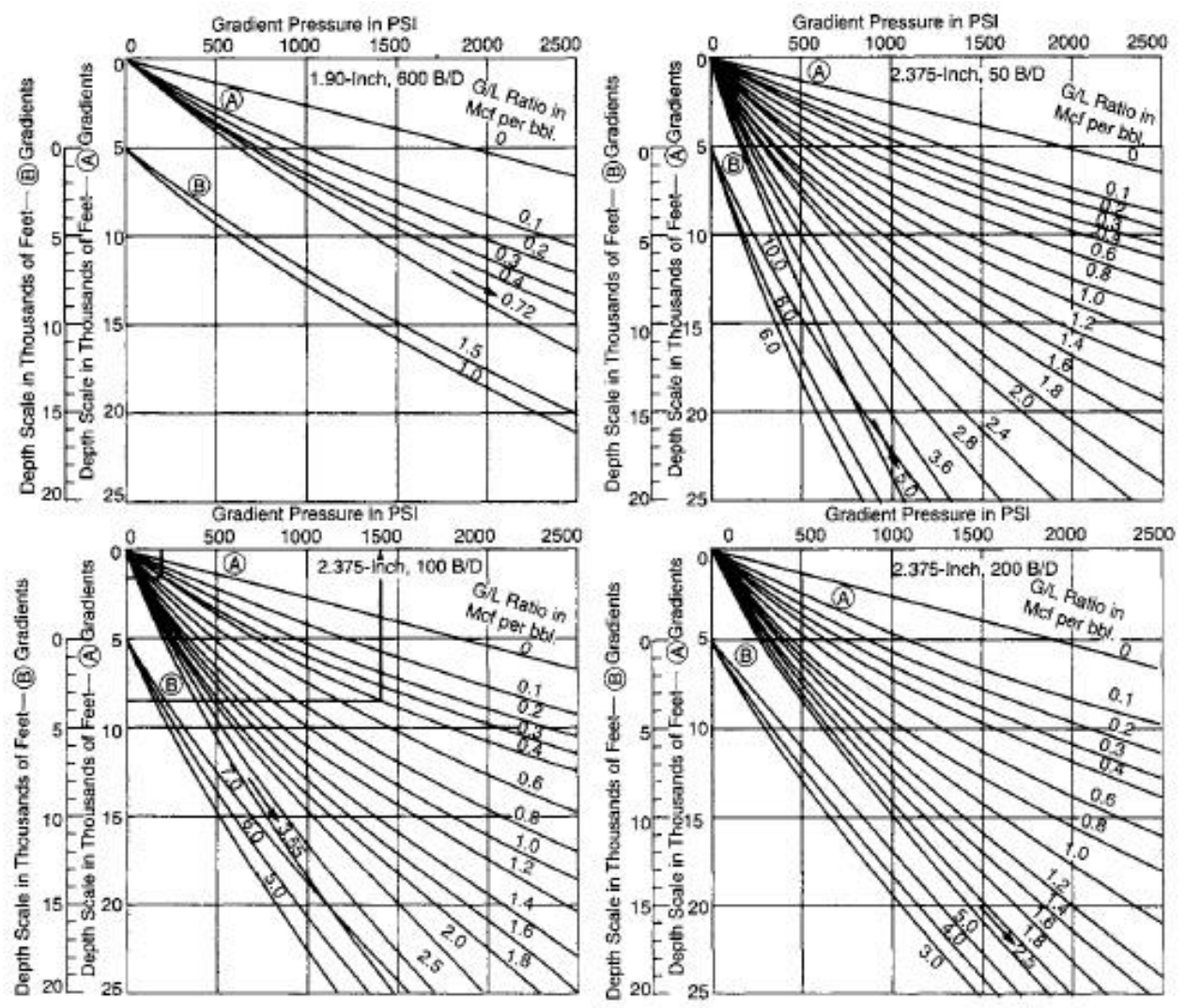

Figure 6.3.27 Flowing pressure gradients for 1.90-in. tubing with rate of 600 bpd and 2.375-in. tubing with rate of $50-200 \mathrm{bpd}$.
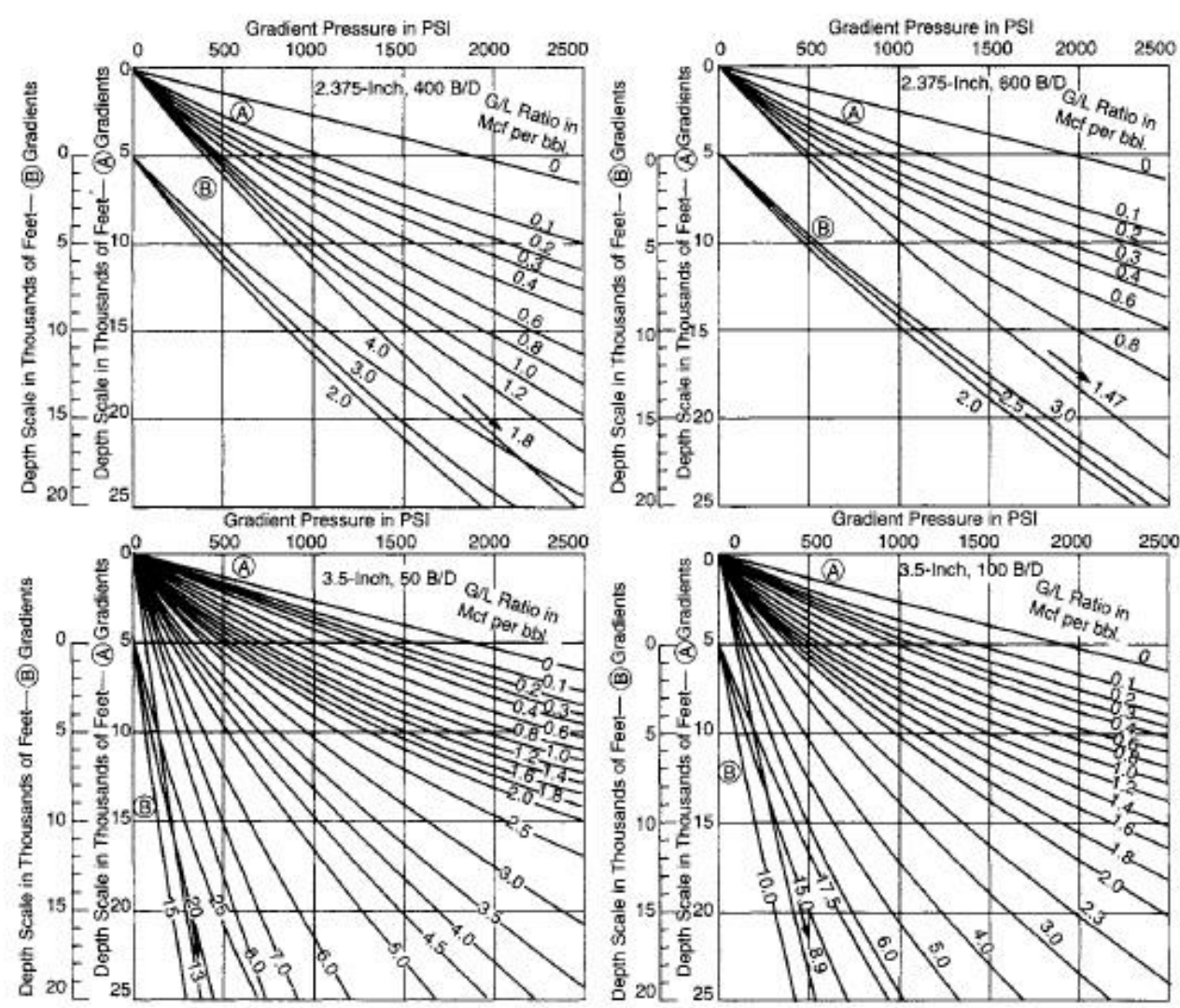

Figure 6.3.28 Flowing pressure gradients for 2.375-in. tubing with rate of $400-600$ bpd and 3.5-in. tubing with rate of $50-100 \mathrm{bpd}$. 


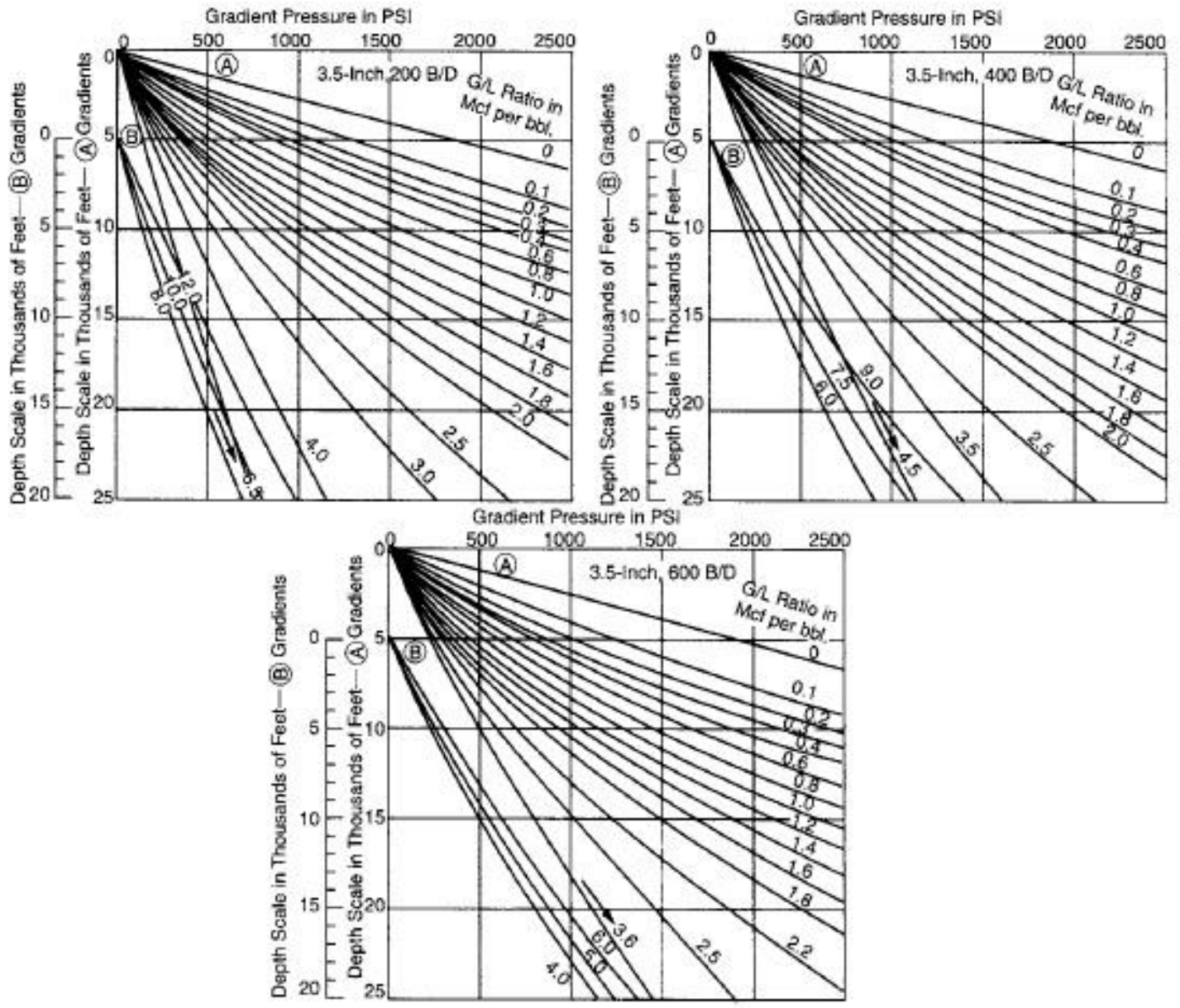

Figure 6.3.29 Flowing pressure gradients for 3.5-in. tubing with rate of $200-600 \mathrm{bpd}$. 